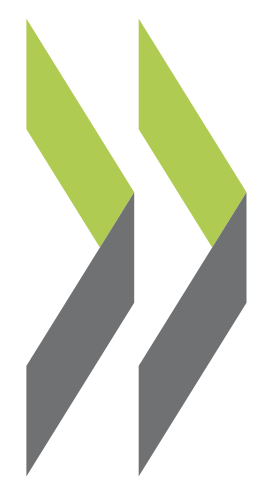

OECD Economics Department Working Papers No. 1076 Policies to support sustainable long-term Calista Cheung growth in New Zealand 


\section{Unclassified}

ECO/WKP(2013)68

Organisation de Coopération et de Développement Économiques

Organisation for Economic Co-operation and Development

08-Jul-2013

ECONOMICS DEPARTMENT

English - Or. English

POLICIES TO SUPPORT SUSTAINABLE LONG-TERM GROWTH IN NEW ZEALAND

ECONOMICS DEPARTMENT WORKING PAPERS No. 1076

By Calista Cheung

All Economics Department Working Papers are available through OECD's Internet website at http://www.oecd.org/eco/Workingpapers

JT03342841

Complete document available on OLIS in its original format

This document and any map included herein are without prejudice to the status of or sovereignty over any territory, to the delimitation of international frontiers and boundaries and to the name of any territory, city or area. 


\section{ABSTRACT/RÉSUMÉ}

\section{Policies to support sustainable long-term growth in New Zealand}

As its workforce ages and major economies shift towards producing higher value-added goods and services, New Zealand will face increasing challenges to remain globally competitive and maintain high living standards. Future growth will need to come increasingly from productivity gains, and resources will have to shift towards activities that rely more on skills, technology and intangible assets. Strengthening international linkages will be crucial to overcoming geographic disadvantages and will require improvements in the information and communications technology infrastructure, together with innovation leveraged off the country's strong primary industry knowledge base. Continuing to raise skill levels and the pensionable age will also help counter the effects of ageing. Lifting national saving, partly by targeting a higher public saving rate, will reduce the persistently high relative real interest rates and the sustained overvaluation of the real exchange rate, which potentially harm economic activity. To improve the sustainability of growth, revenues from non-renewable resource extraction need to be invested for the benefit of future generations and greater efforts devoted to mitigate the damage to natural capital from economic activity, particularly with respect to water quality. This Working Paper relates to the $2013 O E C D$ Economic Review of New Zealand (www.oecd.org/eco/surveys/New Zealand).

JEL classification codes: E24; E27; E61; E62; F10; F62; J11; J18; J24; J26; O43; O47; Q38; Q51; Q54; Q58

Keywords: growth; sustainable growth; comparative advantage; trade; distance; globalisation; product market regulation; innovation; human capital; migration; ageing; labour force participation; macroeconomic imbalances; net foreign assets; natural capital; green growth; climate change; royalties; emissions trading scheme

\section{Des politiques en faveur d'une croissance viable à long terme en Nouvelle-Zélande}

Tandis que sa population active vieillit et que les grandes économies s'orientent vers la production de biens et services apportant une plus grande valeur ajoutée, il va devenir de plus en plus difficile pour la Nouvelle-Zélande de rester compétitive sur la scène mondiale et de maintenir un niveau de vie élevé. À l'avenir, la croissance devra s'appuyer de plus en plus sur les gains de productivité, et les ressources devront être consacrées à des activités qui font davantage appel aux qualifications, aux technologies et aux actifs incorporels. Le renforcement des liaisons internationales, déterminant pour surmonter l'éloignement géographique, nécessitera une amélioration de l'infrastructure des technologies de l'information et de la communication, ainsi qu'une innovation tirant parti de la solide base de connaissances du pays dans le secteur primaire de l'économie. S'il continue à relever les niveaux de qualification ainsi que l'âge du départ à la retraite, le pays pourra compenser les effets du vieillissement de la population et, en visant un taux d'épargne publique plus élevée, il réduira les effets potentiellement néfastes de la lourde dette extérieure pour l'activité économique. Pour rendre la croissance plus durable, il devra investir les recettes de l'extraction des ressources non renouvelables au bénéfice des générations futures, et consacrer davantage d'efforts à l'atténuation des dommages qu'entraîne l'activité économique pour le capital naturel, et notamment la qualité de l'eau. Ce Document de travail se rapporte à l'Étude économique de l'OCDE de la Nouvelle-Zélande 2013 (www.oecd.org/eco/etudes/Nouvelle-Zélande).

Classification JEL : E24; E27; E61; E62; F10; F62; J11; J18; J24; J26; O43; O47; Q38; Q51; Q54; Q58

Mots clefs: croissance; croissance durable; avantages comparatifs; commerce; distance; mondialisation; réglementation des marchés de produits; innovation; capital humain; migration; vieillissement; taux d' activité de la main d'œuvre; déséquilibres macroéconomiques; position extérieure nette; capital naturel; croissance verte; changement climatique; redevances; système d'échange de quotas d'émissions multimedia products in your own documents, presentations, blogs, websites and teaching materials, provided that suitable acknowledgment of $\mathrm{OECD}$ as source and copyright owner is given. All requests for commercial use and translation rights should be submitted torights@oecd.org. 


\section{Table of contents}

Policies to support sustainable long-term growth in New Zealand ................................................ 5

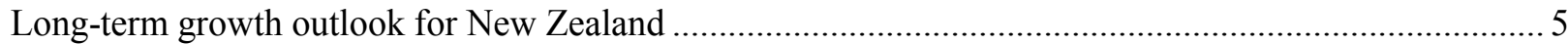

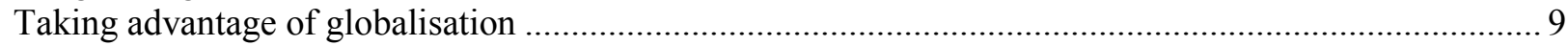

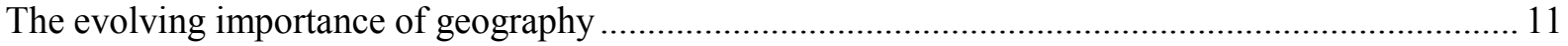

Factors shaping New Zealand's comparative advantage .................................................................. 13

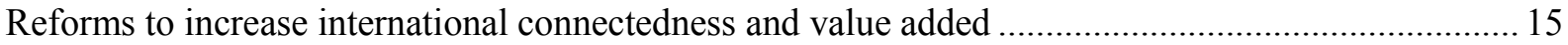

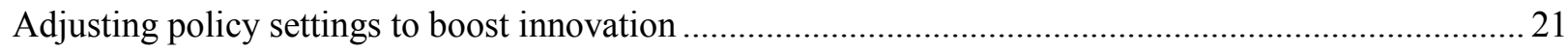

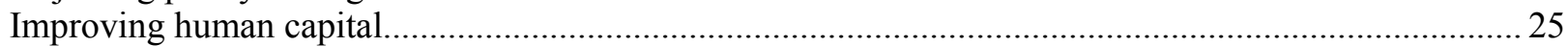

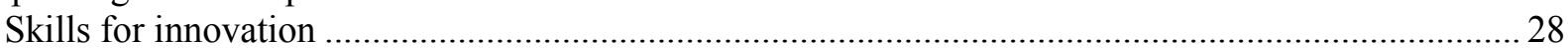

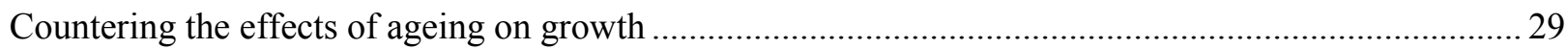

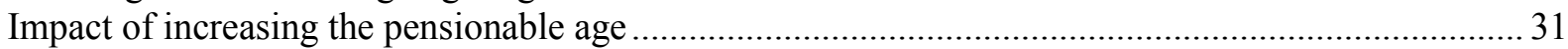

Correcting large macroeconomic imbalances that may harm long-term growth ................................... 31

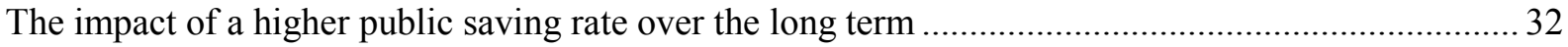

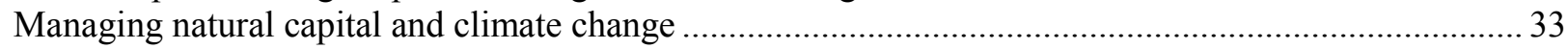

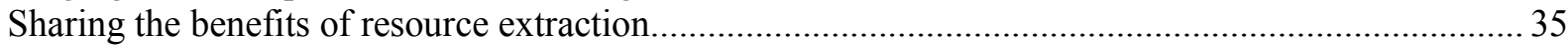

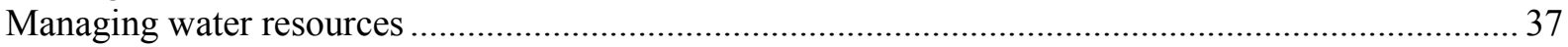

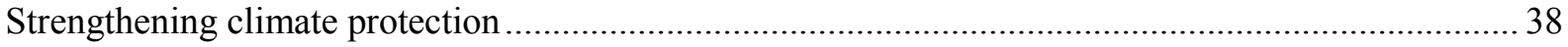

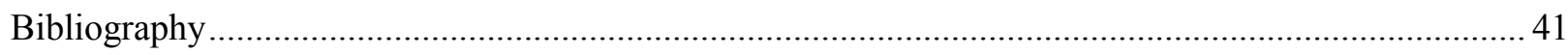

Annex 1 The relationship between net foreign assets and interest rates in New Zealand ....................... 48

\section{Boxes}

1. Model properties and assumptions underlying the long-term baseline scenario............................. 7

2. New Zealand's Technology Development Grants (TDGs) .........................................................25

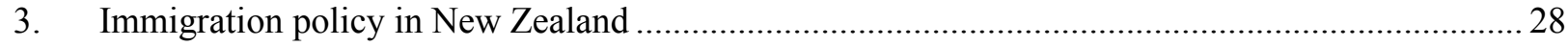

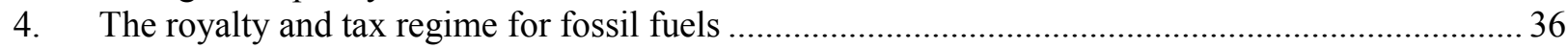

5. Policy recommendations to support sustainable long term growth............................................... 40

\section{Tables}

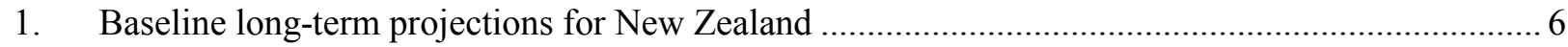

2. Migrant stock of persons born in Asia living in the OECD countries, 2005-06 .......................... 12

A1.1. Results from panel regressions on real long-term interest rates.................................................. 50 


\section{Figures}

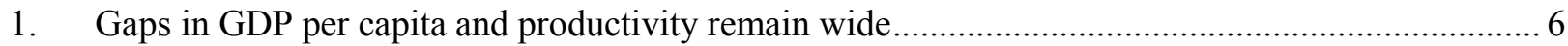

2. Contributions to growth in real GDP per capita in constant USD 2005 PPPs ............................... 7

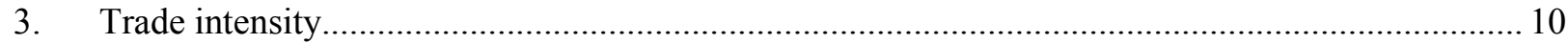

4. Global value chain participation index in OECD countries ...................................................... 10

5. International students from Asia (including Japan and Korea) in OECD countries ....................... 12

6. Triadic trademark applications at JPO, OHIM and USPTO, 2007-09 average ............................ 13

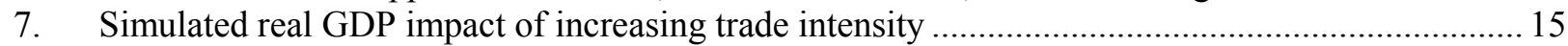

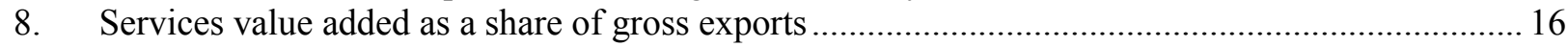

9. Participation and position in computer services global value chains ........................................... 17

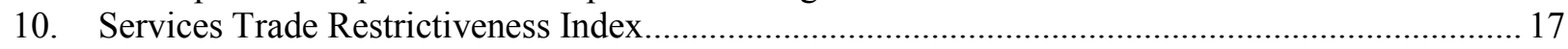

11. Average measured connection speeds by country.................................................................... 18

12. Range of broadband prices for a monthly subscription - including line charge ............................. 19

13. Projected real GDP impact of moving product market regulations to best practice ........................ 21

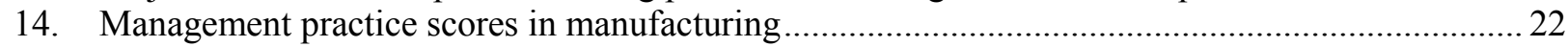

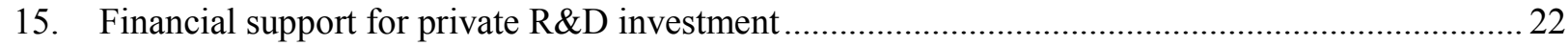

16. Revealed technological advantage in biotechnologies, 1998-2000 and 2008-10 .........................23

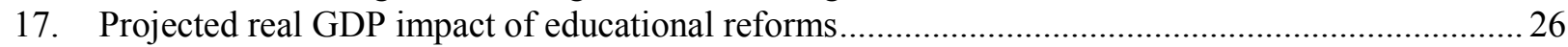

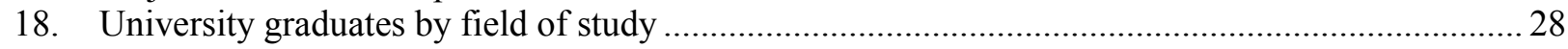

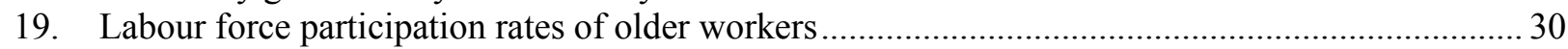

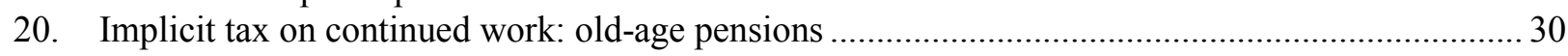

21. Projected impact of raising pensionable age in line with life expectancy..................................... 31

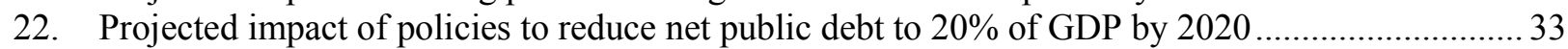

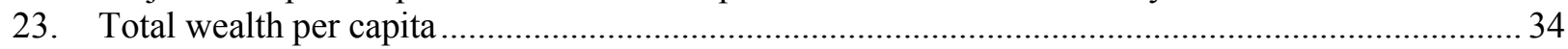

24. Productivity growth adjusted for natural capital and inputs and bad outputs ................................ 35

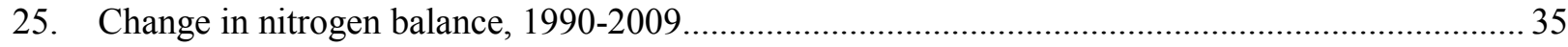

26. Average government take in oil and gas fiscal regimes............................................................. 36

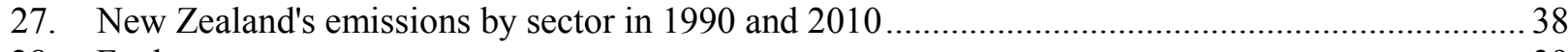

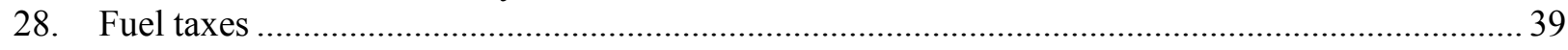

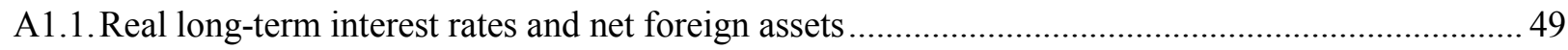

The statistical data for Israel are supplied by and under the responsibility of the relevant Israeli authorities. The use of such data by the OECD is without prejudice to the status of the Golan Heights, East Jerusalem and Israeli settlements in the West Bank under the terms of international law. 
ECO/WKP(2013)68

\title{
Policies to support sustainable long-term growth in New Zealand
}

\author{
By \\ Calista Cheung ${ }^{1}$
}

New Zealand's labour productivity levels and growth rates have long lagged those in other OECD countries, and globalisation and the changing patterns of world trade risk leaving it further behind unless structural reforms are undertaken to overcome its disadvantages as a small and remote economy. As demographic trends place downward pressure on growth prospects, future sources of prosperity will need to come increasingly from innovation and skills to shift the country's comparative advantages towards knowledge-intensive activities for which demand is less sensitive to distance. In addition, the sustainability of growth will depend on how efficiently it uses its abundant natural capital.

This paper discusses the various factors affecting New Zealand's future growth prospects and proposes policies to safeguard and improve long-term economic prosperity. A new long-term projection model for the OECD and major non-OECD economies, described in Johansson et al. (2013), is used to construct a baseline scenario for growth over the next 50 years as an underlying framework. The model is then used to explore the potential growth implications of various structural policy changes, including reforms that improve international trade linkages, product market regulations, labour force participation, human capital and national saving.

\section{Long-term growth outlook for New Zealand}

New Zealand's economy faces the complex challenge of shifting from a recent pattern of growth powered by private-sector borrowing and terms-of-trade gains towards more sustainable productivity increases. Since the early 1990s, high rates of labour utilisation have been a key driver of per capita income gains but are likely to diminish as the population ages. Overall living standards as measured by GDP per capita have been well below the OECD average over the last 20 years, with little sign of convergence (Figure 1). Decompositions of per capita GDP suggest that New Zealand's longstanding shortfall relative to other OECD countries reflects in large part poor multi-factor productivity (MFP) growth (OECD, 2011c). Capital intensity also appears comparatively weak, following consistently low shares of business investment in GDP since the 1960s.

1. OECD Economics Department; e-mail: calista.cheung@oecd.org. This paper was prepared for the OECD Economic Survey of New Zealand published in June 2013 under the authority of the Economic and Development Review Committee. The author is thankful to Alexandra Bibbee, Nils-Axel Braathen, Nicola Brandt, David Carey, Steven Clark, Andrew Dean, Augustin Diaz-Pines, Robert Ford, Nathalie Girouard, Yvan Guillemette, David Haugh, Gernot Hutschenreiter, Peter Jarrett, Asas Johansson, Przemyslaw Kowalski, Thomas Liebig, Josep Mestres, Annabelle Mourougane, Fabrice Murtin, Sam Paltridge, David Turner, Simon Upton, Rudolf van der Berg, and New Zealand government officials for their valuable comments and suggestions. Special thanks are due to Guillaume Bousquet, Françoise Correia, Francesca Spinelli for excellent statistical assistance, Nicola Brandt and Vera Zipperer for their work developing green productivity measures, and Mee-Lan Frank for technical preparation. 
Figure 1. Gaps in GDP per capita and productivity remain wide

Gap to the upper half of OECD countries ${ }^{1}$, per cent

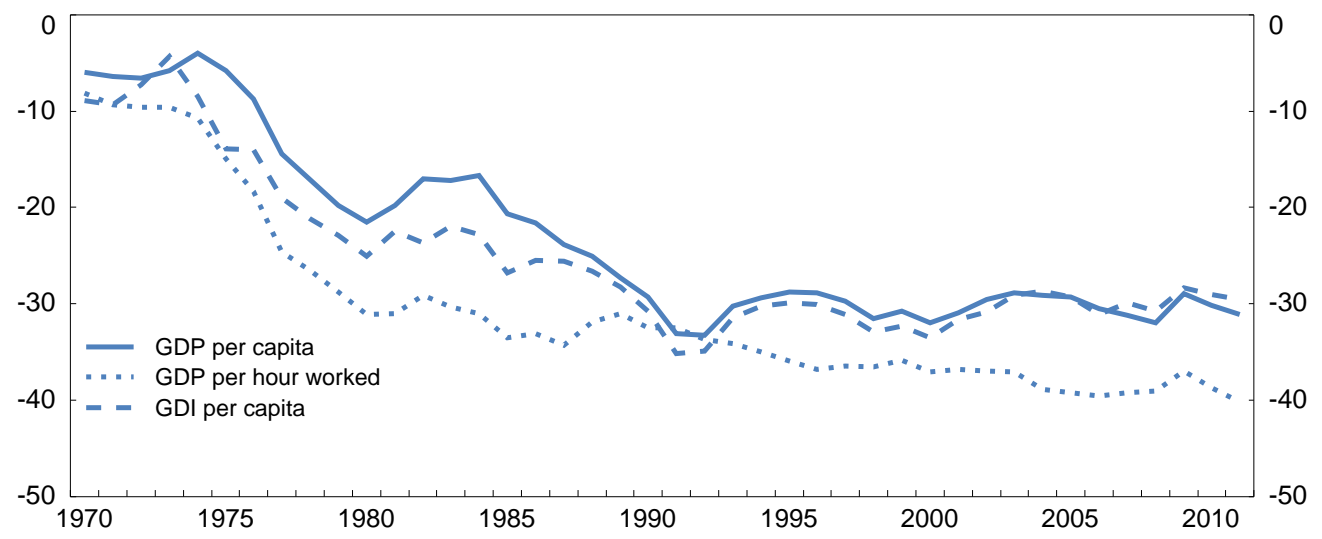

1. Percentage gap with respect to the simple average of the highest 17 OECD countries in terms of GDP per capita, GDP per hour worked and GDI per capita (in constant 2005 PPPs).

Source: OECD (2013), Economic Policy Reforms 2013: Going for Growth, OECD Publishing.

Using the OECD long-term projection model, a baseline scenario for economic growth in New Zealand is presented in Table 1, which assumes that all countries take appropriate policy actions to restore their economies to sustainable paths. The scenario suggests that annual potential output growth in New Zealand might stabilise at a rate of close to $2 \%$ over the long term, assuming no major structural policy changes. In the long run, projected increases in real income per capita will be driven mainly by multi factor productivity trends (MFP). As the population ages, labour input will begin to decline from around 2025 (Figure 2). These demographic changes could place downward pressure on national saving rates, and a substantial current account deficit may persist into the long term. These growth projections are

Table 1. Baseline long-term projections for New Zealand ${ }^{1}$

\begin{tabular}{|c|c|c|c|c|c|c|c|c|c|c|}
\hline & 2011 & 2012 & 2013 & 2014 & 2020 & 2025 & 2030 & 2040 & 2050 & 2060 \\
\hline Output growth (annual) & 0.5 & 1.6 & 2.4 & 2.9 & 2.7 & 2.6 & 2.4 & 2.3 & 2.1 & 1.9 \\
\hline Potential output growth (annual) & 1.4 & 1.5 & 1.7 & 1.9 & 2.7 & 2.6 & 2.4 & 2.3 & 2.1 & 1.9 \\
\hline $\begin{array}{l}\text { Potential labour productivity } \\
\text { growth (annual) }\end{array}$ & 0.4 & 0.5 & 0.6 & 0.8 & 1.7 & 1.8 & 1.9 & 1.9 & 1.9 & 1.8 \\
\hline $\begin{array}{l}\text { Trend multi-factor productivity } \\
\text { growth (annual) }\end{array}$ & -0.4 & -0.2 & 0.0 & 0.2 & 0.9 & 1.1 & 1.2 & 1.3 & 1.2 & 1.2 \\
\hline Potential employment growth & 1.0 & 1.1 & 1.1 & 1.1 & 1.0 & 0.7 & 0.5 & 0.4 & 0.2 & 0.1 \\
\hline $\begin{array}{l}\text { Trend labour force participation } \\
\text { rate }\end{array}$ & 67.5 & 67.5 & 67.5 & 67.5 & 67.2 & 66.6 & 65.6 & 64.2 & 64.0 & 63.2 \\
\hline Structural unemployment rate & 6.2 & 6.4 & 6.4 & 6.4 & 5.6 & 5.0 & 4.6 & 4.3 & 4.3 & 4.3 \\
\hline Fiscal blance (\% GDP) & -7.9 & -4.3 & -3.6 & -2.1 & -0.9 & -0.9 & -0.9 & -0.9 & -0.8 & -0.7 \\
\hline $\begin{array}{l}\text { Gross government debt (\% } \\
\text { GDP) }\end{array}$ & 48.3 & 51.3 & 54.3 & 55.6 & 55.9 & 56.1 & 56.3 & 56.6 & 56.9 & 56.8 \\
\hline Real long-term Interest rate & 2.8 & 0.7 & 1.4 & 2.4 & 3.0 & 3.3 & 3.3 & 3.7 & 3.6 & 3.5 \\
\hline Total national saving (\%GDP) & 14.6 & 15.0 & 15.8 & 16.5 & 16.6 & 15.5 & 14.3 & 12.5 & 12.2 & 11.4 \\
\hline Investment (\% GDP) & 18.7 & 20.8 & 22.0 & 22.7 & 21.5 & 20.4 & 19.6 & 17.8 & 16.6 & 15.4 \\
\hline Current account (\% GDP) & -4.1 & -5.5 & -5.9 & -5.9 & -4.6 & -4.7 & -5.1 & -5.2 & -4.4 & -4.0 \\
\hline $\begin{array}{l}\text { Real GDP per capita (USD } 2005 \\
\text { PPP) }\end{array}$ & 248254 & 249688 & 252971 & 257672 & 282830 & 30915 & 33803 & 40725 & 49139 & 58515 \\
\hline
\end{tabular}

1. Due to timing issues, the numbers reported here for 2011-2014 are taken from the OECD Economic Outlook 92 database. As a result, they differ from those presented earlier in Table 1 of the Assessment and Recommendations, which are based on the OECD Economic Outlook 93 database.

Source: OECD calculations. 
predicated on the economic theory of conditional convergence, whereby in the long run all countries eventually grow at the same rate determined by the pace of technical progress, but differences in institutional settings and capital/labour endowments create persistent gaps in living standards across countries (Box 1).

Figure 2. Contributions to growth in real GDP per capita in constant USD 2005 PPPs

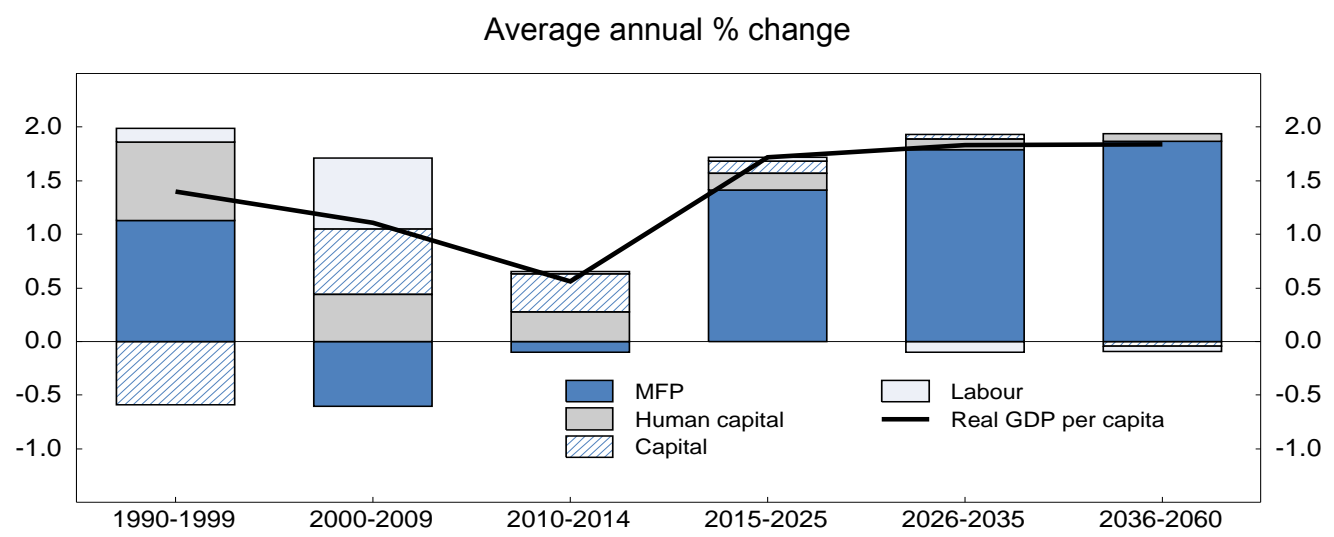

1. To ensure that the components add up to GDP per capita the decomposition is done in log differences since the decomposition is multiplicative. Annual growth in real GDP per capita is equal to the product of the components MFP, Human capital, (Physical capital/GDP)a/(1-a) (where a is the capital share in income) and the employment/population ratio. Nevertheless, because period averages for the components are shown here, they do not sum up exactly to the total.

Source: OECD calculations.

\section{Box 1. Model properties and assumptions underlying the long-term baseline scenario}

The baseline represents a stylised scenario anchored on the short-term economic projections from $O E C D$ Economic Outlook No. 92 for the 2012-14 horizon, beyond which real GDP converges towards potential output within five years. Potential output follows a Cobb-Douglas production function with constant returns to scale and with physical capital, human capital and labour as inputs plus technological progress in the form of multi-factor productivity (MFP) gains. MFP follows a conditional convergence process based on the framework of Bourlès et al. (2010) and Bouis et al. (2011), moving toward its own steady-state trajectory, which is determined by the worldwide rate of technical progress and country-specific structural settings, as captured in product market regulation indicators. Each country's speed of convergence depends on its absorption of international technology spillovers, as proxied by its trade intensity. Other factors that may influence productivity such as investment in R\&D or innovation are not explicitly taken into account in the model.

For most countries, current account balances are projected as the difference between saving and investment. Private saving rates are determined by demographic factors, fiscal balances, the terms of trade, availability of credit, productivity growth and net oil balances. Investment is backed out from projected capital stocks, whose evolution depends on the user cost of capital and historical capital-output ratios.

Long-term interest rates are determined by expected short-term interest rates, a fixed term premium and a fiscal-risk premium. The fiscal-risk premium increases by 2 basis points for every percentage point that public debt exceeds $75 \%$ of GDP and an additional 2 basis points for every percentage point that the public debt ratio exceeds $125 \%$, based on the findings of Égert (2010).

Labour force participation rates are projected using a cohort approach, which assumes that all future cohorts participate in the labour force at the same rates as the most recent cross-section of cohorts. Age-gender specific labour force participation rates are then aggregated using relative population weights of each cohort, with population projections sourced from the United Nations Population Database and Eurostat.

For the period beyond 2014, the projections incorporate the same macroeconomic policy assumptions as in Johansson et al. (2013): 
- Inflation is determined from a Phillips curve that includes the output gap and commodity prices. Real oil prices are assumed to rise by about 5\% per annum from 2014 to 2020, 2\% per annum from 2020 to 2030 and $1 \%$ per annum thereafter.

- Bilateral exchange rates between most OECD countries remain unchanged in real terms. The real dollar exchange rates for non-OECD countries, and OECD countries below a certain real per capita income threshold, appreciate in line with convergence in living standards, through the so-called Harrod-Balassa-Samuelson effect.

- $\quad$ Policy interest rates continue to normalise as output gaps close and beyond that converge to a neutral real short-term rate, which equals the potential growth rate of the economy. The inflation target is $2 \%$ for most countries including New Zealand.

- $\quad$ Actions are taken to stabilise the public debt-to-GDP ratio, with a gradual increase in the underlying fiscal primary balance of $1 / 2$ percentage point of GDP per year from 2014 onwards through a combination of reduced government spending and higher revenues until the ratio of government debt to GDP is stable, given long-term trend growth and long-term interest rates. The impact of consolidation on demand is assumed to be partly offset by favourable Ricardian effects.

- There is no further harm to government balance sheets as a result of asset purchases or guarantees made in dealing with the financial crisis. No contribution to deficit or (gross) debt reduction is assumed from government asset sales.

- Effects on public budgets from population ageing and continued upward pressures on health spending are not explicitly included, or, put differently, they are implicitly assumed to be alleviated through reforms of relevant spending programmes or offset by other budgetary measures.

Assumptions on structural policies are the same as those in Johansson et al. (2013), except those regarding the pensionable age and educational attainment for New Zealand:

- There is no change to the legal pensionable age for New Zealand. Labour force entry and exit rates for each age cohort are assumed to remain constant, and changes in the aggregate labour force participation rate reflect solely the effects of demographic ageing.

- There are no labour-market hysteresis effects: structural unemployment gradually returns to the lowest value estimated between 2007 and 2013; for New Zealand this is $4.3 \%$.

- There is no change to NZ educational policy, and the stock of human capital evolves with the ageing population: average years of schooling per worker (the proxy that represents human capital) increases as the more highly educated younger cohorts age and less educated older workers retire. Successive generations are assumed to have the same attainment as the current cohort with the highest years of schooling.

- $\quad$ Product market regulations remain unchanged in New Zealand (and converge towards the OECD average for countries whose stances are more restrictive than average).

- Trade intensity, as defined by the sum of exports and imports as a share of GDP, remains constant.

In this baseline, it is assumed that no policy changes are implemented in New Zealand to raise the pension age or rates of human capital accumulation. This differs somewhat from the assumptions made in the benign scenario presented in Johansson et al. (2013), which assumes all countries enact reforms to boost effective retirement ages and converge towards educational attainment levels of the world frontier. Under those assumptions, through the conditional convergence process, New Zealand's income gap vis-à-vis the United States narrows to about $27 \%$ by 2060 (from 42\% in 2011), and more modestly with respect to Australia to $23 \%$ (from $30 \%$ in 2011). In either case, the projection assumes that MFP contributes much more to growth in the future than has ever been observed in the past.

Relative to Australia, New Zealand's slower labour productivity growth since 1990 appears to reflect both lower average growth in MFP and (to a lesser extent) in capital accumulation. Analysis that takes into 
account industrial structure reveals that structural differences between Australia and New Zealand account for less than one third of the labour productivity level gap, whereas performance at the sector level matters most (NZIER, 2011). However, New Zealand's lower overall capital intensity appears to be $90 \%$ explained by differences in industrial structure. None of the economy's major sectors have experienced substantial MFP gains since the 2000s.

The reasons for New Zealand's productivity underperformance despite its strong institutions (the "productivity paradox") are not well understood. Indeed, New Zealand is an outlier in the extent to which actual labour productivity growth has undershot predicted rates based on policy settings (Barnes et al., 2011). Given its high employment growth, lower productivity growth corresponds with evidence found by de Michelis et al. (2013) that cross-country increases in labour input cause reductions in MFP growth. Even so, New Zealand's MFP growth has still been lower than expected based on this estimated relationship. Part of its disappointing performance may reflect the persistence of comparatively high real interest rates since the 1990s, which may have helped depress business investment, and which appears to reflect low domestic savings relative to the investment needs of a rapidly growing population. Furthermore, the real exchange rate has failed to adjust downward with the country's relative decline in productivity vis-à-vis other advanced economies since the 1980s (Reddell, 2013). This exchange rate overvaluation may have constrained growth in the tradables sector.

It is widely recognised that New Zealand's size and geographic isolation have constrained its economic performance, perhaps reducing per capita GDP by up to $10 \%$ (Boulhol and de Serres, 2008). Good policies can nonetheless help counter New Zealand's geographic obstacles, and indeed the long-run deterioration in relative per capita incomes came to an end following the significant structural reforms of the 1980s and early 1990s (McCann, 2009). Strong institutional settings may explain the finding that both Australia and New Zealand perform better than predicted, given their distance to markets (Dolman et al., 2007). Nevertheless, bad geography argues for the need to have particularly strong structural policies, especially as isolation may reduce the returns to structural and institutional reform (Gallup and Sachs, 1999). In particular, reforms that lower the cost of transportation and communications and diminish barriers to trade should help shorten New Zealand's effective economic distance from trading partners and favour greater integration with the global economy.

\section{Taking advantage of globalisation}

A dynamic tradables sector may provide longer-term benefits to overall productivity and growth through various channels, including the diffusion of foreign technologies and knowledge (New Zealand Treasury, 2010). Trade intensity is low in New Zealand compared to other OECD countries of similar size (Figure 3) and has remained roughly unchanged since the 1980s, despite increasing globalisation. This may be attributable in large part to the country's isolation, given analyses based on "gravity models" that suggest trade intensity is not far from what would be predicted given its remoteness (Battersby and Ewing, 2005; OECD, 2013c). While the country ranked 21st out of 60 nations in a recent Ernst and Young index of global connectedness, this was down two places from its 1995 standing (Ernst and Young, 2012). Furthermore, recent OECD work using the OECD-WTO Trade in Value Added (TiVA) database suggests that New Zealand's overall participation in global value chains (GVCs) is low by international standards (Figure 4). This finding suggests that it may have benefited less than others from many of globalisation's productivity-enhancing effects. However, this work also reveals that New Zealand's connection to GVCs is among the highest within the agriculture and food sectors (Miroudot and de Backer, 2012). 
Figure 3. Trade intensity ${ }^{1}$

2012 or latest available year

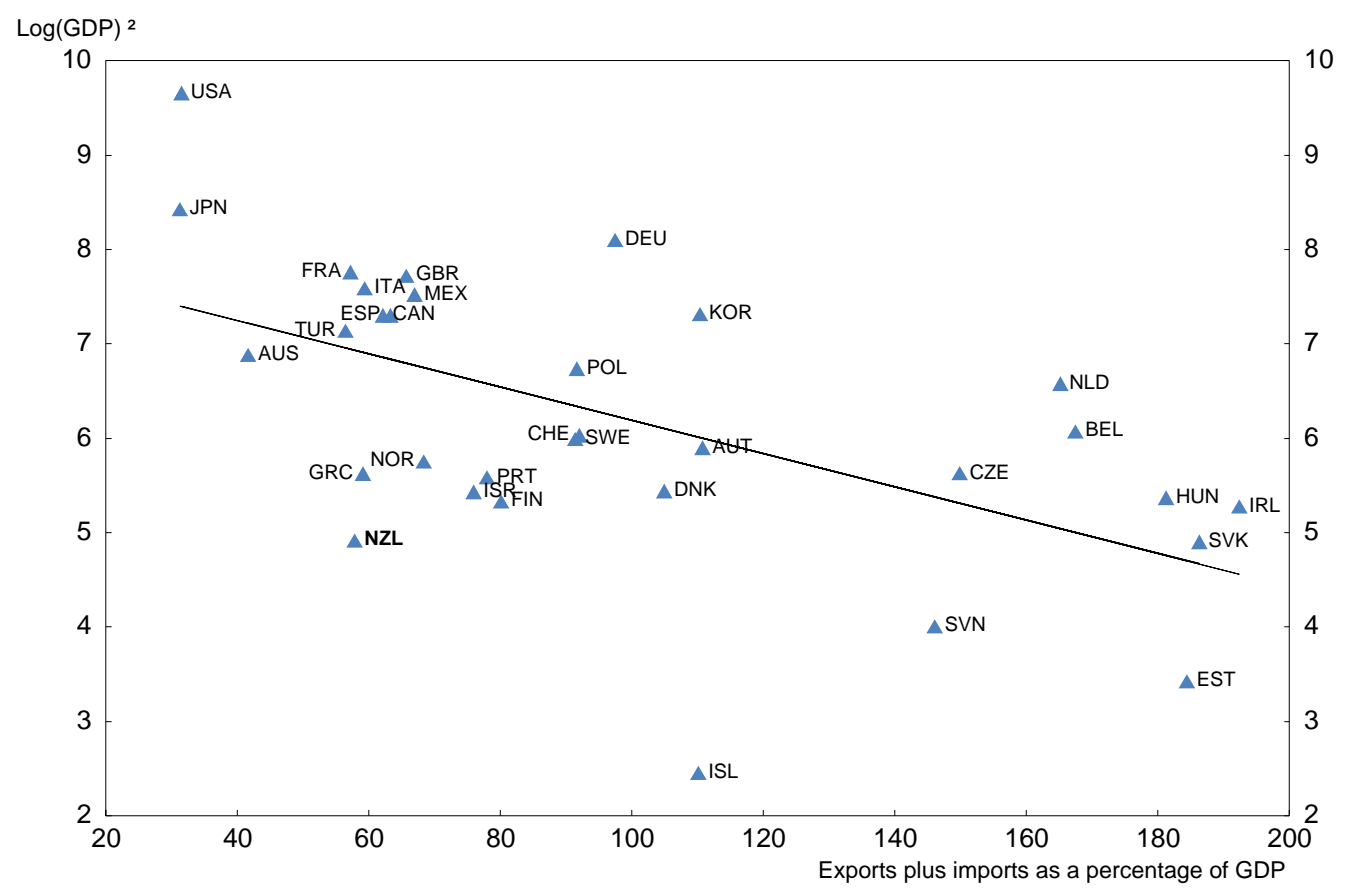

1. Intensity is defined as the sum of nominal exports and imports of goods and services divided by GDP.

2. USD billion, current prices, current PPPs.

Source: OECD Economic Outlook 92 database.

Figure 4. Global value chain participation index in OECD countries 2008

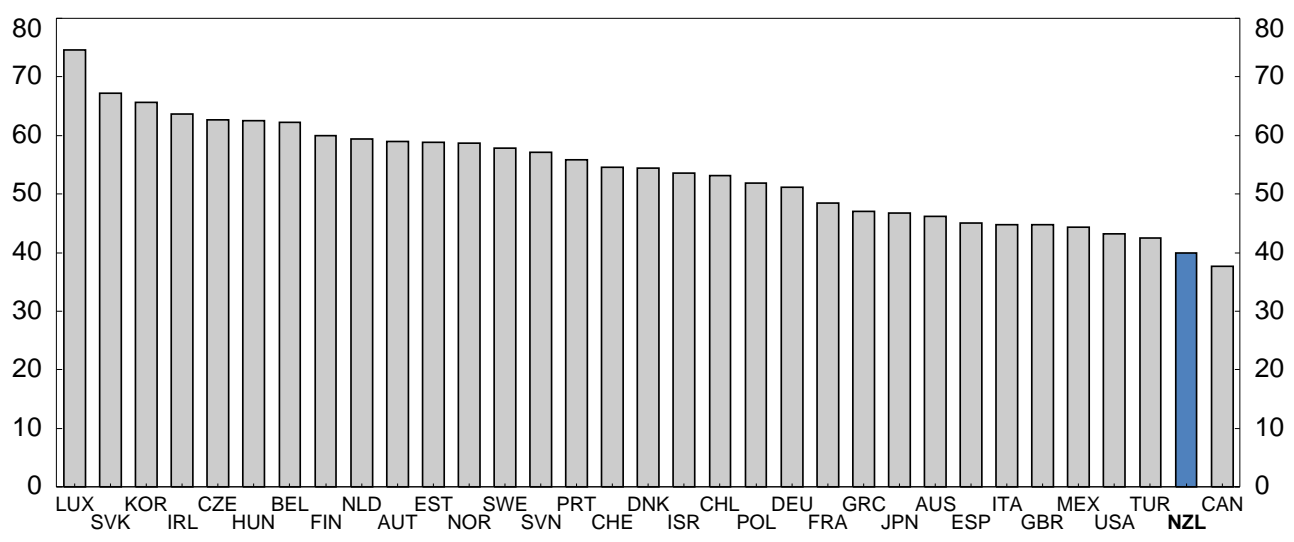

Source: OECD (2012), Policy Dialogue on Aid for Trade, Mapping Global Value Chains.

How to read this figure: The participation index is calculated as the sum of: i) the share of foreign inputs in overall exports, and ii) the share of gross exports that are used as inputs in other countries' exports.

While engaging in GVCs can be a powerful driver of growth, productivity and employment, a country's position in the chain also determines how much it will benefit. In particular, the highest value 
tends to be created in "upstream" activities, like R\&D and product design, or in the "downstream" segments of marketing and branding (OECD, 2013a). As will be discussed below, a highly skilled labour force and strong institutions should give New Zealand a comparative advantage in these types of activities. Increasing investment in knowledge-based capital can also help it upgrade its value added within GVCs (OECD, 2013a).

\section{The evolving importance of geography}

Remoteness and a small, scattered population limit the extent to which domestic firms can exploit scale economies while weakening competitive pressures to innovate and seek efficiencies. Because of the thin domestic market, NZ firms outgrow it sooner and must therefore internationalise at an earlier stage in the life cycle (New Zealand Treasury, 2009b). Many eventually relocate operations entirely overseas to be closer to large markets, resulting in a loss of high-skill jobs, tax revenues and other benefits. International knowledge diffusion may also be slower to distant countries (Comin et al., 2012).

These geographic disadvantages are probably compounded by other structural factors and policy settings that together limit New Zealand's international connections and the extent to which the economy has benefited from them. In particular, its export base remains heavily reliant on agriculture, which is highly productive but typically faces greater supply constraints and higher trade barriers worldwide; by one estimate, full global liberalisation of agriculture and food markets could increase NZ exports in these goods by $72 \%$ (Anderson, 2008). Outward direct investment is among the lowest in the OECD, with little use of offshoring in the manufacturing sector in particular (New Zealand Treasury, 2009b), which may again be due to high distance-related transportation costs. It may also reflect the fact that many high-growth firms that do offshore manufacturing processes eventually move all their operations overseas to exploit co-location synergies (Sweet and Nash, 2007). The relatively strict taxation regime on offshore investments that was in place until 2009 may have also played a role (OECD, 2007a). Finally, New Zealand's main export sectors tend to be dominated by firms with governance structures that may be less conducive to competition and innovation (state owned enterprises, cooperatives, privately held trusts).

Whether globalisation and technological advances have made geographic obstacles more or less important for New Zealand's economic performance is open to debate. On the one hand, studies suggest more generally that the importance of physical distance for trade has not diminished (Boulhol and de Serres, 2008) and may have even increased over time for both goods and services (Nordäs, 2008a), despite declining costs of transportation and communication. Globally, the average distance of trade has actually shortened over the past few decades, with more trade occurring between neighbours rather than with distant countries (Skilling and Boven, 2007). These patterns reflect the highly regional nature of GVCs as well as the increasing importance of speed to market, flexibility and timeliness of supply. This implies that proximity to markets and co-location with other suppliers may heavily influence firms' location choices. Global competition has reduced mark-ups and increased the substitutability of goods, which may make trade even more cost sensitive (Boulhol and de Serres, 2008). Such factors place firms operating in distant markets such as New Zealand at a competitive disadvantage in selling certain products.

On the other hand, the gravitational shift of global economic activity from west to east is improving the country's proximity to major markets. While these markets may be more distant in terms of linguistic and cultural differences, New Zealand may be better placed than many others to overcome these barriers, given its large Asian population and strong social ties to the region. By the mid-2000s, New Zealand was the ninth largest recipient of Asian immigrants in the OECD, and almost $40 \%$ of these immigrants had tertiary education (Table 2). Asians account for over $8 \%$ of all students at the tertiary level, with only Australia boasting a higher share (Figure 5). Studies have shown that immigrant networks significantly 
Table 2. Migrant stock of persons born in Asia living in OECD countries, 2005-06

\begin{tabular}{|c|c|c|c|c|}
\hline $\begin{array}{l}\text { Country of } \\
\text { residence }\end{array}$ & $\begin{array}{l}\text { Asian migrants } \\
\text { aged } 15 \text { and over }\end{array}$ & $\begin{array}{l}\text { Share of population } \\
\text { aged } 15 \text { and over }\end{array}$ & $\begin{array}{l}\text { Share among total } \\
\text { immigrant population }\end{array}$ & $\begin{array}{c}\text { Share of } \\
\text { tertiary-educated } \\
\text { among Asian migrants }\end{array}$ \\
\hline & Thousands & \multicolumn{3}{|c|}{ Percentages } \\
\hline United States & 7760 & 3.3 & 20 & 52 \\
\hline Canada & 2143 & 8.0 & 35 & 52 \\
\hline United Kingdom & 1557 & 3.2 & 29 & 39 \\
\hline Australia & 1155 & 7.0 & 28 & 42 \\
\hline Japan & 546 & 0.5 & 42 & 25 \\
\hline France & 436 & 0.9 & 7 & 30 \\
\hline Italy & 266 & 0.5 & 9 & 7 \\
\hline Netherlands & 264 & 2.0 & 18 & 25 \\
\hline New Zealand & 225 & 6.9 & 29 & 37 \\
\hline Germany & 222 & 0.3 & 2 & 19 \\
\hline Korea & 179 & 0.5 & 78 & 32 \\
\hline Spain & 119 & 0.3 & 3 & 18 \\
\hline Sweden & 99 & 1.3 & 9 & 25 \\
\hline Switzerland & 93 & 1.5 & 6 & 32 \\
\hline Denmark & 70 & 1.6 & 19 & 18 \\
\hline Norway & 68 & 1.8 & 21 & 16 \\
\hline Belgium & 63 & 0.7 & 5 & 31 \\
\hline Austria & 61 & 0.9 & 6 & 20 \\
\hline Ireland & 44 & 1.3 & 8 & 59 \\
\hline Czech Republic & 43 & 0.5 & 8 & 13 \\
\hline Israel & 34 & 0.7 & 2 & 31 \\
\hline Other & 71 & 0.0 & 5 & 13 \\
\hline Total & 15518 & 1.6 & 31 & 40 \\
\hline
\end{tabular}

Note: Information on data for Israel: http://dx.doi.org/10.1787/888932315602.

Source: Database on Immigrants in OECD Countries 2005/06.

Figure 5. International students from Asia in OECD countries

In tertiary education, as a percentage of all students, 2009

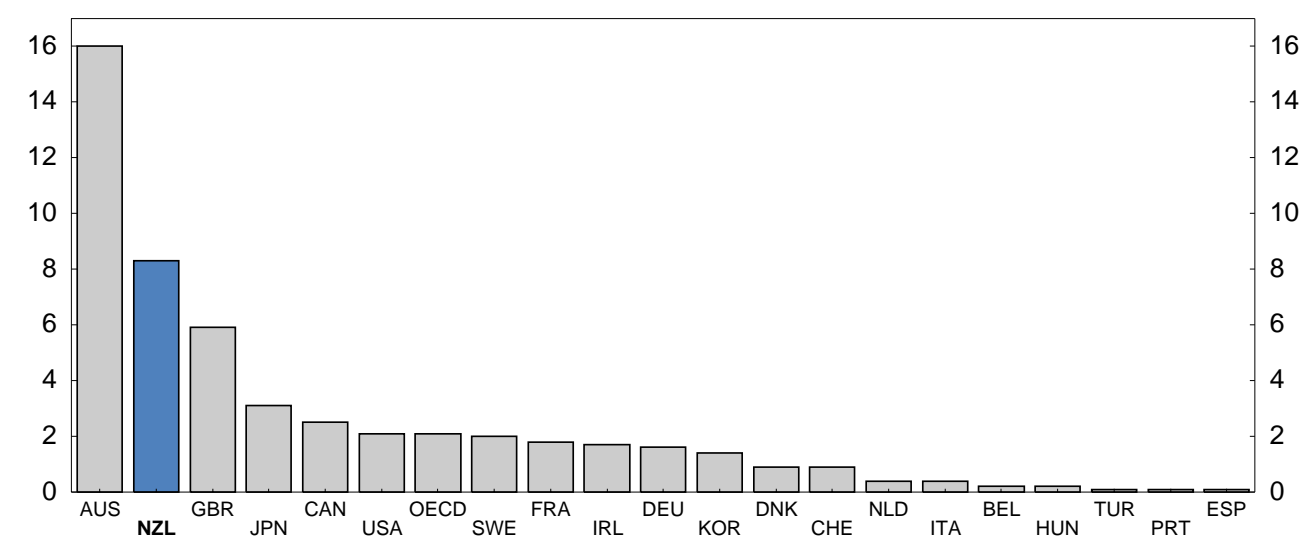

Source: OECD International Migration Outlook 2012.

increase trade in goods and services (Rauch and Trindade, 2002; Rauch, 1999), although for New Zealand they have tended to stimulate imports more than exports (Law et al., 2009). Furthermore, compared to the 
West, the smaller time zone difference between New Zealand and East Asian markets can benefit FDI and services trade, since many services require real-time communication (Kandilov and Grennes, 2012).

Firms can offset the disadvantages of isolation through greater offshoring of production and distribution processes to facilities closer to major international markets or hubs (Skilling and Boven, 2007). This levels the playing field with foreign rivals as far as production and distribution costs and speed to market and could shift the basis of competition towards higher value-added activities such as R\&D, branding and design. Indeed, New Zealand appears to perform reasonably well in trademark activity by OECD standards, signifying some potential strengths in branding and design (Figure 6).

\section{Figure 6. Triadic trademark applications at JPO, OHIM and USPTO, 2007-09 average}

\section{Trademarks relative to GDP}

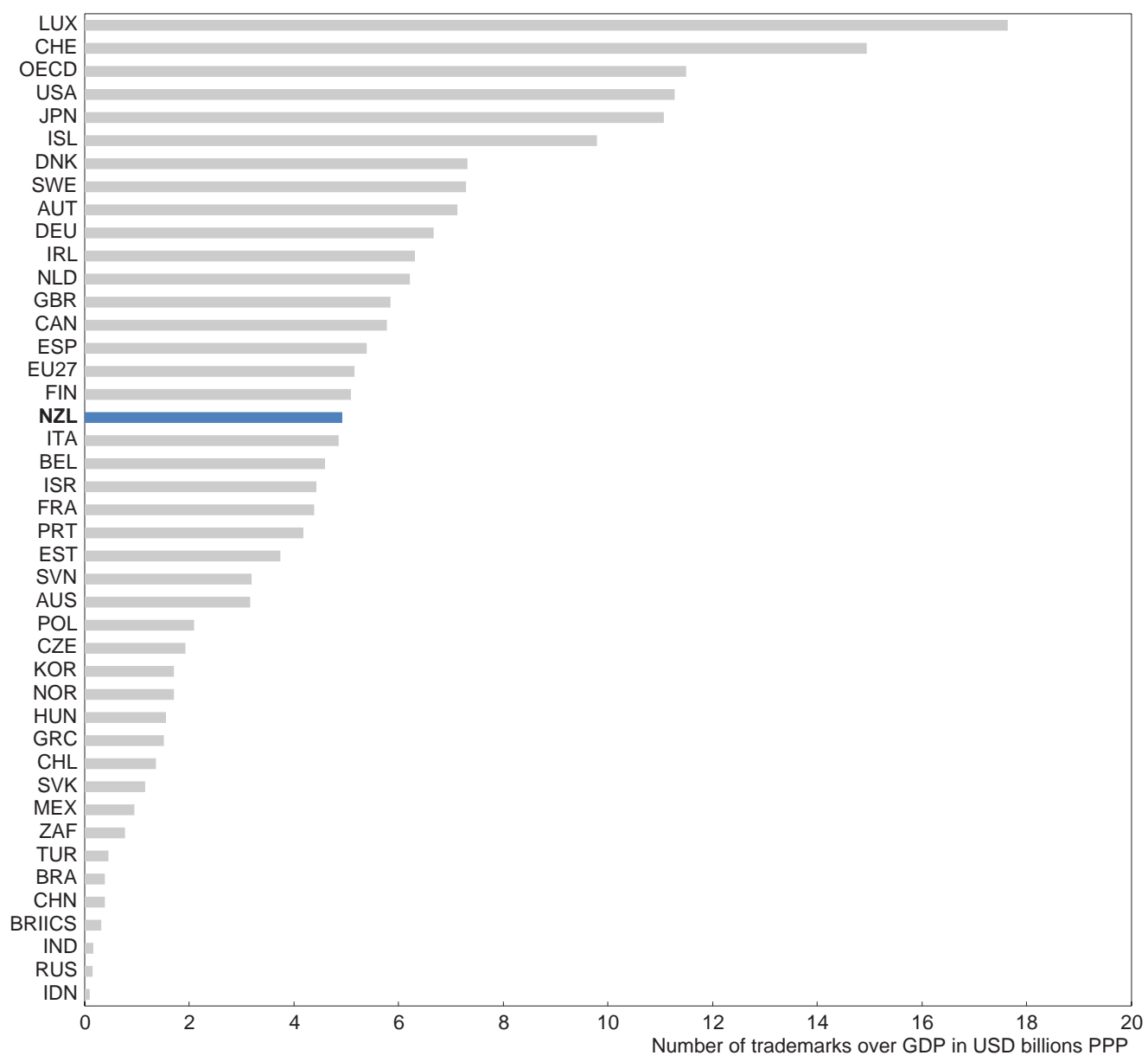

Source: OECD Science, Technology and Industry Scoreboard 2011.

\section{Factors shaping New Zealand's comparative advantage}

Changes in transportation costs significantly affect the importance of distance for trade by altering relative prices across exporters. From the 1950s until the mid-2000s, the real cost per kilogram of air cargo declined significantly relative to maritime shipping, contributing to a growing share of long- distance trade occurring via air rather than ocean (Hummels, 2009). Furthermore, there are indications that prices declined more for long-haul flights than for intra-continental flights during this period (WTO, 2008). 
Those gaining most from its cost reductions would have been faraway countries producing high-value, low-weight goods for which rapid delivery is critical. In particular, vertical supply chains in manufacturing rely heavily on air transport, consistent with findings that the most time-sensitive trade flows are in parts and components (Hummels and Schaur, 2012). The share of New Zealand's merchandise trade value that is transported by air has hovered around 20\% since 1989, compared to international norms of about 35-40\% (Skilling and Boven, 2007). The country's agriculture-based exports tend to be heavy, relatively low value per tonne and not time-sensitive, making transport by ship much more economical. Going forward, however, further increases in fuel prices may erode the relative gains from shipping by air rather than ocean. Indeed, US and EU data reveal that the real cost of air cargo has increased since the early 2000s, while air usage has dropped, probably reflecting higher energy costs and security regulations.

While distance appears to have become less important for trade in standardised, low value-added goods and services, it remains a barrier for activities that require human interaction, variety, customisation and local knowledge (McCann, 2009). New Zealand's population sparseness further places it at a disadvantage for realising agglomeration economies, which have become more important for many high value-added, knowledge-intensive activities. For example, firms in the information and communications technology (ICT) industry often prefer clustering together in either large cities or where deep specialised labour pools already exist. Such locations provide greater opportunities for chance encounters with potential investors, clients or partners, as well as for face-to-face brainstorming sessions that can be more productive than phone calls or e-mails. A survey of NZ export-oriented firms reveals that a lack of critical mass with specific technology skills is a major factor behind decisions to rebase activities in foreign countries, where larger labour markets make such skills more readily available (Sweet and Nash, 2007).

In services, the importance of distance for tradability varies significantly by the type of service. A study by Nordäs (2008b) presents empirical analysis suggesting that distance is a significant factor determining whether any two given countries will engage in business services trade. That study also finds that the disadvantage of remoteness is larger for smaller countries. It reasons that trade costs for commercial services depend on the transaction costs of searching for a suitable supplier and of drawing up and monitoring contracts. Because the quality of service outputs is more difficult to measure and assess than that of manufactured goods, there may be a stronger home bias in establishing business service contracts.

Because of these various transaction costs, Nordäs (2008a) argues that the most tradable commercial services are those that can be codified and transmitted electronically, that have high information content and that require no face-to-face contact. As with manufactured goods, the more generic the product, the easier it is to verify and enforce a contract and therefore engage in trade. By contrast, less easily tradable (but nonetheless tradable) services are those emphasising customisation, local knowledge, trust and face-to-face interaction, such as consultancy, design and R\&D. These types of services are generally higher value, and delivery may require a commercial presence in the foreign country and physical movement of people. Because these non-standardised services involve greater risks with contract enforcement, countries with strong institutions like New Zealand have a comparative advantage in producing them (WTO, 2008), and this could translate into either higher exports or outward foreign direct investment (FDI).

It has been argued that continued preferences for timely delivery and improvements in communications technology are likely to shift the comparative advantage of remote countries like New Zealand towards exporting lightweight high-value goods and services that are relatively insensitive to distance (Harrigan, 2010; Skilling and Boven, 2007). The value per tonne of NZ exports has actually increased very little over time, however: by only about 10\% between 1989 and 2012. Meanwhile, others have predicted that the growing importance of China and India in the world economy will tend to strengthen New Zealand's comparative advantage in agriculture, forestry products and coal (Dimaranan et al., 2007). 


\section{Reforms to increase international connectedness and value added}

Improving New Zealand's international linkages via trade, FDI and various forms of human interaction is crucial for mitigating the penalty of distance on growth and expanding the possibilities for knowledge transfer. Adopting ideas and technology from abroad is particularly vital for driving innovation in a small open economy that is not at the technological forefront. The government is seeking ways to boost trade intensity and has set an ambitious goal within its Business Growth Agenda to increase the share of exports to $40 \%$ of GDP by 2025 from current levels of about 30\%. Not only is a high-performance transportation and ICT infrastructure critical, but New Zealand needs to lower spatial transactions costs by even more than other countries to reduce its effective distance from markets (Boulhol and de Serres, 2008).

Transferring resources towards high-value added activities that leverage off New Zealand's strong primary-industry base may hold the most promise for strengthening productivity and competitiveness. Focus will need to be shifted towards activities that rely more on knowledge, technology and intangible assets. New Zealand has already made some noteworthy advances in this direction, notably in biotechnology, and is beginning to devote resources to developing a high-value manufacturing and services sector.

Simulations using the OECD long-term growth model suggest that boosting trade intensity steadily from 2015 to achieve the Business Growth Agenda target of a 40\% share of exports in GDP (and the same share for imports) by 2025 would raise annual real output growth by up to 0.1 percentage point (Figure 7 , Panel A). The positive impact occurs through a more rapid catch-up of MFP towards its steady state level, based on faster diffusion of technology and knowledge from abroad. Assuming trade intensity remains constant thereafter, the effect on growth would then slowly diminish, with real GDP levels $3 \%$ higher in the long run (Panel B). However, this estimate probably understates the true impact since it does not take into account the productivity gains that may arise from greater competition as trade intensity increases. Furthermore, if higher trade intensity results from reforms that lower trade barriers or improve ICT infrastructure, the steady state level of MFP could also increase.

Figure 7. Simulated real GDP impact of increasing trade intensity

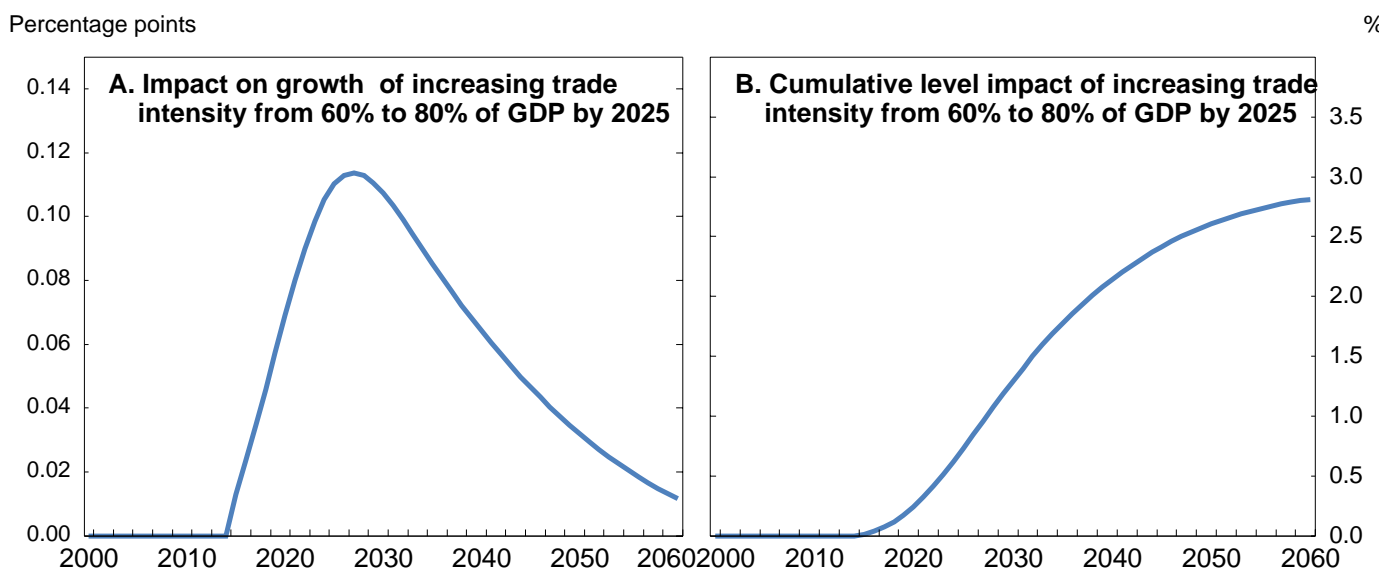

Source: OECD calculations.

Facilitate services trade through high-performance ICT infrastructure

There are several reasons why expanding the role of services trade has significant potential to drive New Zealand's future growth. These include, first, the declining costs of ICT and increasing Internet 
adoption worldwide, which allow smaller firms to enter foreign markets at lower cost. Second, services make up over $70 \%$ of New Zealand's GDP, but only about one quarter of its exports based on national accounts gross measures. However, OECD-WTO TiVA data suggest that services value added in exports is almost twice as important, accounting for $46 \%$ of total exports in 2009 (Figure 8). Third, in contrast to its traditional agricultural export base, services face fewer natural-resource constraints such as land availability and environmental objectives. Finally, tradable business services employ high and medium skilled workers more intensively, who tend to earn higher wages than those in manufacturing or non-tradable services (Gonzales et al., 2012).

Figure 8. Services value added as a share of gross exports

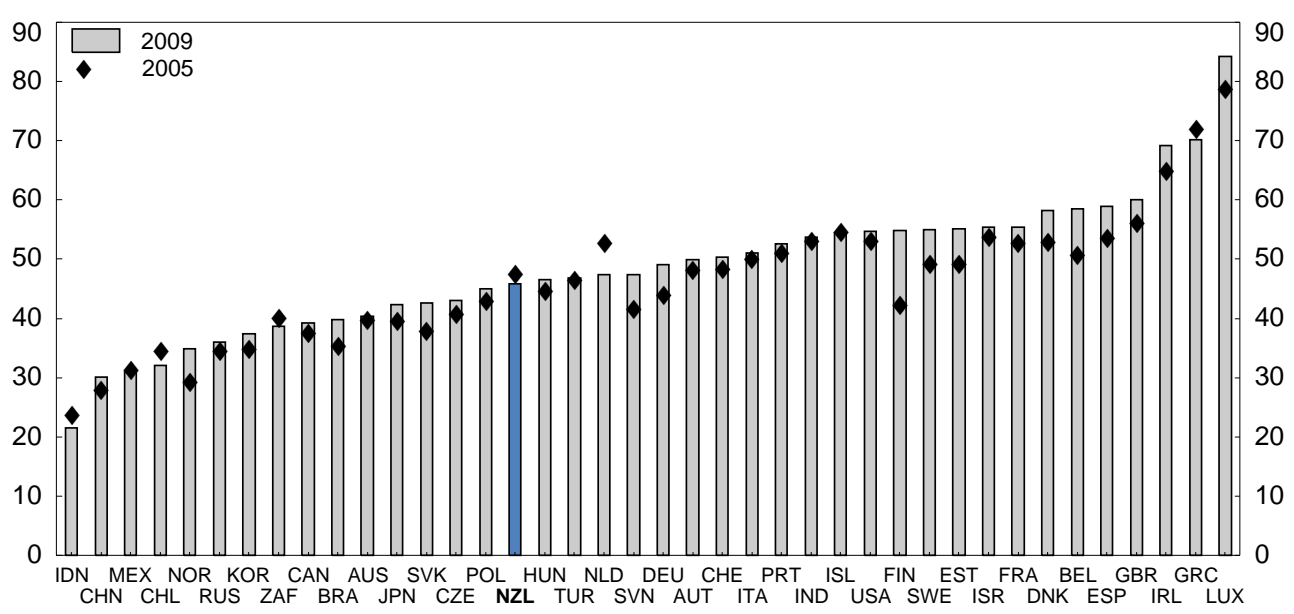

Source: OECD, OECD-WTO Trade in Value Added database.

In New Zealand gross services trade has shrunk as a share of both total trade and GDP over the last decade, declining to about $24 \%$ of total trade in 2012 compared to $27 \%$ in the early 2000 s. The majority of both services imports and exports is in tourism and transportation services. Travel accounts for the largest share at over one half of total services exports, which is based on the physical movement of people and therefore highly dependent on air transport. "Weightless" services exports (e.g. communication services, financial and insurance services, computer and information services) account for only about $20 \%$ of total services exports, compared to $50 \%$ on average for OECD countries. New Zealand has generally been a net importer of business services, but its exports in this area have increased at twice the pace of imports since 2000. Financial and computer and information services have experienced among the highest growth in exports over this period. Furthermore, even if NZ exporters of computer services are not heavy participants in GVCs, they tend to be located favourably at the upstream end, based on measures of "distance" to final demand (Figure 9), indicating a specialisation in high value R\&D and design.

Numerous barriers to services trade can arise, including natural barriers such as language and culture, as well as those arising from differences in technology, labour mobility and domestic regulation (New Zealand Treasury, 2009b). Direct trade barriers can include restrictions on foreign ownership and other market access, while implicit barriers can take the form of behind-the-border regulation, such as licensing procedures (Nordäs, 2008a). Based on the World Bank's Services Trade Restrictiveness Index, the services sector overall ranks as one of the most open to trade among OECD countries and also quite favourably across most sub-sectors (Figure 10, Panel A). The main exception is in telecommunications (Panel B), which reflects in large part a limit of $49.9 \%$ on foreign ownership of Chorus, the major telecommunications infrastructure provider. Few other OECD countries have retained foreign investment restrictions in telecommunications. As argued in the 2011 Economic Survey (OECD, 2011c), such restrictions and the Telecommunications Service Obligations (TSO) (e.g. to provide free local calling) 
distort competition, create inefficiencies and should be eliminated. Indeed, New Zealand users face comparatively high prices for fixed line and mobile communications across most residential and business consumption baskets (OECD, 2013b), though this may also reflect a lack of retail competition. These issues should be considered within the telecommunications regulatory review currently underway.

Figure 9. Participation and position in computer services global value chains

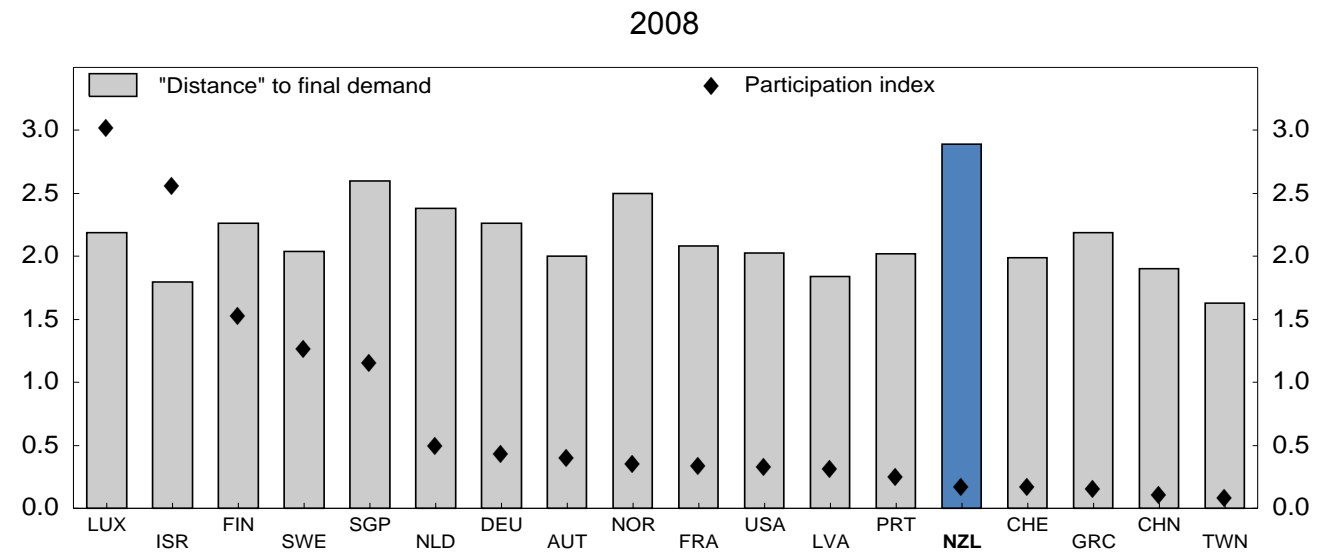

Source: OECD (2012), Policy Dialogue on Aid for Trade, Mapping Global Value Chains.

How to read this figure: The participation index is calculated as the sum of: $i$ ) the share of foreign inputs in overall exports, and ii) the share of gross exports that are used as inputs in other countries' exports. The distance to final demand is a measure of "upstreamness" in a global value chain. Longer distances indicate a specialisation in producing inputs closer to the beginning of the value chain, which includes higher value activities such as R\&D and product design.

\section{Figure 10. Services Trade Restrictiveness Index}

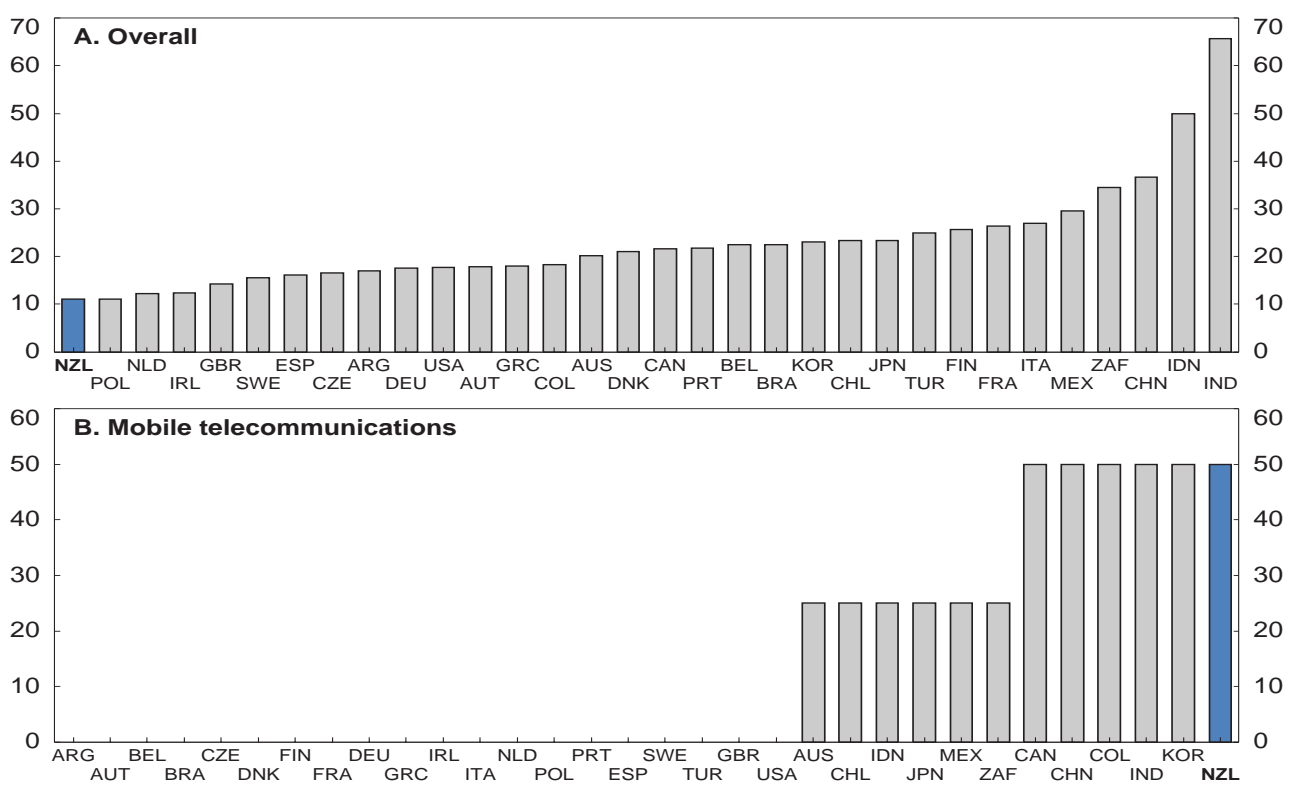

Source: World Bank.

How to read this figure: This index summarises the restrictiveness of applied policies on services trade, on a scale of 0 (completely open) to 100 (completely closed). Scores are assigned for various service sectors, and to construct the aggregate index each sector is weighted by its share in the country's value added. 
A high-performance ICT infrastructure is essential to overcoming the country's geographic disadvantages and expanding services trade. As a share of GDP, ICT expenditures in New Zealand are well below the OECD average (New Zealand Government, 2011). Broadband internet penetration is nonetheless comparatively high, with over two-thirds of inhabitants connected through a wireless subscription and over one quarter through a fixed wire at end-2011. Almost 95\% of businesses report broadband access. Internet access remains relatively slow (Figure 11) and expensive, however, with broadband entry prices among the highest in the OECD (Figure 12), although prices have come down by over $20 \%$ since 2008 . New Zealand is one of the few countries to impose data caps on all broadband packages offered. Relatively high prices may reflect in part the cost of providing widespread network coverage across a sparsely populated country.

The government is currently investing significantly in laying ultra-fast broadband (UFB) with the goal of bringing higher speed Internet access to $75 \%$ of the population by 2020 . The scheme involves construction of a fibre network via a number of public-private partnerships, involving NZD 1.5 billion in direct subsidies. There appears to be widespread industry acceptance globally that optical fibre will become the predominant technology of the future (Stanislawski and Krauze, 2013), given its greater speed and lower lifetime cost relative to copper. While regulated prices charged for broadband normally incorporate the future cost of replacing the infrastructure, the monopolistic nature of the industry has resulted in little private investment in fibre thus far. As a result, governments have tended to play a major role in the migration towards fibre, with those of Japan, Korea and Australia being most notable. While greater and faster internal Internet connectivity should foster productivity gains, the strength of New Zealand's links to the rest of the world will remain dependent on the single Southern Cross cable joining Auckland to Sydney. Capacity has been added incrementally over time and currently appears sufficient for domestic needs. It is presumed that broadening high-speed Internet usage internally first will help stimulate demand and competitive pressures to ultimately invest in a second cable.

Figure 11. Average measured connection speeds by country

Average Mbit/s, 2012Q3

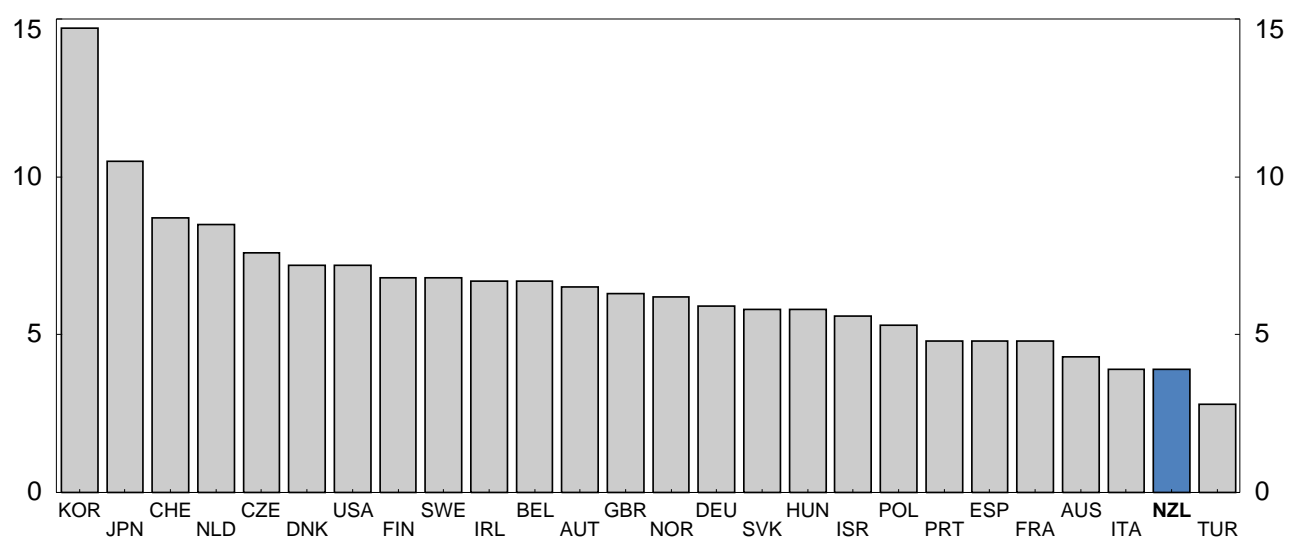

Source: Akamai State of the Internet Report, 2012Q3. 
Figure 12. Range of broadband prices for a monthly subscription - including line charge

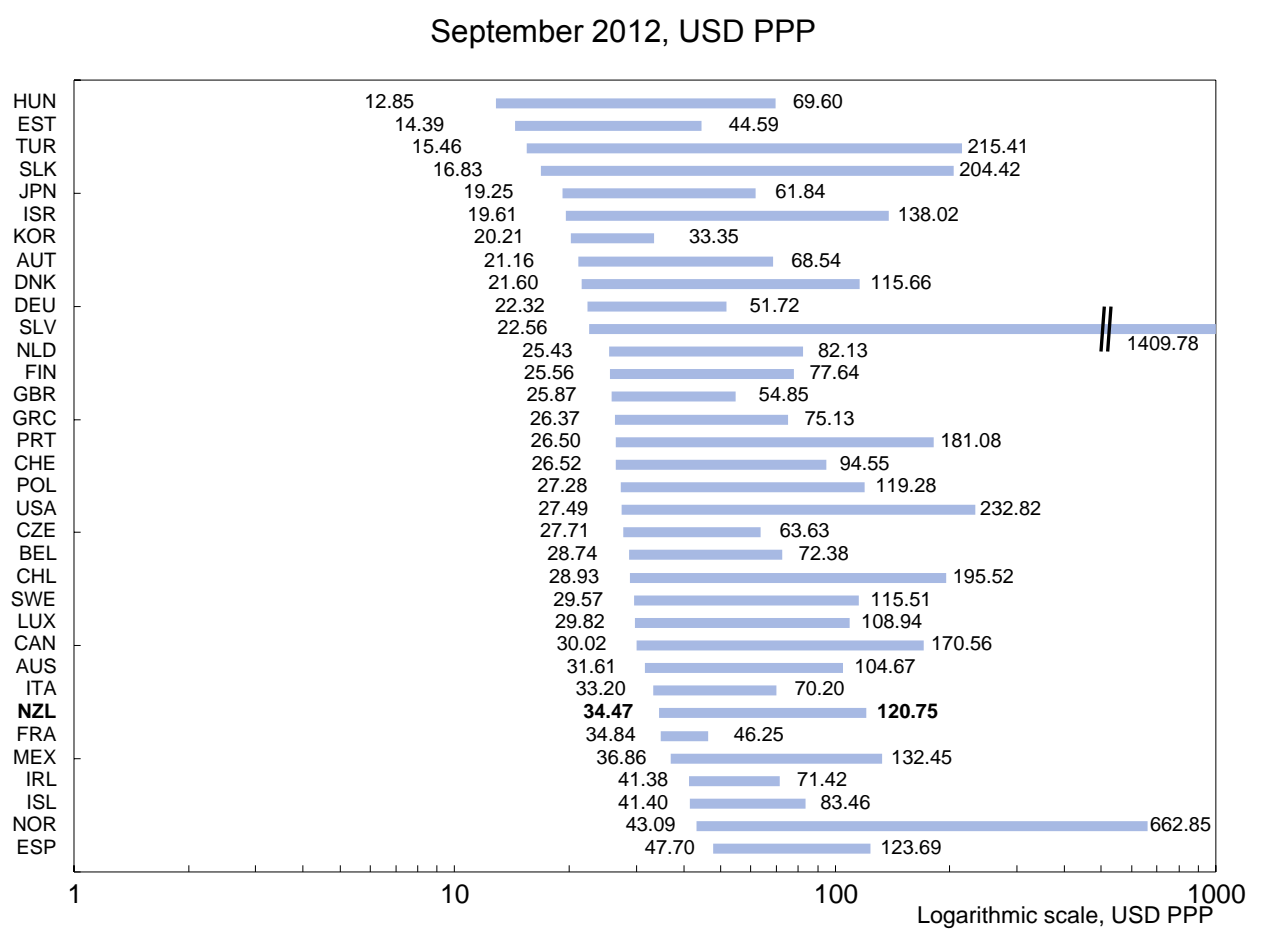

Source: OECD (2013), OECD Communication Outlook 2013 (forthcoming).

The UFB initiative introduces considerable regulatory uncertainty into the sector's competition framework. As the fibre network is being deployed, the government continues to require competitive wholesale pricing on the existing copper network. Reforms implemented over recent years to enhance competition and limit market power in the copper network include local loop unbundling in 2006, followed by the structural separation of Telecom NZ into two independent companies in 2011: Chorus (for the fixed access broadband network and wholesale operations) and Telecom (for mobile networks and retail functions). At the same time, a switch to forward-looking cost-based pricing required the Commerce Commission to set wholesale prices for access to the copper infrastructure (UBA) by benchmarking against corresponding prices charged in comparable countries that use a forward-looking cost-based approach. The Commerce Commission's 2012 review, which is subject to consultation, proposed steep cuts to the prices that Chorus can charge for its UBA service. The government has resisted these recommendations by postponing any change in UFB prices by one year, while in the meantime launching a comprehensive review of the entire telecommunications regulatory framework. Because Chorus is one of the major partners contracting with the government to deliver UFB (and therefore owns both fibre and copper infrastructure), the government is concerned that: $i$ ) such price discounts would substantially reduce Chorus' income and capacity to invest in UFB, and ii) cheaper access to the copper network could undermine the uptake of fibre.

Part of the problem is lack of clarity over how the fibre rollout will affect the copper network's future. This contrasts with the Australian approach, which involves decommissioning copper as fibre is laid (Howell, 2012): although this may facilitate longer-term investment planning and accelerate broadband uptake because of its transparency, it penalises those who own and use the copper network. To improve regulatory predictability for investors and consumers, the government should adjust its competition policy framework for the broadband market to ensure consistent regulation and pricing practices between copper 
and fibre networks. For example, wholesale prices for fibre access could be set using the same forward-looking cost-based methodology used for copper.

\section{Reduce regulatory restrictions in international trade, investment and transport services}

Given the importance of transportation costs in determining trade flows, having an efficient transport system is necessary to minimise costs and overcome geographic barriers. Infrastructure quality and market power for shipping lines are primary drivers of differing shipping costs across countries (Hummels, 2009). In 2012 the Productivity Commission completed a comprehensive examination of the efficiency of New Zealand's international freight transport system and concluded that the sector is quite effective overall in facilitating trade, though certain areas could use improvement (New Zealand Productivity Commission, 2012). The inquiry found that NZ ports and airports generally perform well compared to Australia's, but with substantial variation across different ports. The country's physical remoteness means its ports are not on major shipping lanes, and speed to market remains slow (Skilling and Boven, 2007). Furthermore, the consolidation of the shipping industry and the trend towards larger container ships imply that ships may visit NZ ports less frequently in the future. Many of the country's 12 major ports are small and have low financial returns due to over-investment in capital equipment (Skilling and Boven, 2007), suggesting there may be efficiency gains from some consolidation. As recommended in the 2009 Economic Survey, privatisation of port assets may help improve efficiency.

The Productivity Commission inquiry also identified regulatory impediments to competition in the shipping industry. In particular, international agreements between carriers are exempt from domestic competition law, including provisions that allow them to fix prices and limit capacity, based on the view that liner collaboration is necessary to ensure reliable services. However, international experience has provided little evidence that rate-fixing practices deliver net benefits, and many governments (including all EU countries) have removed the exemption of such agreements from competition law. Indeed, these exemptions may encourage inefficient anti-competitive behaviour that may raise costs unnecessarily. The government plans to pass a Commerce (Cartels and Other Matters) Amendment Bill that addresses this issue. This Bill will criminalise cartel conduct while permitting "collaborative activities" that create a net benefit without affecting prices. It would subject all ratemaking agreements to evaluation by the Commerce Commission on a case-by-case basis.

Regulation in the air transport sector may also need revisiting. Most air cargo is transported to the rest of the world on passenger aircraft, whose traffic routes depend on internationally negotiated air service agreements (ASAs). Although the impact of regulatory constraints on freight volumes is not clear, passenger capacity limits under ASAs with China, Hong Kong, India, Indonesia and France appear to have been reached and may be restraining both tourism and air cargo flows (New Zealand Productivity Commission, 2012). These ASAs should thus be urgently reviewed to ensure capacity limits are not hindering trade.

Formal trade barriers are low in New Zealand, with $95 \%$ of goods imported tariff-free (New Zealand Treasury, 2009b). With the most recent reduction implemented in 2009, tariffs remain on some domestically sensitive sectors, and the average weighted tariff rate is around $2.2 \%$. Border services are relatively efficient, and the government is developing a Trade Single Window to streamline export and import documentation requirements through a single electronic submission.

FDI can be a material source of productivity-enhancing knowledge spillovers. New Zealand has a relatively large stock of inward FDI (about 50\% of GDP), reflecting in part its low domestic saving and capital intensity, and dependence on foreign capital. Despite international evidence that FDI brings increased productivity and capital deepening, analysis of firm-level data finds no signs that high levels of FDI in New Zealand have had such effects (Fabling and Sanderson, 2011). Inward FDI has typically been 
concentrated in the banking industry, which accounts for almost $40 \%$ of total inflows, rather than in tradable sectors. A government evaluation of public programmes to facilitate FDI inflows reports that knowledge spillovers from FDI to the wider economy have been disappointingly small. This may be due in part to inadequate capacity to absorb foreign knowledge and technologies, which may be related to factors such as underdeveloped financial markets, a lack of human capital in areas such as engineering and management capabilities, low R\&D intensity and poor international connectedness (MED, 2011). These factors may constrain the country's ability to attract the type of "high-quality" FDI that enhances innovation and generates beneficial spillovers to productivity.

OECD model simulations suggest that moving New Zealand's product market regulations (PMRs) towards best-practice levels of restrictiveness could increase annual GDP growth by $0.2-0.3$ percentage point, with a long-term level gain of $12 \%$ (Figure 13). These estimates may be optimistic, however, given New Zealand's historical productivity underperformance relative to what would be predicted by its PMR settings (Barnes et al., 2011). By 2060, the gap between New Zealand's PMRs and the best-practice country narrows by $78 \%$. Reforms that could boost growth include increasing the transparency of the FDI screening regime. Screening restrictions exist for foreign investment involving significant business assets, sensitive land or fishing quota. The majority of foreign investment applications involve sensitive land, of which about 3.5\% were declined in 2002-08, whereas few business-type applications have been rejected since 1984. While these statistics indicate a reasonably liberal regime in practice, about $33 \%$ of the applications over this latter period were not decided upon for various reasons. Moreover, the screening regime may create uncertainties and dissuade applications from overseas investors due to the discretion used in weighting the criteria, as argued in the 2011 Economic Survey.

Figure 13. Projected real GDP impact of moving product market regulations to best practice

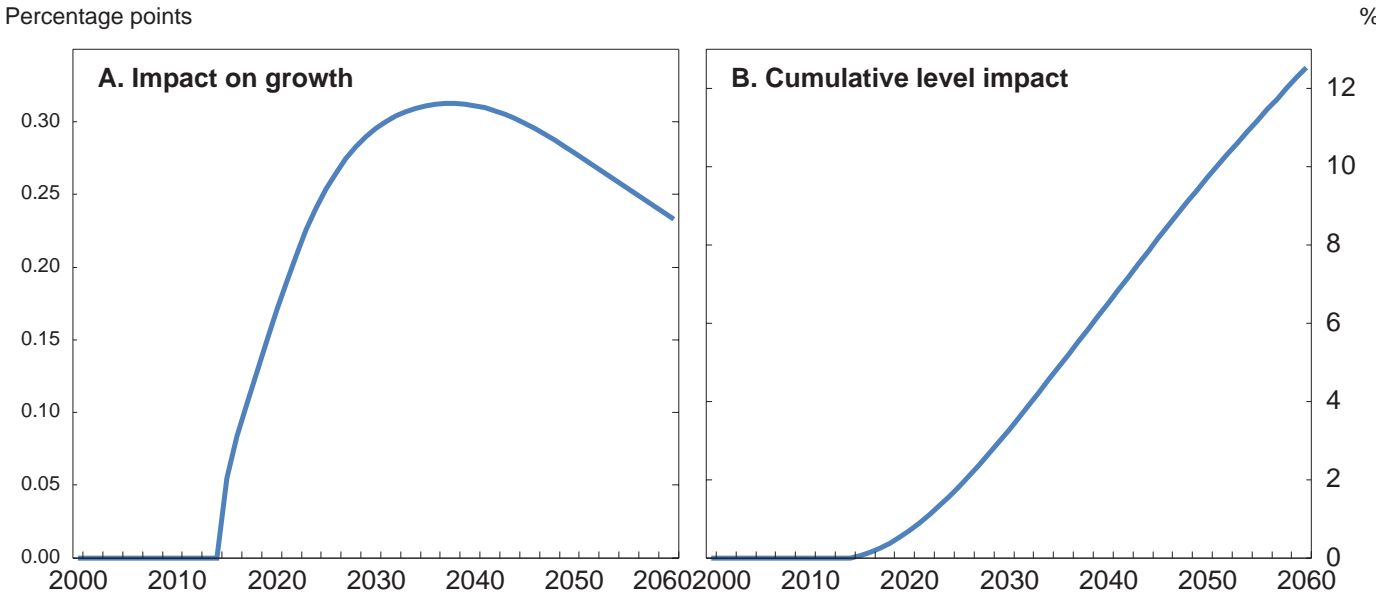

Source: OECD calculations.

\section{Adjusting policy settings to boost innovation}

Fostering innovation is key to raising productivity and living standards. Given New Zealand's geographical challenges, it is particularly crucial to stimulate innovation in export-oriented sectors as well as outward FDI through knowledge-based capital. The OECD published a review of New Zealand's innovation system in 2007 (OECD, 2007b) and identified various strengths and shortcomings in its performance and structural settings, many of which remain in place today. The country appears to boast a relatively strong base for scientific innovation: it ranks highly among OECD countries for scientific articles published in top journals, PISA math and science scores among 15 year-olds, science graduates per million population, and number of researchers engaged in R\&D (OECD, 2012a; OECD, 2011b). However, the supply of engineering graduates is low, and management capabilities appear weak (Figure 14): 
NZ firms are often seen as lacking in business acumen by their overseas counterparts (Procter, 2011). Business and government expenditures on R\&D are relatively low (Figure 15): as a share of GDP, total $\mathrm{R} \& \mathrm{D}$ is half the OECD average, and business R\&D just a third.

\section{Figure 14. Management scores in manufacturing ${ }^{1}$}

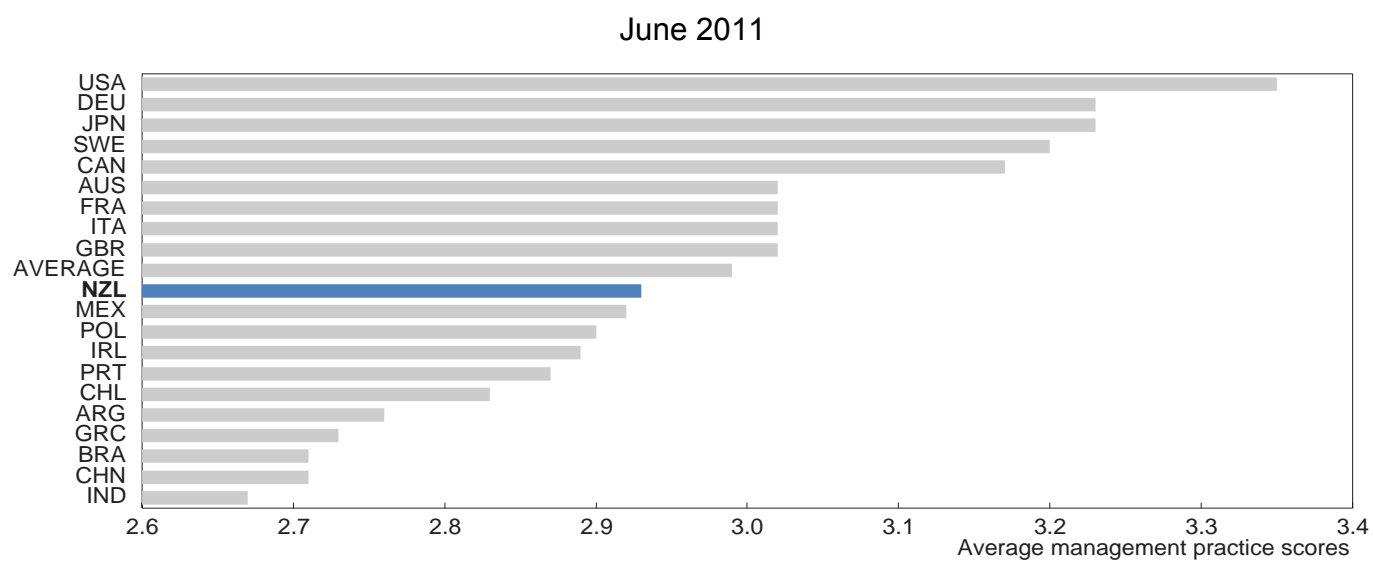

1. The overall management score is the average across all 18 questions. All questions are scored the same across all countries and industries.

Source: Bloom, N. et al. (2011), "Management practices across firms and countries", Harvard Business School Working Paper, No. 12-052, December.

Figure 15. Financial support for private R\&D investment

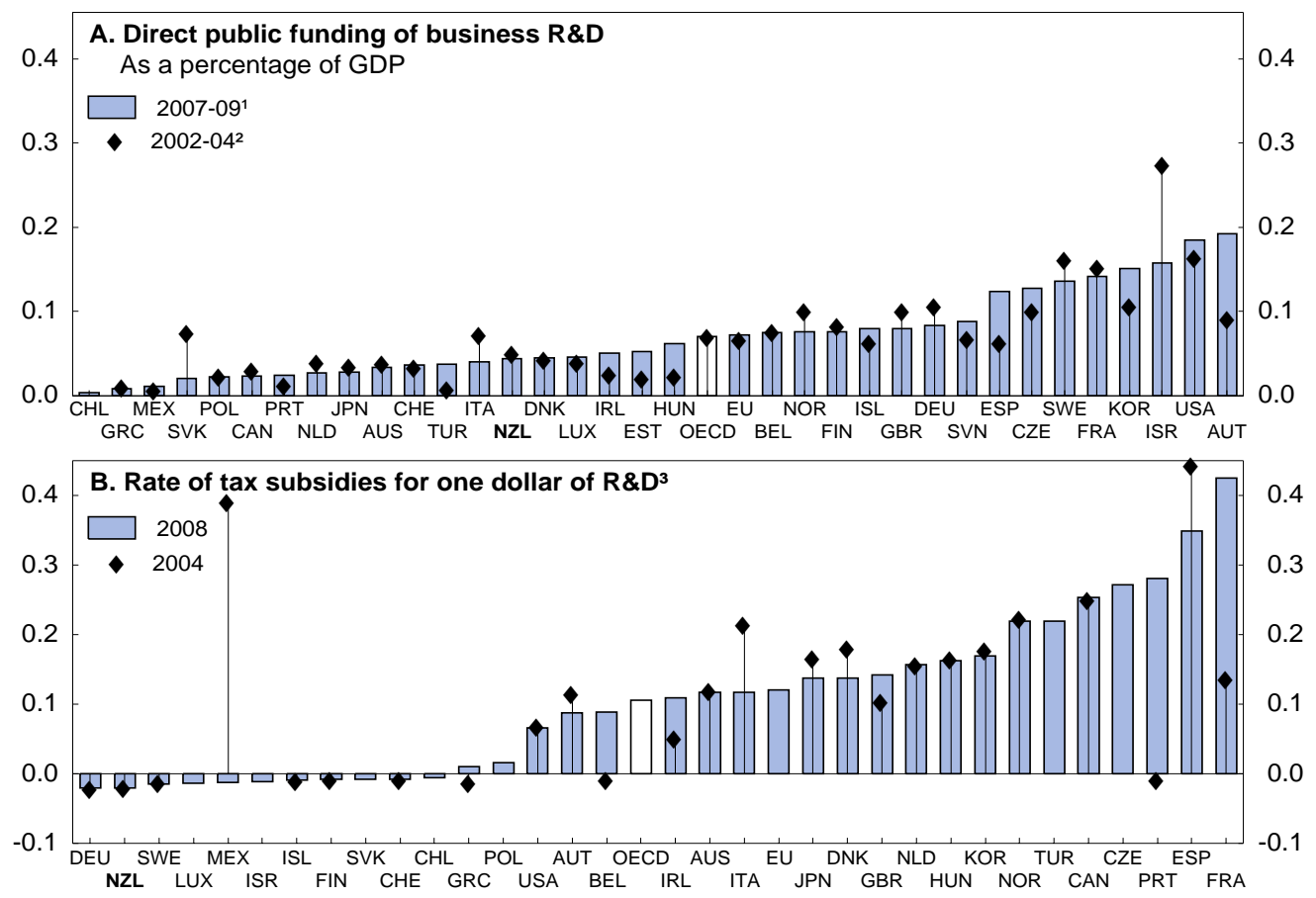

1. 2007 for Greece, Mexico and New Zealand; 2008 for Switzerland.

2. 2003 for New Zealand; 2004 for Switzerland.

3. Measures the generosity of tax incentives to invest in R\&D, on the basis of the pre-tax income necessary to cover the initial cost of one dollar of R\&D spending and pay corporate taxes on one dollar of profit (B-index). A value of zero on the chart would mean that the tax concession for R\&D spending is just sufficient to offset the impact of the corporate tax rate. Average over small and medium enterprises and large firms.

Source: OECD, Economic Policy Reforms 2012: Going for Growth, Figure 3.30. 
The NZ government has taken steps to implement many of the policy recommendations made in the 2007 OECD Review of Innovation Policy (OECD, 2007b) over recent years. Its Business Growth Agenda lays out a clear policy framework for achieving goals across a number of priority areas, including innovation, which aims to coordinate efforts across departments and to bring coherence to a fragmented system of support programmes. A new Ministry of Business, Innovation and Employment was formed in 2012, amalgamating the Ministries of Labour, Economic Development, Housing, and Science and Innovation to promote greater cooperation across different policy areas. Core funding is now provided to Crown Research Institutes (CRIs), whose financing had previously been entirely contestable, allowing a more stable environment for building long-term capabilities. To strengthen the linkages between science and business and improve commercialisation, the government introduced funding to establish two to four National Network of Commercialisation Centres that connect research organisations, incubators, entrepreneurs and regional development agencies. It has also established Callaghan Innovation, a Crown agency aiming to better target research activities in universities and CRIs towards business needs.

The 2007 OECD Review advocated concentrating resources on "better exploitation of potential strengths in niche markets, and commercial exploitation of hotspots of scientific research in which New Zealand has world-class capability" (OECD, 2007b). The government is moving in this direction through significant co-investments with industry to promote research and innovation in the primary sector (Primary Growth Partnership), as well as in high-value manufacturing and services. The biotechnology sector has received strong support from government since the early 2000s and has expanded rapidly to become a major driver of innovation, as indicated by patent applications (Figure 16). It has already contributed substantially to raising productivity in agriculture (Kaye Blake et al., 2006) and has significant potential to become a major source of future productivity gains, export market growth and job creation.

Figure 16. Revealed technological advantage in biotechnologies, 1998-2000 and 2008-101 Index based on patent applications filed under the Patent Co-operation Treaty

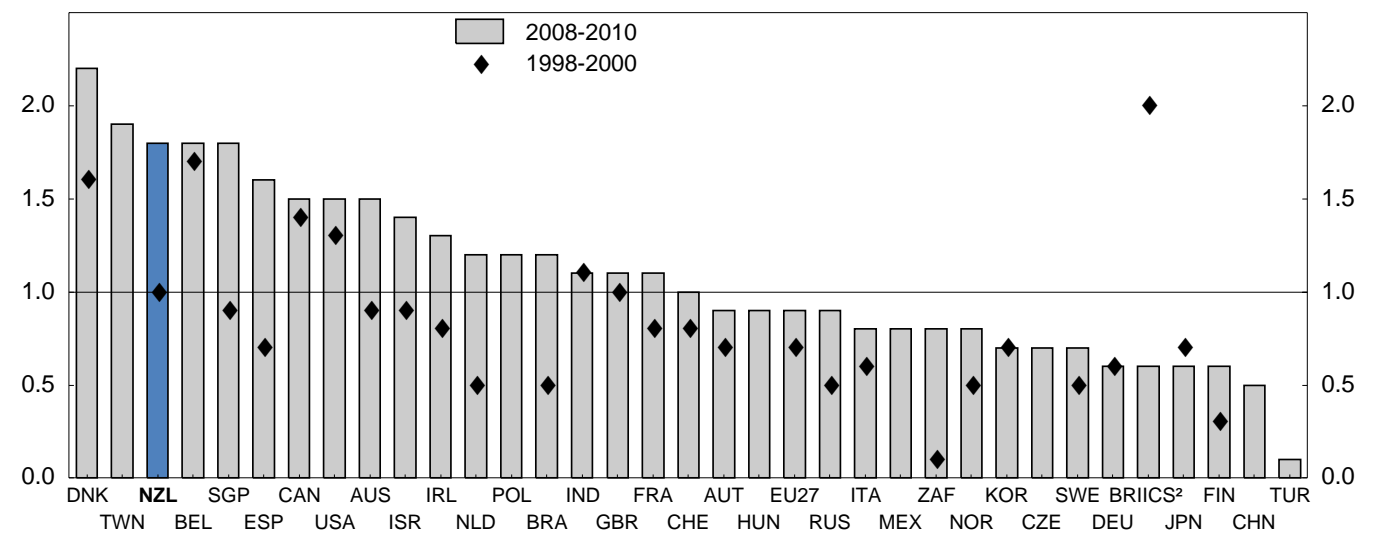

1. The revealed technological advantage index is calculated as the share of country in biotechnology patents relative to the share of country in total patents. Only countries with more than 500 patents in 2007-09 are included in the figure.

2. BRIICS refers to Brazil, Russian Federation, India, Indonesia, China and South Africa.

Source: OECD, Patent Database, December 2012.

Difficulty in accessing capital may be a factor limiting growth of innovative businesses and has likely worsened with increased risk aversion since the onset of the global financial crisis. Furthermore, very few domestic companies rely on equity listing to raise capital, due to the shallow NZ stock market and thin liquidity. The government has established the New Zealand Venture Investment Fund (NZVIF) as a "fund of funds" to help catalyse the development of early-stage capital markets. NZVIF operates through two co-investment vehicles: $i$ ) the Venture Capital Fund, established in 2002 to invest NZD 160 million 
focussing on seed, start-up and early-expansion-stage local firms, and ii) the Seed Co-investment Fund (SCIF), created in 2005 to provide NZD 40 million in matched funding with angel investors to support seed and start-up stage companies. While angel investment has remained strong throughout the financial crisis, the venture capital market shrank significantly, though it is now showing signs of recovery. Given the healthy supply of seed and start-up equity financing, shifting NZVIF's allocation to support more early-expansion stage businesses may help address the financing gap in this area.

Changing the settings of KiwiSaver default providers may also help stimulate domestic equity market development. The six current default funds' terms of appointment require that they adopt a conservative strategy of holding mostly liquid assets and bonds, with little invested in domestic equities. This is because the default funds were originally designed as temporary "parking spots" for new members until they made active investment decisions. However, the majority of KiwiSaver members who had entered a default fund since 2008 were still there in mid-2012 (MBIE, 2012). Changing the default investment strategy to a "life cycle" approach, which maximises retirement income by aligning risk profiles with the member's age, would allow for greater fund allocation towards domestic equity markets; this option is being considered by the government and should be adopted.

Features of the tax system may create uncertainties for potential venture capitalists that impede innovation. For instance, the current lack of a capital gains tax may give rise to ambiguous tax treatment of future asset sales (Lerner et al., 2005): income derived from the sale of assets is not taxable if acquired for the intent of long-term investment but is fully taxable if acquired for the purpose of profiting from resale. Uncertainty over how individual venture capital investments will be classified for tax purposes may be a significant deterrent for investors. In the absence of a capital gains tax, these tax distinctions should be elucidated and clearly communicated to potential investors.

Compared to other OECD countries, New Zealand's tax treatment of intangible assets is not particularly conducive to attracting capital to innovative companies. For example, as in other OECD countries, patents are treated as depreciable assets rather than expenses that can be deducted in the year costs are incurred. However, most OECD countries provide some tax benefits to patenting activity by allowing accelerated depreciation, but New Zealand is one of the few countries that does not (Warda, 2006). Furthermore, many countries provide tax credits for the R\&D expenditures that contributed to the invention, but New Zealand repealed its R\&D tax credit in 2009. Finally, unlike other assets in New Zealand, the tax code treats the entire proceeds from a patent sale as taxable income, rather than just the gain. This inconsistent tax treatment may create distortions in investment behaviour, and the undepreciated capital cost should be netted out from the sale proceeds for taxation purposes. These tax settings are currently under government review.

Because intellectual capital is highly mobile, policies such as patent boxes (whereby patent earnings are taxed at a lower rate) and $\mathrm{R} \& \mathrm{D}$ tax credits can have a large influence on where multinational corporations decide to locate investment activities. In this respect, New Zealand's geographical disadvantage is magnified by its lack of favourable tax treatment for R\&D and patents. Admittedly, however, it is not clear that engaging in fierce tax competition would attract sufficiently large amounts of capital to a small and remote country to be worth the fiscal cost. Much of New Zealand's low R\&D intensity may be explained by its industrial structure and distance from large markets (Crawford et al., 2007). Nevertheless, some tax relief targeted at R\&D may help prevent existing activity from moving overseas. Allowing more rapid depreciation of the costs of patenting for tax purposes may also help to "actively encourage more multi-national companies to conduct research in New Zealand", as stated in the government's Business Growth Agenda.

Doubts about how much additional R\&D a tax credit could generate, combined with concerns over the fiscal and compliance costs during an economic downturn, led the new government to cancel it after 
only one year of operation. Nonetheless, public support for business-sector R\&D is low by OECD standards and will need to be increased if the government is to achieve its ambitious goal of doubling the level of business expenditures on R\&D to over $1 \%$ of GDP. To replace the R\&D tax credit, the government has introduced Technology Development Grants (TDGs) (Box 2) to support technology-intensive firms. The grants provide NZD 60 million in funding per year to support business $R \& D$, roughly $16 \%$ of the estimated annual fiscal cost of maintaining the R\&D tax credit. In the first year of operation, one third of applications were approved, and the programme had been significantly over-subscribed until the most recent year. Furthermore, some discretionary judgment is required to allocate the funds, which reduces transparency and increases the administrative burden and compliance costs. Compared to a broad-based tax credit, the grant contains public costs through more targeted support, which may facilitate the immediate task of fiscal consolidation. However, because TDGs are accessible only to firms with a history of R\&D, it places potentially innovative technology start-ups at a disadvantage. The government is currently reviewing the grant scheme and should redesign it to improve transparency in the approvals process and ensure access to new innovative enterprises. Once fiscal space becomes available in the future, it may be worth considering re-instating a more transparent, broad-based and administratively efficient refundable tax credit, but care must be taken to maintain some policy stability in this area.

\section{Box 2. New Zealand's Technology Development Grants (TDGs)}

Introduced in 2010, TDGs offer support over three years, funding $20 \%$ of eligible expenditures of a business's R\&D programme, with up to NZD 2.4 million per business per year. To be eligible for funding, firms must be resident in New Zealand, have an R\&D intensity of at least $5 \%$ of revenue, and revenue of at least NZD 3 million per year over the previous three years.

In addition to eligibility criteria, proposals are assessed against four subjective judgment criteria, according to various weights (in brackets):

- The business must have a successful track record in delivering and exploiting R\&D, and meet due-diligence requirements to a high standard, including financial viability and management capabilities (40\%);

- $\quad$ The business must have ambition to grow through investment in R\&D (15\%);

- $\quad$ The R\&D programme must align with business growth aspirations (15\%); and

- $\quad$ The R\&D programme must generate wider benefits to New Zealand (30\%).

\section{Improving human capital}

Expanding the supply of skilled labour will be necessary to increase the contribution of knowledge-based activities in the economy and promote sustainable, inclusive growth. The compulsory-school system performs very well on average based on relatively strong PISA scores, and tertiary attainment rates are among the highest in the OECD. However, these statistics mask a very wide distribution of educational achievement among youth (Bibbee, 2013) as well as low completion rates at the upper-secondary level (OECD, 2012b). While participation in vocational education is exceptionally high, university participation rates are close to the OECD average, with completion rates well below the average (Zuccollo et al., 2013).

As part of the Business Growth Agenda, the government is more clearly signalling the importance of pathways through which young people can gain the qualifications needed to move into employment and develop higher-level skills. It has set two broad educational goals to achieve by 2017: $i$ ) to raise the proportion of 18 year-olds with a National Certificate of Educational Achievement (NCEA) qualification 
level 2 (equivalent to a secondary school diploma) from the current $72 \%$ to $85 \%$; and $i$ ) to increase the proportion of 25-34 year-olds with NCEA level 4 or above (a one-year Polytechnic advanced trade certificate) from $52 \%$ currently to $55 \%$.

The potential impact on long-term growth of achieving both of these targets can be estimated using the OECD long-term projection model. The model defines the stock of human capital based on the average years of schooling across the working-age population, combined with a simple assumption of diminishing returns to schooling. A crude assumption is made for modelling purposes that achieving NCEA level 2 qualification translates into 12 years of schooling and level 4 into 14 years of school. New Zealand's human capital stock is then constructed by aggregating the years of schooling across age groups, weighted by the population shares. Most recent 2006 census data suggest that the average years of schooling in New Zealand's working-age population is 12.8 years, roughly equivalent to the amount of time spent to achieve NCEA level 2-3 qualifications. According to this data, the cohort with the most years of schooling is the 25-34 age group, at 13.8 years. In the baseline scenario, policies are assumed to remain unchanged, and each cohort keeps the same level of schooling obtained at ages 25-29 for the remainder of their lives; natural ageing results in an increase from 12.8 to 13.5 average years of schooling for the working-age population by 2060 . Meanwhile, in a scenario where the government implements policies to achieve its targets for educational attainment (with no further changes beyond 2017), the difference in years of schooling relative to the baseline is minimal, about 0.07 additional years on average by 2060 . As a result, the projected impact on potential output growth is also very small, peaking at 0.02 percentage points in 2017 before diminishing thereafter (Figure 17, Panel A).

Figure 17. Projected real GDP impact of educational reforms
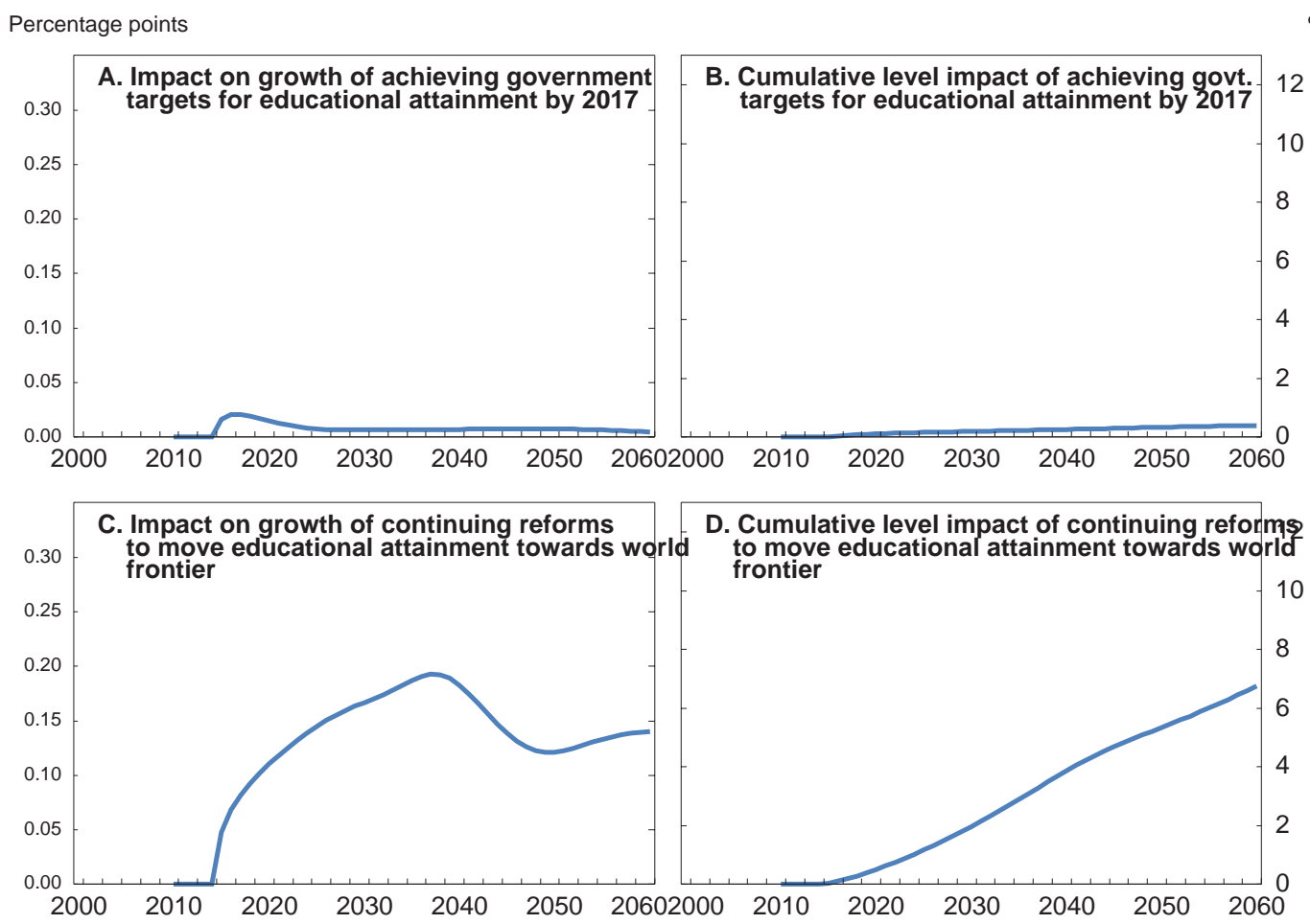

Source: OECD calculations.

Meanwhile, if it is instead assumed that policy reforms continue to raise the educational attainment of 25-29 year olds beyond 2017 towards the world frontier (Korea), the estimated gains would be more 
substantial. Lifting the average years of schooling of the working age population by one additional year (relative to the baseline) by 2060 might add as much as 0.15 percentage points to real output growth and up to nearly $7 \%$ to the level of GDP over the long run (Panel D). These estimates are highly uncertain, however, given the very crude measure of human capital being used. Furthermore, the true impact depends heavily on the extent to which the skills being acquired are employable in the economy.

The effect of enhanced skill levels on growth will depend on whether those skills are demanded and sufficiently valued by the domestic labour market. The rewards to investing in higher education may be relatively weak in New Zealand, and the potential reasons are discussed in Bibbee (2013). Relatively low private returns to higher education are probably related to the economy's poor productivity performance and may explain the large outflows of skilled workers in search of better earnings prospects abroad. Migration flows shape the stock of human capital considerably in New Zealand, with immigrants tending to be more skilled on average than the native-born population (Dumont and Lemaitre, 2005). Furthermore, the probability of emigrating appears to increase with the level of educational qualification (Papadopoulos, 2012). The population share of the country's skilled diaspora is among the largest in the OECD, with almost one quarter of tertiary-educated New Zealanders living abroad, almost $80 \%$ of whom live in Australia. In 2008, New Zealanders doing similar jobs in Australia earned on average 19\% more in real terms than those remaining at home (Stillman and Velamuri, 2010).

High-skilled emigration undermines the economic and social benefits from the public investment made in education. Furthermore, tertiary graduates who leave the country are not required to repay their student loans as long as they remain overseas, but they do accrue interest on those debts during their absence. In contrast, graduates who remain at home do not pay interest on student loans but must make income-contingent repayments. The growing debts that await overseas graduates may at the margin create disincentives to returning home. The government is currently exploring options to track down overseas student debtors. Since the majority of tertiary-educated emigrants live across the Tasman, it would be worthwhile to collaborate with the Australian tax authorities to enforce the same repayment obligations on $\mathrm{NZ}$ student debtors working there as those who remain at home.

The implied loss of human capital via emigration is offset to a great extent by the large inflows of highly skilled migrants, representing a "brain exchange" rather than a "brain drain". Immigrants account for almost one quarter of the country's population, the fifth largest share in the OECD. NZ immigration policy targets high-skill individuals through a points system similar to Australia's and Canada's (Box 3), with strong links to the labour market. However, analysis by Stillman and Maré (2009) finds that newly arriving immigrants experienced employment rates on average 20 percentage points below those of comparable native-born individuals and, when employed, tended to earn 10-15\% lower hourly wages. These outcomes may reflect lower average English literacy and numeracy skills of immigrant degree holders compared to those born in the country (Smyth and Lane, 2009). However, this employment shortfall tends to disappear after 10-15 years, while the wage gap narrows considerably and even vanishes for university-qualified immigrants. This pattern of convergence appears to compare favourably to that of other OECD countries, and more generally New Zealand fares better than most in integrating its immigrants (OECD, 2012d). Meanwhile, immigrants who arrive before the age of 18 experience labour-market outcomes no different from those of comparable native New Zealanders (Stillman and Maré, 2009).

While immigration can help offset the economic impact of population ageing by targeting younger people, gains in its contribution to growth may be limited in the future. Attracting foreign talent may become more difficult as more and more countries, particularly in Asia, shift towards higher value, knowledge-based activities. Moreover, immigrants often bring with them older family members. Nonetheless, the ageing workforce and high rates of emigration suggest it would be worthwhile to continue efforts to attract high-skilled immigrants to maintain a competitive and dynamic economy. 


\section{Box 3. Immigration policy in New Zealand}

New Zealand first adopted a points system for accepting immigrants under the Immigration Amendment Act 1991, whereby applicants were selected if they attained a set minimum number of points, which were awarded for employability, age, educational qualifications and settlement funds. Beginning in 2002, minimum standards for English-language ability were set to the level required of students entering university. In 2003 the pass mark system was replaced by a process that placed applicants with a certain level of points into a selection pool. A skilled migrant category was introduced, whereby applicants are allocated points based on identified skills shortages in the economy. Applicants that fulfil the requirements for an occupation on the immediate skills-shortage list may be eligible for a temporary work visa, whereas those qualified for an occupation on the long-term skills-shortage list may be considered for both temporary and permanent residence grants (after two years). About $60 \%$ of residence places are granted to skilled/business migrants, with the remainder under humanitarian and family-sponsored categories (New Zealand Treasury, 2009b).

The link between temporary and permanent migration is exceptionally strong in New Zealand (Hodgson and Poot, 2010) - the skilled migrant category prioritises the selection of temporary foreign workers either currently employed in the country, with NZ work experience or with job offers, in order to maximise employment outcomes (a so-called two-step migration process). Such onshore skilled migration accounted for $83 \%$ of primary applicants for immigration in 2008-09. This contrasts with only $35 \%$ in Australia, where the majority of onshore applicants are former international students. In this respect, New Zealand's points system has historically placed a heavier emphasis on potential labour-market integration (especially favouring areas of skills shortage) and required a higher minimum standard of English than Australia. Meanwhile, New Zealand weights less heavily the age of its migrants, with points awarded to applicants aged 20-55 (more for the youngest), compared to 18-44 in Australia (recently extended to 49).

\section{Skills for innovation}

Skills play an essential role in driving innovation, especially in the areas of science, technology, engineering and mathematics (STEM). New Zealand produces a comparatively low proportion of engineers at the tertiary level relative to other subjects, although it graduates a relatively high share in the sciences (Figure 18). Similarly, at the secondary level, the percentage of 15 year-olds aspiring to engineering careers is about half the OECD average (OECD, 2012b). To address concerns about a long-term shortage of engineering skills in the country (IPENZ, 2010), the government announced it will provide NZD 42 million over four years to increase tuition subsidy rates for engineering students and raise the number of engineering graduates by 500 per year by 2017. The extent of the current skills shortage in engineering is not clear, however. A government analysis reveals that tertiary education enrolments and

\section{Figure 18. University graduates by field of study}

Per thousand population, 2010

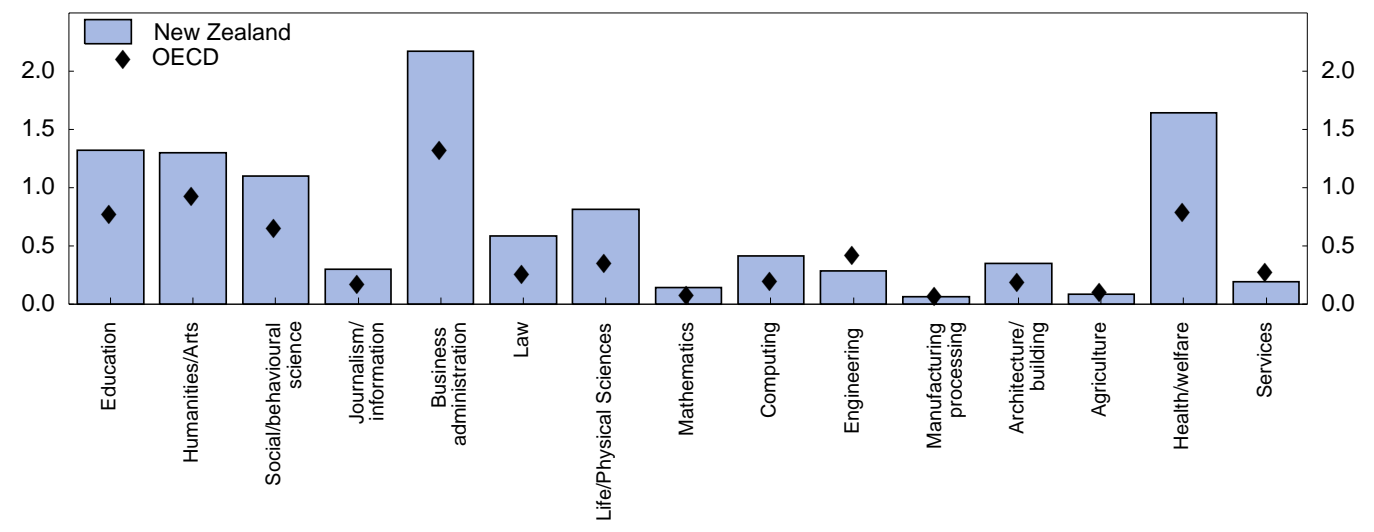

Source: OECD, Education database. 
completions in engineering increased at a faster pace on average than all other fields between 2001 and 2007 (Department of Labour, 2008). Moreover, salaries for engineers grew at the same pace as the rest of the labour market in 2005-07, indicating little evidence of demand pressures. However, it may be that firms have been unwilling to pay the higher wages needed to fill their skills shortages (Bibbee, 2013). Although the planned funding increases may encourage enrolment in engineering, they do not guarantee that graduates will fill industry needs or even remain in the country. NZ engineering salaries are very low by international standards, comparable to those in emerging market economies (Department of Labour, 2008).

Furthermore, employers have expressed dissatisfaction with the practical experience possessed by the stock of engineering graduates in the country (Department of Labour, 2008). To encourage the development of engineering skills the government should consider promoting stronger academic-industry linkages and practical training. This could be done through support for student internship opportunities and improved career placement services within tertiary engineering faculties. Such efforts may reap more valuable benefits especially if concentrated in the engineering clusters, such as those in Dunedin and Taranaki.

\section{Countering the effects of ageing on growth}

Across most OECD countries, population ageing is expected to significantly affect long-term growth, fiscal sustainability and saving-investment balances. A slower expansion of the working-age population is likely to depress future growth but may be countered by measures to increase the participation rates of older workers. OECD analysis suggests that older workers' participation depends significantly on the legal age for receiving full retirement pensions, the implicit tax on continued work and the health status of older workers (Johansson et al., 2013). In New Zealand, seniors' employment rates are higher than in most other OECD countries (Figure 19, Panel A). Moreover, their participation rates have been increasing at a much faster pace than the OECD average since the early 1990s (Panel B). Improving health outcomes can explain part of this increase, given the extension in life expectancy of 4-5 years over this period. In addition, pensioners' participation rates tend to increase with educational qualifications (Khwaja and Boddington, 2009). However, financial incentives provided by changes in retirement-income policies have likely played a much more prominent role (Gorman et al., 2012). These changes include the abolition of the mandatory retirement age in 1999 and a phased increase in the age of public-pension eligibility from 60 to 65 years between 1992 and 2001. During this period, participation rates of the 60-64 age group more than doubled (and have continued to rise), and a notable upward trend shift can be seen for the 65+ group as from 1998 (Panel B).

The high participation rates of older New Zealanders probably also reflect features of NZ Superannuation (NZS), the universal public pension system, which tends to discourage early retirement by providing very limited access before the age of 65 (New Zealand Treasury, 2009a). NZS serves as the primary source of retirement income for many, due to a tradition of low private saving and household preferences for holding real rather than financial assets (Hurnard, 2005), although this may change with the recent introduction of alternative superannuation schemes, such as KiwiSaver. While public income support may be available to those who retire before age 65 in the form of unemployment and disability benefits, it is subject to qualifying conditions and provided at a lower rate than NZS. The lack of early retirement options has tended to create a strong link between the official age of pension eligibility and the age at which most residents choose to retire.

Because NZS pays a flat rate to all who reach age 65 regardless of whether they remain employed, the implicit tax on continued work at older ages is one of the lowest in the OECD (Figure 20). This feature also implies that incentives to retire at the pensionable age depend heavily on pre-retirement earnings: retiring at 65 is financially attractive for those with low earnings who therefore face minor opportunity costs of stopping work. Empirical analysis suggests that being eligible for NZS reduces male labour force 
participation rates by 21 percentage points; female participation rates drop by 7 percentage points at the age of eligibility and by 11 percentage points in the preceding few years (Hurnard, 2005). Meanwhile, those with higher income face lower incentives to retire at the pensionable age, but working part time may become more attractive. Indeed, most recent (2006) census data indicate that 52\% of employed New Zealanders over the age of 65 were working part time.

Figure 19. Labour force participation rates of older workers

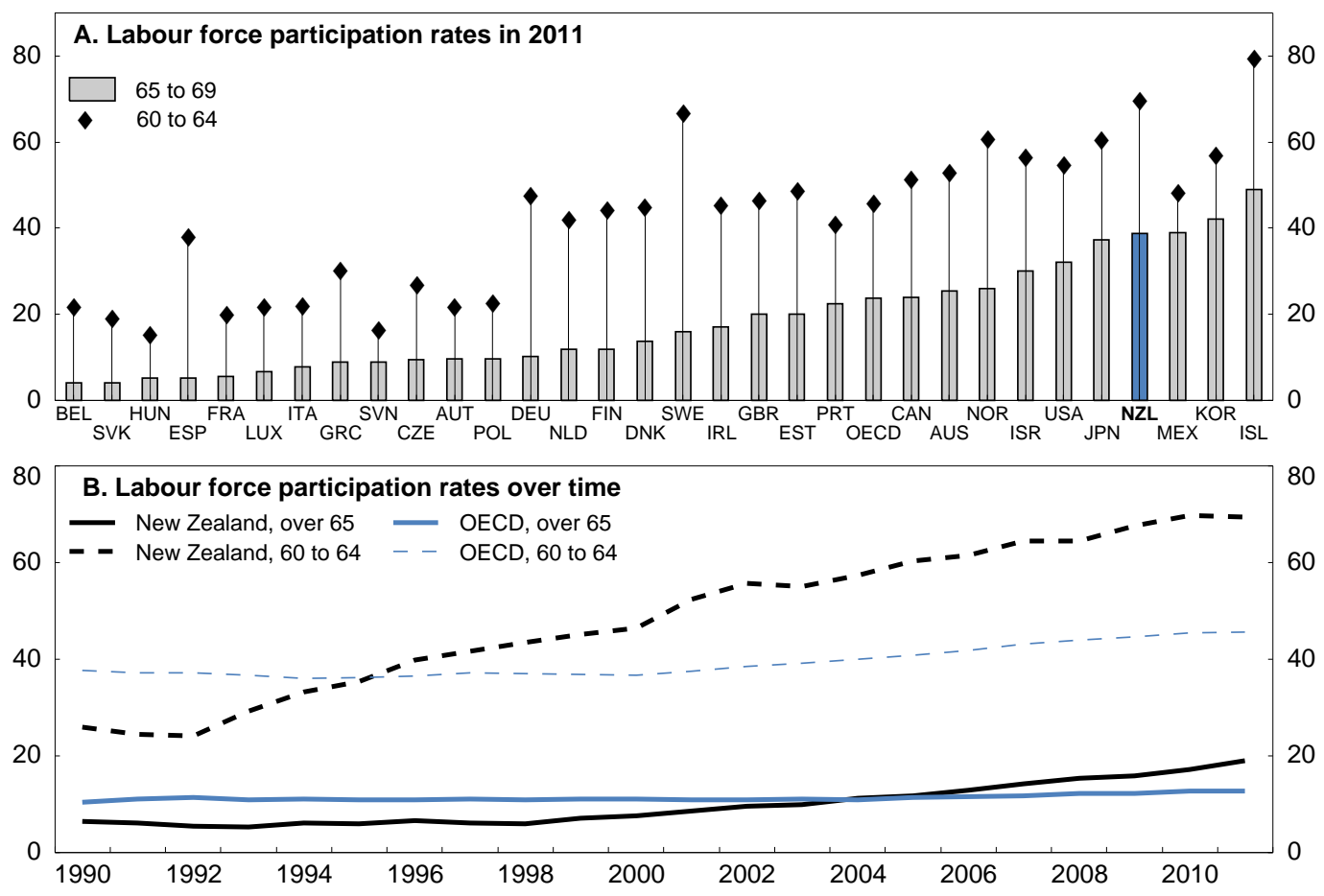

Source: OECD, Labour Force Statistics database.

Figure 20. Implicit tax on continued work: old-age pensions ${ }^{1}$

2009 , percentage of average worker earnings

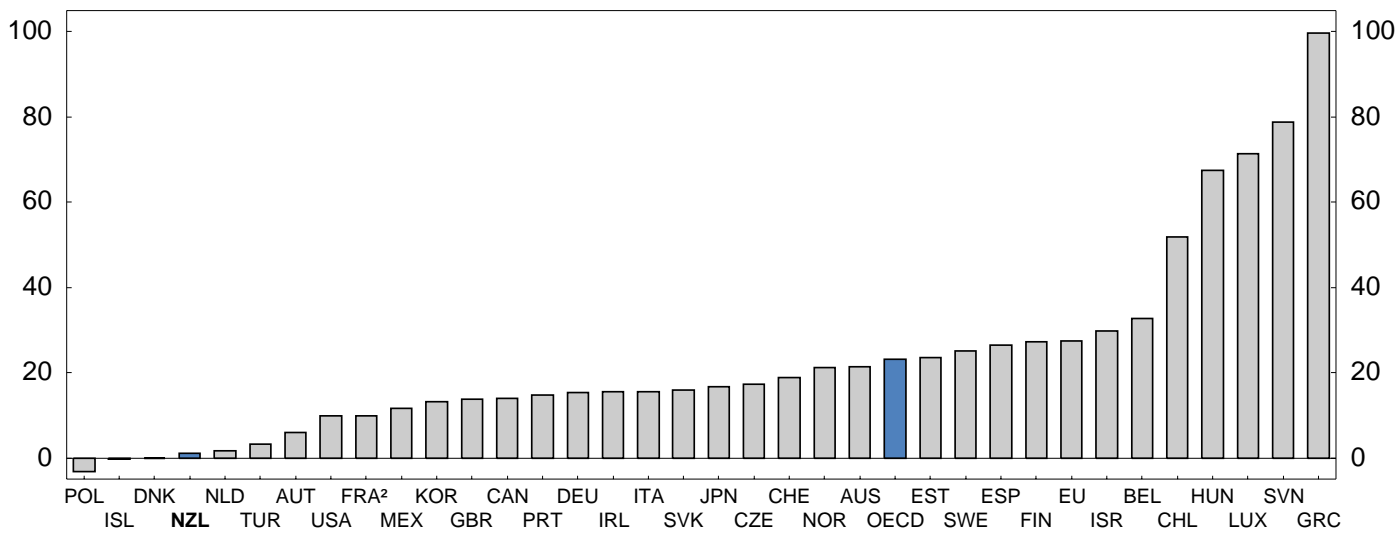

1. Implicit tax on continued work in regular old-age pension system for 60 year-olds.

2. For France, year 2010.

Source: OECD, Economic Policy Reforms 2012: Going for Growth, Figure 3.5B. 


\section{Impact of increasing the pensionable age}

These considerations suggest that raising the age of pension eligibility is likely to increase the participation rates of older workers substantially. Ideally, this would be done by linking the age of eligibility to life expectancy. If policy remains unchanged, OECD model projections suggest that demographic ageing would push the aggregate labour force participation rate down from $68 \%$ in 2012 to about $63 \%$ in 2060 , assuming older workers continue to work in line with historical behaviour. In contrast, if the pensionable age were to increase in line with longevity, so that the number of years individuals spend working (i.e. their "active lives") lengthens proportionally with their expected lifetimes, the projected total labour force participation rate would instead increase to almost $70 \%$ by 2060 (Figure 21). In this scenario, the participation rates of those older than 65 would more than double from $17 \%$ in 2012 to over $40 \%$ in 2060. The average life expectancy is projected to rise from 80 years in 2012 to 86 years in 2060, and the average time spent working would rise by 2-3 years. Such a change would increase projected average annual output growth in the long run by 0.4 percentage point and the level of GDP by almost $10 \%$.

Figure 21. Projected impact of raising the pensionable age in line with life expectancy

Percentage

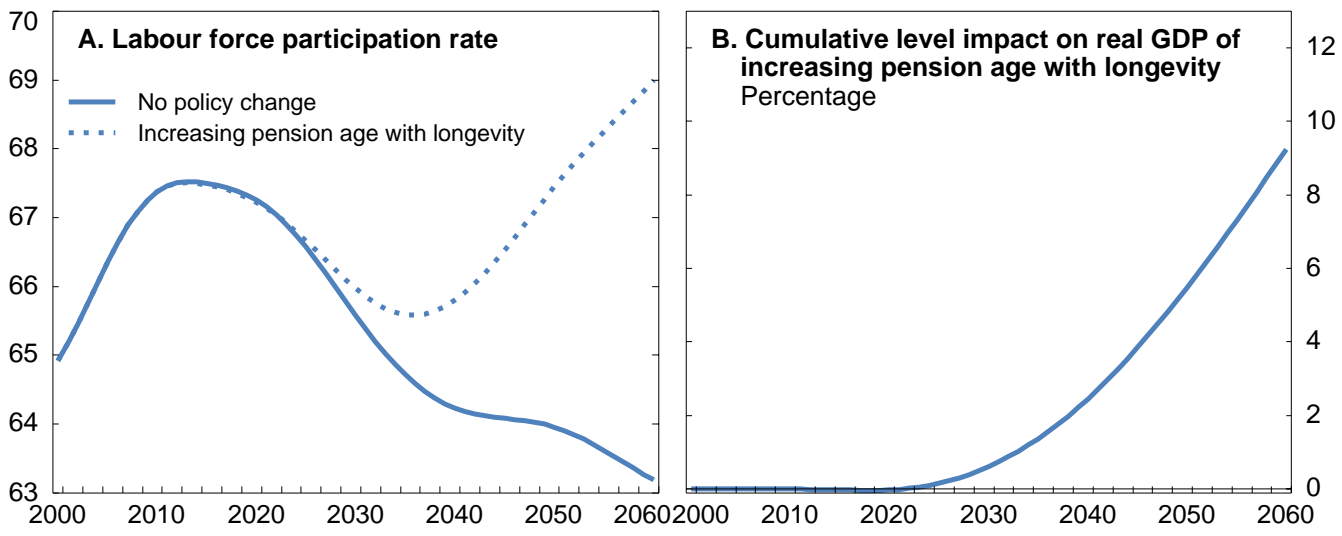

Source: OECD calculations.

It is likely that these projected impacts of raising the pensionable age may be overoptimistic, in part because they assume "healthy ageing", i.e. the gains to longevity are all treated as years in good health. Additionally, because those who already continue to work beyond age 65 tend to be the higher skilled and more productive workers, raising the pensionable age may serve to keep some less productive workers in the labour force for longer, while shifting others onto unemployment or disability benefits.

\section{Correcting large macroeconomic imbalances that may harm long-term growth}

New Zealand has long grappled with the persistence of wide external deficits, associated with low domestic saving, a high cost of capital and an overvalued exchange rate. Net foreign liabilities have trended higher for several decades and were estimated to have reached 95\% of GDP at the peak of the housing boom in 2006. They have since fallen back to about $70 \%$ of GDP, but much of this decline may reflect cyclical factors and the transitory effects of reinsurance claims following the Canterbury earthquake. Large imbalances may cause a prolonged and marked drag on economic activity if they undermine confidence in financial prospects and dampen business investment (André, 2011). They may also distort the overall structure of the economy, with possible adverse consequences for long-term growth (Lane, 2011). For example, large net capital inflows arising from strong domestic demand pressures have probably contributed to a real exchange-rate appreciation and squeezed the domestic tradables sector. A shrinking trade sector may have long-term effects on growth, if financial constraints make capacity losses 
in export sectors difficult to reverse (Blanchard, 2007). Furthermore, "learning-by-doing" effects may cause a period of lower exporting activity to permanently harm productivity levels in the traded sector (Lane, 2011).

Analysis by Cecchetti et al. (2011) based on a panel of 18 OECD countries suggests that very high levels (above $85 \%$ of GDP) of public and private non-financial debt are damaging to growth, with larger effects from government debt. In addition, high levels of private debt create risks for public-sector debt and vice versa. When private borrowing has public guarantees, default increases public debt - whereas the government's ability to sustain a given debt level depends on its ability to raise revenue, which may shrink if the private sector is heavily indebted. These results support a prudent strategy of aiming for debt levels well below these estimated thresholds to provide a buffer for shocks that push debt to damaging levels.

In New Zealand's case, low domestic saving relative to desired investment have helped keep real long-term interest rates higher than in most other OECD countries since the 1990s, pushing up the cost of capital and restraining business investment. The lack of domestic savings has resulted in a dependence on foreign capital and borrowing from abroad. Some outside observers have alternatively suggested that relatively high real interest rates may reflect a risk premium associated with the country's large stock of net foreign debt and the expectation of future real exchange-rate depreciation (Lane, 2011; Burnside, 2011). Indeed, the size of a country's net foreign assets is found to significantly affect real interest rate differentials (see Annex 1), although this does not necessarily reflect overseas investors demanding a risk premium to compensate for higher risk associated with larger external debt burdens. A significant portion of New Zealand's foreign borrowing is between parent and subsidiary banks, which may be less risky. Furthermore, as argued by Labuschagne and Vowles (2010), such a risk premium would probably lead to higher domestic saving and a lower exchange rate over time, which has not been the case in New Zealand.

\section{The impact of a higher public saving rate over the long term}

As recommended in the 2011 Economic Survey, reducing external vulnerabilities will require not only structural reforms to encourage private saving, but fiscal policies that raise the level of public saving over the long term and provide a buffer against macroeconomic shocks. The NZ Treasury is currently examining different policy options to move to a sustainable debt path in preparation for its next long-term fiscal statement to be published in mid-2013. One potential "sustainable debt scenario" is explored in Bell (2012), which would stabilise "core Crown" net debt (which includes only central government liabilities and excludes NZ Superannuation Fund assets) at 20\% of GDP by 2025 and onwards. This scenario would require small general government deficits of on average $0.4 \%$ over 2015-2060. Assuming net capital expenditures evolve in line with their historical average and local governments maintain balanced budgets, this would translate to central government operating surpluses of on average of $1.9 \%$ of GDP for the decade from 2014-15, followed by surpluses averaging 1.3\% of GDP to 2060 .

In the OECD model, changes in fiscal policy affect long-term growth through an interest rate risk premium that is imposed when government debt levels exceed $75 \%$ of GDP (Box 1). Fortunately, New Zealand's public debt levels are not high enough to impinge on future growth prospects. To explore the potential impact that the above "sustainable debt" scenario may have on long-term growth, a simplifying assumption is made for the sake of modelling purposes that fiscal policy may also affect growth through its impact on external imbalances, which markets penalise via an additional interest-rate risk premium. The OECD model's equation for long-term interest rates in New Zealand is thus adjusted to incorporate a risk premium that varies with changes in net foreign assets, according to the estimated relationship described in Annex 1.

The baseline (Table 1) already assumes a benign scenario in which fiscal policy adjusts to stabilise the gross debt ratio over the long term at about $56 \%$ of GDP and that any ageing-related pressures on health 
spending are offset through budgetary reforms (Box 1). The "sustainable debt scenario" of Bell (2012) implies only slightly higher fiscal balances in the long run than in the baseline scenario (Figure 22, Panel A), which results in a gross debt ratio of $49 \%$ of GDP by 2060 . About $40 \%$ of the increase in public saving is assumed to be offset by lower private saving through Ricardian effects. The positive effect on national saving rates is largest over the first decade, reducing the current account deficit by about 1 percentage point of GDP in 2020 relative to the baseline, but by only 0.2 point of GDP by 2060 (Panel B). The impact on long-term interest rates is derived by assuming that the level of net foreign assets changes by the amount of the current account each year (with no change in valuation effects), and the risk premium evolves accordingly. The model simulations suggest that this "sustainable debt scenario" would not change potential output much relative to the baseline: by 2060, real long-term interest rates are lower by about 0.2 percentage point (Panel C), and the impact on real output is very small (Panel D). However, this scenario would probably also result in a lower exchange rate, whose effects are not taken into account in these estimates. Furthermore, the reduction in external vulnerabilities is noteworthy, with net foreign debt almost 12 percentage points of GDP lower (almost one standard deviation) by 2060.

Figure 22. Projected impact of policies to reduce core Crown net debt to $20 \%$ of GDP by 2020
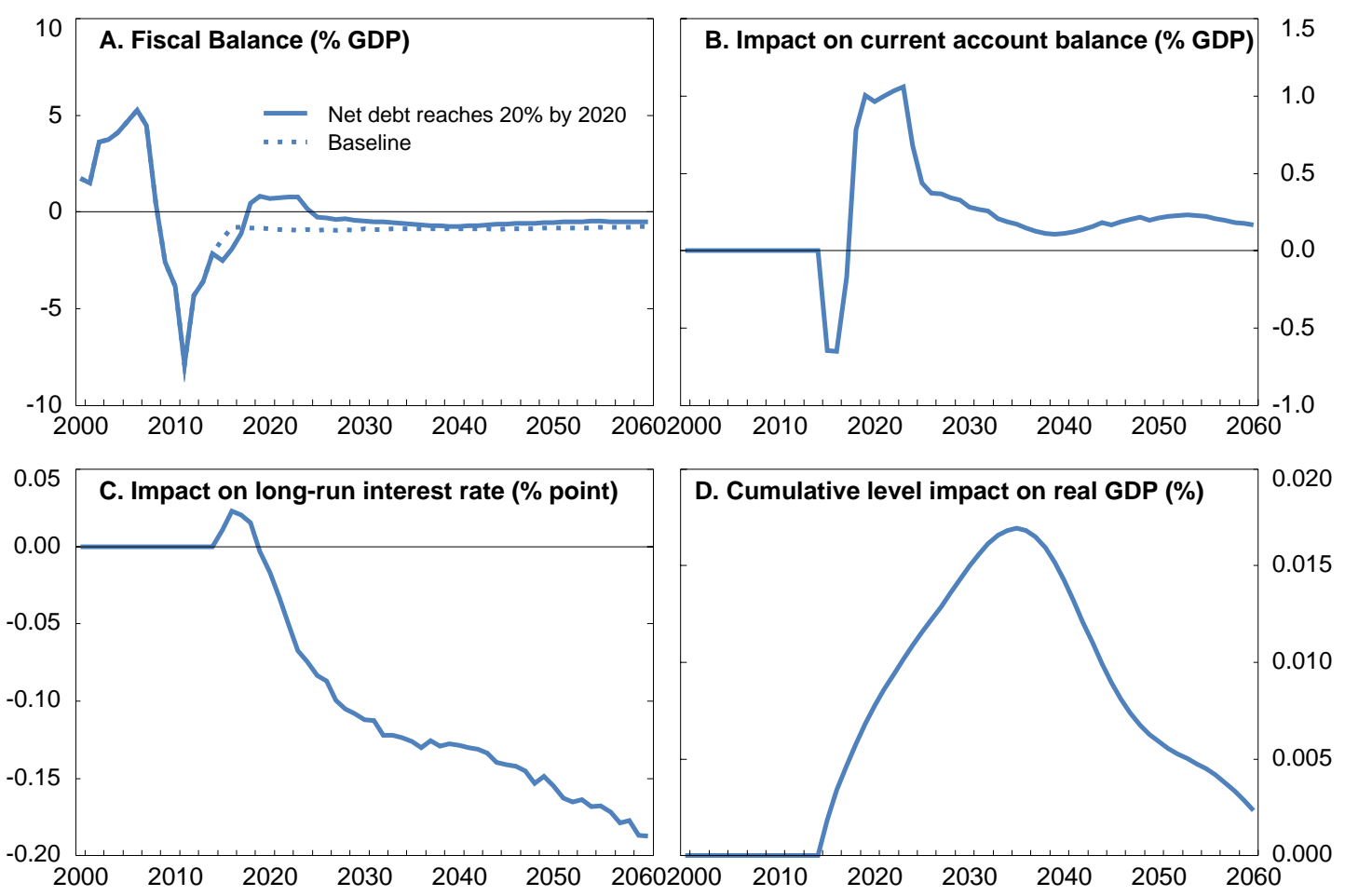

Source: OECD calculations.

\section{Managing natural capital and climate change}

The sustainability of economic growth depends on the importance of non-renewable natural resource extraction for overall income generation and the rate at which environmental capital is permanently degraded in the process. Along with labour, physical and human capital, natural assets such as minerals, fossil fuels, land and water are used and depleted in the production process. Natural capital plays a particularly important role in New Zealand's economy relative to its peers (Figure 23), and protecting this base is discussed in the in-depth chapter on green growth of the 2011 Survey. Furthermore, economic activity produces negative externalities in the form of pollution and climate change that can worsen 
productivity, biodiversity, agricultural yields, human health and overall well-being. Devoting resources to reducing these externalities can enhance long-term production possibilities and living standards, but at a cost to market output in the short term. Traditional measures of productivity growth that do not take environmental damage into account may therefore overestimate a country's long-term growth potential.

Figure 23. Total wealth per capita

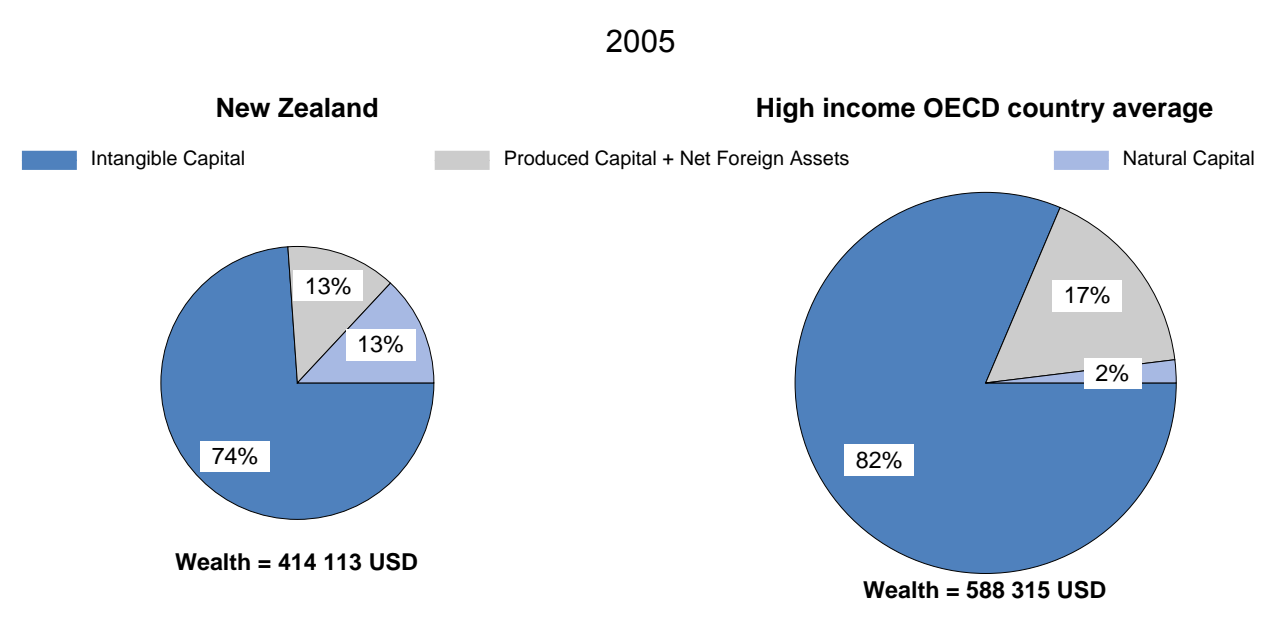

Source: World Bank (2011), The Changing Wealth of Nations database

Recent OECD work addresses this issue by constructing "green" productivity measures that adjust the productivity measurement framework for both the use of natural resources in production as well as undesired outputs (Brandt et al., 2013). The latter include greenhouse gas (GHG) emissions, air pollution and nitrogen balances (which indicate the amount of nitrogen that is released into the environment as a result of excessive fertiliser use in agriculture). This analysis shows that when the natural resource inputs of land, forestry and sub-soil assets (such as oil, gas, coal and minerals) are incorporated into the production function, estimated annual MFP growth for New Zealand is about 0.2 percentage points higher on average over the 1985-2008 period. The positive adjustment appears to reflect increasingly efficient use of land, as agricultural output has grown rapidly, while the use of land as an input factor has hardly increased over the investigated period. However, a sharp negative correction to MFP growth occurs in 2007-08 due to faster growth in oil and gas extraction in those years (Figure 24) in response to higher energy prices.

Meanwhile, GHG emissions rose at only a slightly slower pace than output over the 1990-2008 period, resulting in very little additional adjustment to effective MFP growth. These results suggest that the efficiency with which natural capital is used in New Zealand's production has been stable or even increasing over time. Yet, that does not imply that income generation has caused no damage to the environment. On the contrary, further progress is needed. Growth in GHG emissions was the third highest in the sample of 22 OECD countries, as about half of these countries saw their emissions decline in this period. Furthermore, nitrogen balances increased the most among OECD countries between 1990 and 2008 (Figure 25), pointing to growing pressures on water quality. 
Figure 24. Productivity growth adjusted for natural capital inputs and bad outputs

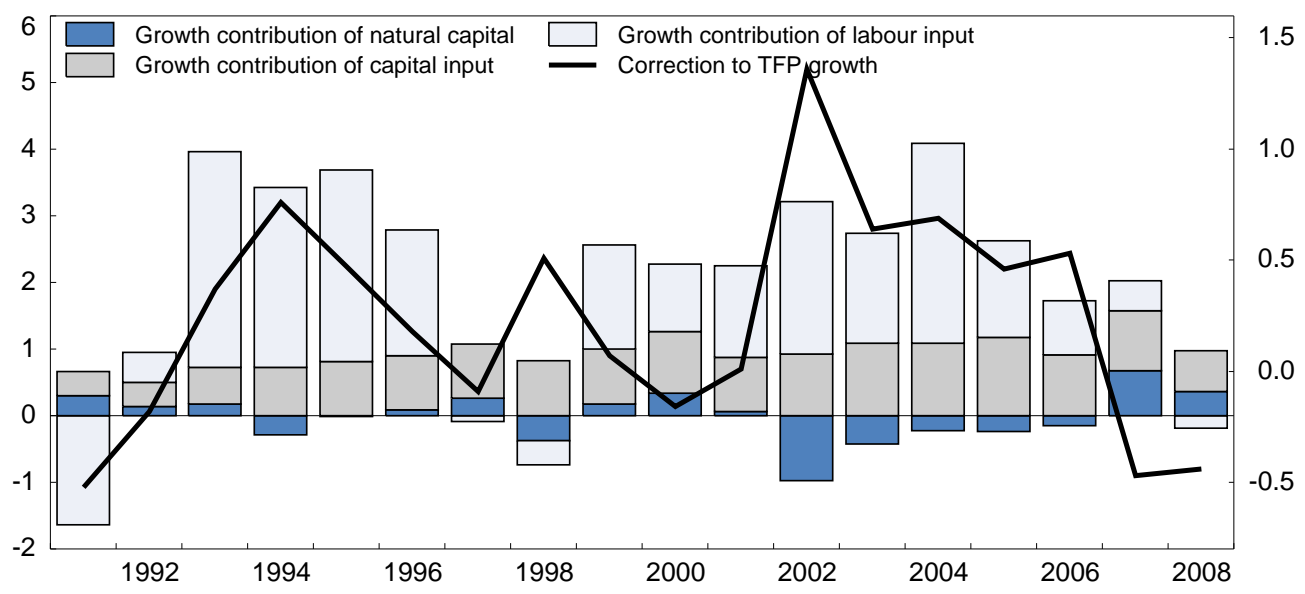

Source: Brandt et al. (2013), "A green productivity measure”, OECD Economics Department Working Papers, forthcoming.

Figure 25. Level and change in nitrogen balance, 1990-2009

Kg per hectare of agricultural land

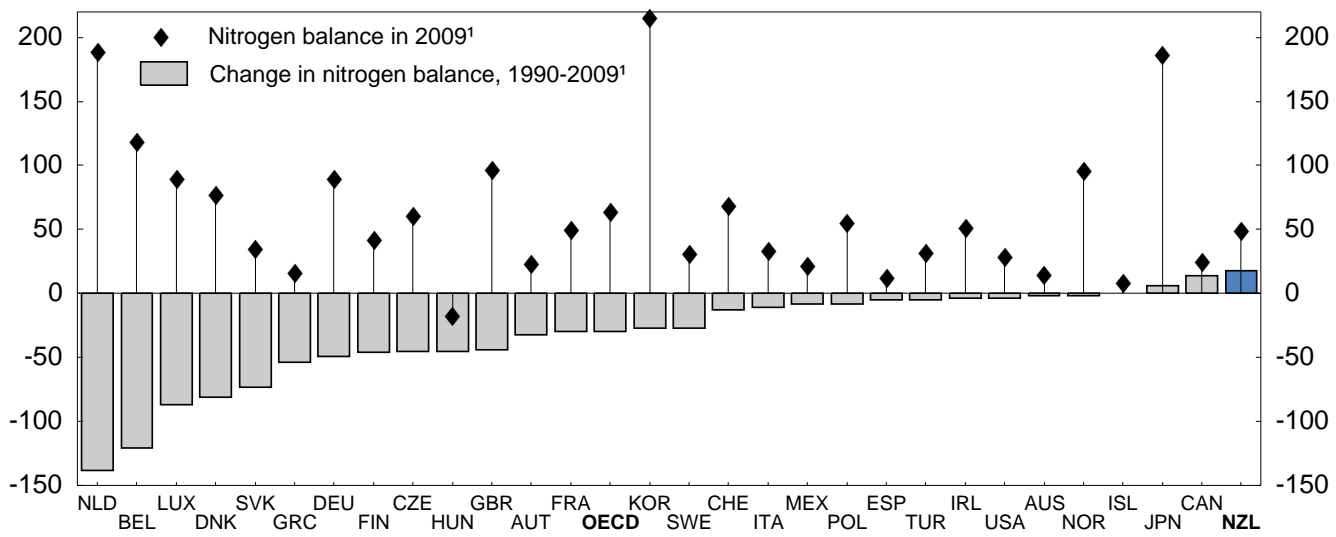

Source: Joint Eurostat/OECD Questionnaire, OECD calculations.

How to read this figure: The gross nitrogen balance is the quantity of nitrogen nutrients entering an agricultural system (mainly from fertilisers and livestock urine) less the quantity taken up by crops and grasslands. A build-up of surplus nutrients in excess of plant needs can lead to nutrient runoff and groundwater pollution, as well as air pollution and greenhouse gas emissions. The change in balance gives an indication of potential environmental pressures from agricultural activities.

\section{Sharing the benefits of resource extraction}

Various studies have revealed vast potential undiscovered mineral reserves in New Zealand, most notably in coal, lignite, ironsand, gold, phosphate and petroleum (Barker, 2008; Christie and Braithwaite, 1999). The extraction of publicly owned, non-renewable assets such as oil, gas and coal represents a temporary economic gain that should be shared with future generations via an appropriate royalty regime. The NZ government collects royalties for petroleum and minerals under the Crown Minerals Act Regime 1991 (Box 4), which is currently being reviewed to ensure royalty rates provide a fair return that properly balances economic, environmental and safety objectives. Combined with the general corporate income tax rate of $28 \%$, the government receives about $42 \%$ of profits generated from oil production (Ministry of Economic Development, 2012). This government take appears low by 
international standards (Figure 26); a review conducted for the State of Israel estimated that the average take among OECD countries with appreciable oil and gas exploration activities was 61-65\% (Hemmings, 2011). These settings made the NZ tax regime the seventh most attractive jurisdiction for oil and gas exploration and production in 2011, according to the Fraser Institute's Global Petroleum Survey (MED, 2012).

\section{Box 4. The royalty and tax regime for fossil fuels}

The royalty regime for publicly owned minerals and petroleum is specified in the Crown Minerals Act Regime 1991. The 2005 Minerals Programme for Petroleum established royalty rates for exploration and mining permit holders as:

- $5 \%$ ad valorem royalty (AVR) on net revenues from petroleum sales (net of transport or storage costs), or

- $20 \%$ accounting profits royalty (APR) from petroleum production revenues net of costs including production and capital costs as well as indirect and decommissioning costs.

Companies with exploration permits are liable to pay only the AVR, whereas those with mining permits and net sales above NZD 1 million must pay the higher of either the AVR or APR in any given period. In 2005, a tax exemption was introduced for non-resident companies engaged in exploratory or development activities on offshore fields. This exemption will remain in effect until 2014 and was intended to offset distortionary effects of the "183-day rule", whereby under some double-tax agreements, non-resident rig or ship operators could be taxed only if they stayed in New Zealand longer than 183 days. This rule created incentives for non-resident operators to leave the country prematurely to avoid the tax liability.

Specific royalty rates are also stipulated for 19 low value-to-weight minerals such as coal, clay, peat and pumice. In addition, gas discoveries made prior to 1986 are subject to the Energy and Resources Levy (ERL) of NZD 0.45 per GJ produced. The ERL is also payable on coal discoveries made after 1977 at a rate of NZD 1.50 per tonne for South Island lignite and NZD 2 per tonne otherwise.

Figure 26. Average government take in oil and gas fiscal regimes

Share of profits captured by the state

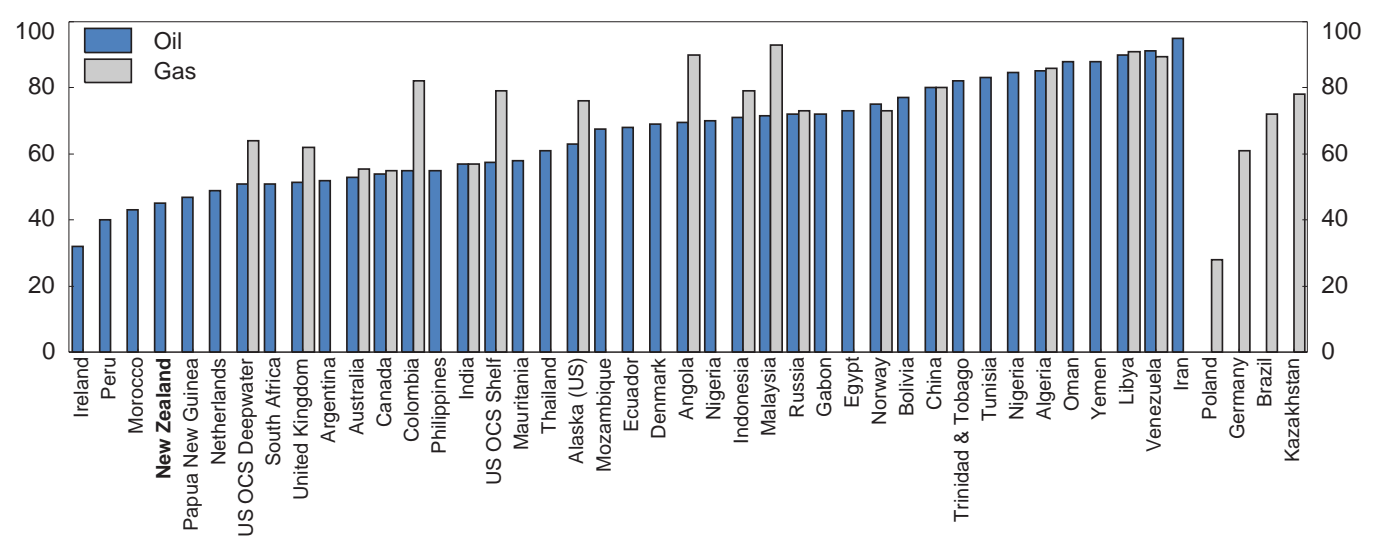

Source: I. Agalliu (2011), "Comparative Assessment of the Federal Oil and Gas Fiscal Systems", U.S. Department of the Interior, Bureau of Ocean Energy Management, Herndon, VA for oil, and D. Johnston (2008), "Changing Fiscal Landscape", Journal of World Energy Law \& Business, Vol. 1, pp. 31-54 for gas.

A government review of the petroleum royalty regime concluded that the current system remains appropriate, given the small size of the industry, high exploration risks and its frontier location 
(MED, 2012). Revenues from royalties are meagre, accounting for only $0.7 \%$ of total government revenues at peak energy prices in 2008. Nonetheless, there may be efficiency gains from removing the revenue-based AVR (Box 4) or moving completely to a rent-based system. Revenue-based royalties are less efficient and regressive because they do not take into account the costs of exploration and may thus discourage investments in new or marginal fields. One approach adopted by countries like Australia and Israel applies a rent tax ( $40 \%$ in the case of Australia) only above a certain threshold rate of return, which has the appeal of better capturing the "pure rent" in excess of profits generated from standard levels of risk, which are taxed at the lower corporate tax rate (OECD, 2011d). However, the NZ government review found that unless prices and discovery increase significantly, moving to a rent tax would probably reduce the government take and could impose costs in terms of administrative complexity. Even so, removing the revenue-based AVR in favour of a pure profit-based royalty system would improve efficiency. The government's concerns that this would eliminate a source of "guaranteed return" should hold little weight: these receipts have never been stable, being driven mainly by volatile energy prices. Moreover, any further expansion of non-renewable resource extraction should be accompanied by clear communication of how royalty revenues will be managed and used. To ensure they provide a long-term benefit to society, resulting proceeds should be used to pay down debt or saved in a sovereign wealth fund, from which only a small share would be withdrawn each year to finance current expenditure needs.

Through the 2009 Petroleum Action Plan, the NZ government explicitly positioned itself as a pro-active partner in expanding petroleum resource development. To encourage oil and gas exploration, it provides a number of tax concessions for expenditures on prospecting and exploration by allowing these to be deducted in the year they are incurred, rather than over the economic lifetime of the well. Once commercial viability is established, these items are clawed back and then deducted over the life of the well. Since 2005, the government has also allowed a tax exemption on income earned from the drilling of both exploratory and development wells offshore by non-resident companies (Box 4). These allowances may be justified to the extent that exploration activities generate knowledge spillovers (comparable to R\&D) that businesses cannot fully appropriate, leading to under-investment in the absence of government support (Mintz and Chen, 2012). Since most of New Zealand's oil is exported, there is potential for such tax provisions to boost export growth. However, the tax benefits create an unwarranted preference for investments in fossil fuel production relative to more sustainable sources of growth. Thus, they are counterproductive to New Zealand's efforts to combat global climate change and should be removed.

\section{Managing water resources}

A growing policy concern in recent years is deteriorating water quality and regional shortages related to the intensification of pastoral farming activity and inefficient allocation among competing uses. As described in Bibbee (2011), the lack of national measurement and standards for water use and quality has been a key problem. In 2009, the Land and Water Forum (which brings together a broad range of stakeholders) produced a series of recommendations and reports around the management of New Zealand's freshwater resources. The government then launched a package of initiatives known as "Fresh Start for Fresh Water", aligning with the Forum's advice. This includes the 2011 National Policy Statement, requiring local governments to set objectives and limits for water quality and use and devise plans to maximise the efficient allocation of fresh water. This new regulatory regime will materially affect all water-intensive land users, including the dairy industry. Financial assistance has also been provided to restore contaminated freshwater bodies and to help develop irrigation infrastructure systems. To enable farmers to monitor their activities' effects on waterways, the government helped fund, develop and provide free access to a widely-used computer-based nutrient-management tool. In March 2013, it released a paper (MfE, 2013) proposing reforms to freshwater management that build on the Land and Water Forum's recommendations. Initiatives that will begin immediately include establishing a National Objectives Framework that sets objectives for ecosystem health and human contact and requires councils to better account for local water use and sources of contaminants. 
A significant amount of research is underway into the development of technologies such as nitrification inhibitors, which slow the release of nitrous oxide - a potent greenhouse gas (GHG) arising from fertiliser use or livestock urine - in soil. However, the use of nitrification inhibitors on less than 5\% of dairy land led to traces of dicyandiamide (DCD) being detected in NZ dairy products. Despite posing no human food safety risk, the resulting media interest highlights a key hurdle the agriculture sector faces to "greening" its growth. Concerns over the presence of DCD in milk arise from the lack of international standards on acceptable levels in food from its use on pasture land.

The highly successful cap-and-trade system for nitrogen discharge allowances at Lake Taupo may serve as a model for other regions to design efficient mechanisms to achieve water-quality targets where conditions are appropriate. However, such schemes involve substantial upfront costs and leverage the long-run incentives provided by the NZ Emissions Trading System (ETS) (Bibbee, 2011), underlining the importance for the government to stand firm on its commitment to continue the scheme.

\section{Strengthening climate protection}

The NZ ETS has been the main instrument for charging GHG emitters for the environmental costs of their activities since its introduction in 2008. While a commendable step forward, ETS price signals remain weak because of temporary provisions, including a price cap on emission units and free permit allocations to vulnerable sectors. Recently passed legislation enables the government to begin capping and auctioning domestic allocations, which would help strengthen price signals. However, New Zealand's ability to reduce emissions intensity is limited by its relatively high proportion of agricultural methane and nitrous oxide emissions (Figure 27) (Bibbee, 2011). Farming has been left out of the ETS pending the development of viable abatement technologies. Following the sharp increase in global dairy prices, the rapid expansion of the dairy sector over the 2000s and the associated fertiliser use helped drive nitrous oxide emissions to about 25\% above 1990 levels by 2010. Meanwhile, total methane emissions increased only 4\% between 1990 and 2010, placing New Zealand as a world leader in cutting methane emissions per dairy cow. This gives the country a strong comparative advantage in developing cost-effective technologies to reduce agricultural emissions. The government is investing substantially in R\&D in this area through the Primary Growth Partnership initiative, Change Research grants and through its active role in the Global Research Alliance on Agricultural Greenhouse Gases.

Figure 27. New Zealand's emissions by sector in 1990 and 2010

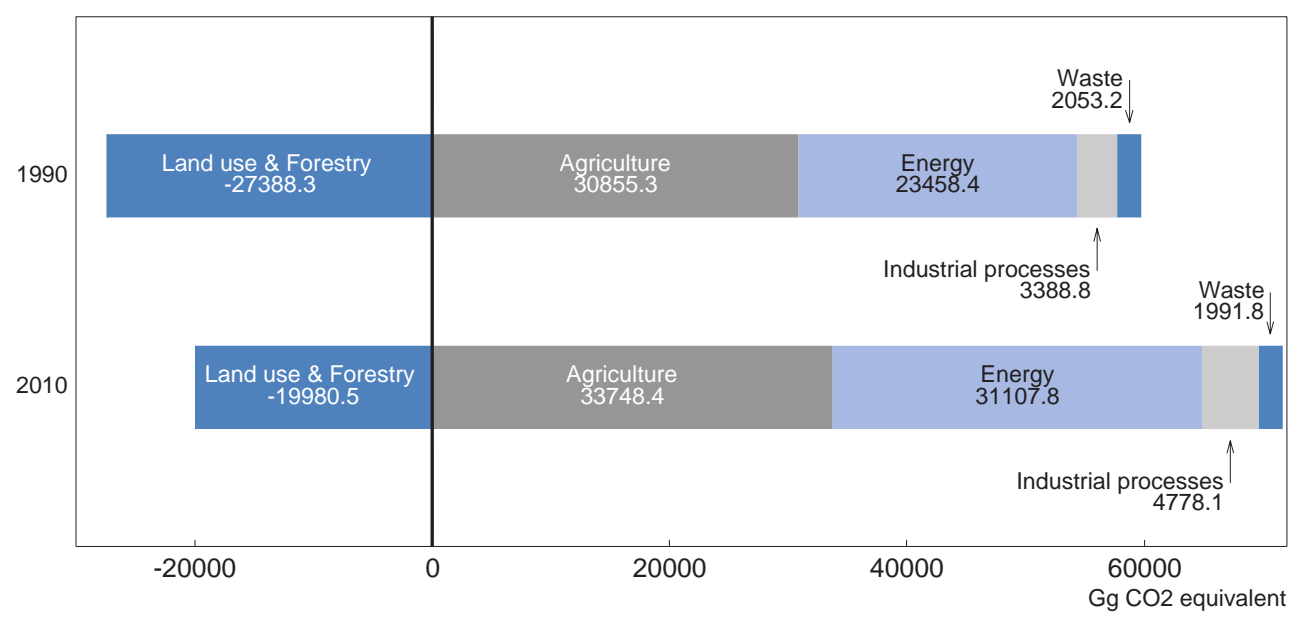

Source: Ministry for Environment, New Zealand's Greenhouse Gas Inventory 1990-2010. 
Meanwhile, the energy sector has been the main source of growth in GHG emissions since 1990 (Figure 27), reflecting to a large extent rising motor vehicle use and an old car fleet (Bibbee, 2011). Although the government has implemented regulations to encourage fleet renewal, prices for automotive fuels and tax rates on gasoline and diesel are very low by international standards (Figure 28). The government began a series of petrol tax hikes in July 2012 that will amount to NZD 0.15 per litre (USD 0.125) over three years, mainly to fund infrastructure, but tax rates will remain lower than in most other OECD countries. More generally, the revenues collected from environmentally-related taxes are also relatively low, both as a share of GDP and of total government revenues. However, there are preliminary signs that the NZ ETS has influenced diesel and petrol prices somewhat and provoked a reduction in deforestation (Covec, 2011).

Figure 28. Fuel taxes

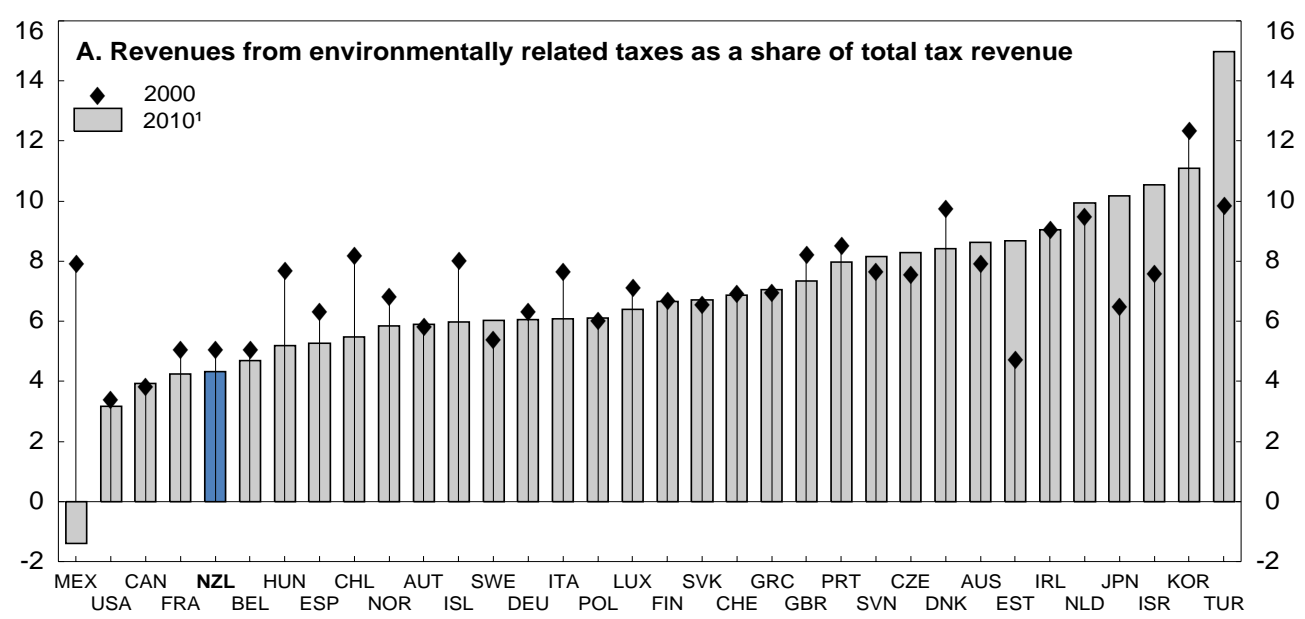

B. Tax on gasoline ${ }^{2}$ (USD per litre), 2012 q3 1

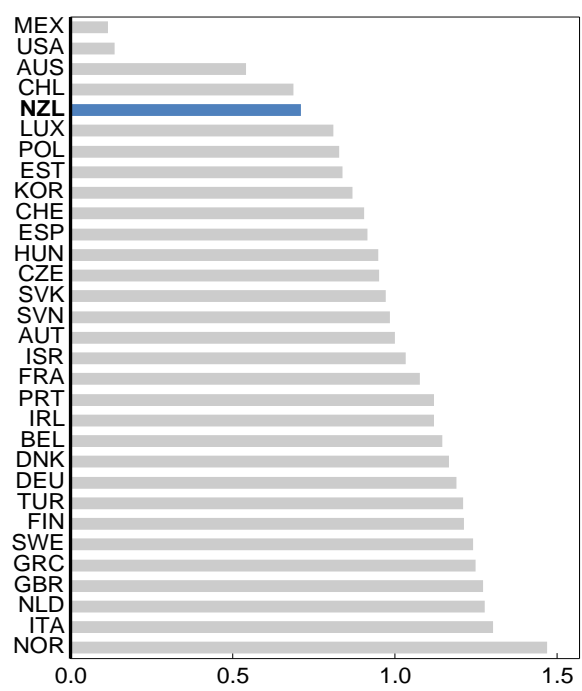

C. Diesel tax as per cent of gasoline tax, 2012 q3 ${ }^{1}$

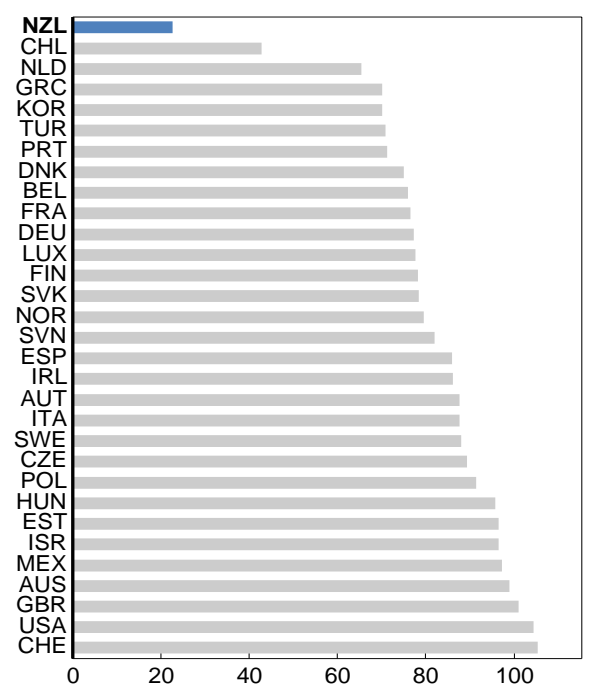

1. Or latest available year.

2. Unleaded premium $95 \mathrm{RON}$; taxes comprise both excises and VAT.

Source: OECD, Energy database and OECD, EEA database. 


\section{Box 5. Policy recommendations to support sustainable long term growth}

\section{Boosting international linkages}

- To promote a high-performance ICT infrastructure, clarify the competition policy framework for the broadband market, and adjust regulations to ensure consistent pricing strategies of copper and fibre networks.

- $\quad$ Review air service agreements to ensure capacity limits are not restricting trade growth, especially with Asian countries where limits have been reached.

- $\quad$ Pass the Commerce (Cartels and Other Matters) Amendment Bill to strengthen competition in international transport by eliminating ratemaking agreements exemptions from the Commerce Act.

- Improve the transparency of the FDI screening regime.

\section{Strengthening innovation and human capital contribution}

- To address equity financing gaps, shift the allocation of the NZ Venture Investment Fund to provide greater support for early-expansion stage firms. Clarify the tax treatment of venture capital investments. To encourage equity market development, change the investment strategy of KiwiSaver default funds to a life-cycle approach.

- To improve the conditions for intangible asset investments, adjust tax treatment of patent sales to be consistent with that of other assets. Consider allowing accelerated depreciation of patent assets. Redesign the Technology Development Grants to simplify the approval criteria and ensure access to small, innovative start-ups, and continue to monitor its effectiveness.

- Consider boosting practical training components within engineering degrees through support for student internship opportunities, especially with tertiary education institutions located near engineering clusters.

- Collaborate with Australian tax authorities to enforce the same repayment obligations on NZ student debt-holders working there as those who remain at home.

\section{Reducing macroeconomic imbalances and the effects of ageing}

- Link the age of pension eligibility with life expectancy to encourage older workers' labour force participation.

- To mitigate external vulnerabilities and ageing-related cost pressures, raise public saving by permanently targeting a low net public debt ratio.

\section{Managing natural capital and climate change}

- In the petroleum sector, remove the preferential tax treatment for exploration expenditures and the income tax exemption on offshore oil and gas activities for non-resident companies. Eliminate the revenue-based royalties and move to a pure profit-based regime; if significant discoveries are made, switch to a rent-based system. To ensure that proceeds are shared with future generations, clearly designate them for debt repayment or, if significant discoveries are made, for sovereign wealth fund contributions.

- $\quad$ Strengthen price signals within the ETS by phasing out transition provisions. In the meantime cap and auction domestic allocations.

- Continue to encourage the development of market-based mechanisms where possible to manage the supply and quality of fresh water. 


\section{Bibliography}

Anderson, K. (2008), "Fifty Years of Distortions in World Agricultural Markets," Joint MFAT/MAF/Treasury Guest Lecture, Wellington, 27 March 2008, www.treasury.govt.nz/publications/media-speeches/guestlectures/pdfs/pgls-anderson-slides.pdf.

André, J-P. (2011), “Economic Imbalances: New Zealand's Structural Challenge”. New Zealand Treasury Working Paper 11/03.

Barker, R. (2008), "The Natural Resource Potential of New Zealand", http://www.minerals.co.nz/pdf/Natural_Resource_NZ_web.pdf

Barnes, S., R. Bouis, P. Briard, S. Dougherty and M. Eris (2011), “The GDP Impact of Reform: A Simple Simulation Framework", OECD Economics Department Working Papers, No. 834, OECD Publishing.

Battersby, B. and R. Ewing (2005), "International Trade Performance: the Gravity of Australia's Remoteness", Australian Treasury Working Paper, 2005-03.

Bell, M. (2012), “Fiscal Sustainability Under an Ageing Population Structure”, Draft Paper for the Long-Term Fiscal External Panel, August.

Bibbee, A. (2011), "Green Growth and Climate Change Policies in New Zealand", OECD Economics Department Working Papers, No. 893, OECD Publishing.

Bibbee, A. (2013), "Improving School-to-work Transitions in New Zealand", OECD Economics Department Working Papers, forthcoming.

Blanchard, O. (2007), “Current Account Deficits in Rich Countries”, IMF Staff Papers 54(2), 191-219.

Bloom, N., C. Genakos, R. Sadun and J. van Reenen (2011), "Management Practices Across Firms and Countries", Harvard Business School Working Paper, No. 12-052, December.

Bouis, R., R. Duval and F. Murtin (2011), "The Policy and Institutional Drivers of Economic Growth Across OECD and Non-OECD Economies: New Evidence from Growth Regressions", OECD Economics Department Working Papers, No. 843, OECD Publishing.

Boulhol, H. and A. de Serres (2008), "Have Developed Countries Escaped the Curse of Distance?", OECD Economics Department Working Papers, No. 602, OECD Publishing.

Bourlès, R., G. Cette, J. Lopez, J. Mairesse and G. Nicoletti (2010), "Do Product Market Regulations in Upstream Sectors Curb Productivity Growth?: Panel Data Evidence for OECD Countries", OECD Economics Department Working Papers, No. 791, OECD Publishing.

Brandt, N., P. Schreyer and V. Zipperer (2013), “A Green Productivity Measure: With Special Results for New Zealand”, Technical Background Paper, ECO/EDR(2013)/ANN2.

Burnside, C. (2011), "New Zealand's Risk Premium and Its Role in Macroeconomic Imbalances”, Paper prepared for Policy Forum: New Zealand's Macroeconomic Imbalances - Causes and Remedies, Wellington. 


\section{ECO/WKP(2013)68}

Cecchetti, S.G., M.S. Mohanty and F Zampolli (2011), “The Real Effects of Debt,” Bankfor International Settlements Working Papers, No. 352.

Christie, A. and R. Braithwaite (1999), "The Mineral Potential of NZ", Wellington: Institute of Geological and Nuclear Sciences.

Commerce Commission (2012), "Unbundled Bitstream Access Service Price Review”, 3 December.

Comin, D., M. Dmitriev, E. Rossi-Hansberg (2012), "The Spatial Diffusion of Technology”, CEPR Discussion Papers, No. 9208.

Covec (2011), "Impacts of the NZ ETS: Actual vs. Expected Effects", Final Report Prepared for the Ministry for the Environment, April.

Crawford, R., R. Fabling, A. Grimes and N. Bonner (2007), "National R\&D and Patenting: Is New Zealand an Outlier?" New Zealand Economic Papers, Vol. 41, No. 1.

Cross, B. (2003), "Bulk Funding in New Zealand: A Retrospective", Education International Working Papers, No. 8, September.

De Michelis, A., M. Estevao, and B.A.Wilson (2013), "Productivity or Employment : Is it a Choice?" IMF Working Paper 13/97.

Department of Labour (2008), "Engineers in the New Zealand Labour Market”, Department of Labour Report, Wellington.

Dimaranan, B., E. Ianchovichina, and W.J. Martin (2007), "China, India, and the future of the world economy: fierce competition or shared growth?”, Policy Research Working Paper Series 4304, World Bank.

Dolman, B., D. Parham and S. Zheng (2007), “Can Australia Match US Productivity Performance?", Australian Government Productivity Commission, Staff Working Paper, March.

Dumont, J-C. and G. Lemaitre (2005), "Counting Immigrants and Expatriates in OECD Countries: A New Perspective", OECD Social, Employment and Migration Working Papers, No. 25, OECD Publishing.

Égert, B. (2010), "Fiscal Policy Reaction to the Cycle in the OECD: Pro- or Counter-Cyclical?",OECD Economics Department Working Papers, No. 763, OECD Publishing.

Ericsson, N.R. and J. G. MacKinnon (2002), "Distributions of Error Correction Tests for Cointegration", Econometrics Journal, 5(2), 285-318.

Ernst and Young (2012), Looking Beyond the Obvious: Globalisation and New Opportunities for Growth.

Fabling, R. and L. Sanderson (2011), "Foreign Acquisition and the Performance of New Zealand firms", Reserve Bank of New Zealand Discussion Paper Series, DP2011/08, Reserve Bank of New Zealand.

Gallup, J.L. and J. Sachs (1999), "Geography and Economic Development”, in B. Pleskovic and J.E. Stiglitz (eds.), Annnual World Bank Conference on Development Economics, 1998, World Bank, Washington, DC. 
Gonzales, F., J.B. Jensen, Y. Kim and H. Nordäs (2012), "Globalisation of Services and Jobs", Policy Priorities for International Trade and Jobs, Chapter 5, OECD Publishing.

Gorman, E., G.M. Scobie and A. Towers (2012), "Health and Retirement of Older New Zealanders", NZ Treasury Working Paper, No. 12/02.

Guillemette, Y. (2009), "Structural Policies to Overcome Geographic Barriers and Create Prosperity in New Zealand," OECD Economics Department Working Papers, No. 696, OECD Publishing.

Harrigan, J. (2010), “Airplanes and Comparative Advantage”, Journal of International Economics, Vol. 82, 181-194.

Heatley, D. and B. Howell (2010), "Submission on: Regulatory Implications of Structural Separation", Prepared in response to the Ministry of Economic Development discussion document Regulatory Implications of Structural Separation, October.

Hodgson, R. and J. Poot (2010), "New Zealand Research on the Economic Impacts of Immigration 2005-2010: Synthesis and Research Agenda", Economic Impacts of Immigration Working Paper Series, IMSED Research, Department of Labour.

Howell, B. (2012), "Competition and regulation policy in Antipodean Government-funded UltraFast Fibre Broadband Markets", New Zealand Institute for the Study of Competition and Regulation, August.

Hurnard, R. (2005), "The effect of New Zealand Superannuation Eligibility Age on the Labour Force Participation of Older People", New Zealand Treasury Working Paper, No. 05/09.

Hummels, D. (2009), "Globalisation and Freight Transport Costs in Maritime Shipping and Aviation", International Transport Forum, Forum Papers, No. 2009-03.

Hummels, D. and G. Schaur (2012), “Time as a Trade Barrier”, NBER Working Paper, No. 17758.

IPENZ (2010), “The demand for and supply of engineers", Report for the National Engineering Education Plan, Institution of Professional Engineers New Zealand.

Johansson, A., Y. Guillemette, F. Murtin, D. Turner, G. Nicoletti, C. de la Maisonneuve, G. Bousquet, and F. Spinelli (2013), "Long-Term Growth Scenarios", OECD Economics Department Working Papers, No. 1000, OECD Publishing.

Kandilov, I.T. and T. Grennes (2012), "The Determinants of Service Offshoring: Does Distance Matter?", Japan and the World Economy, Vol. 24, 36-43.

Kaye Blake, W., C.M. Saunders and M. Emanuelsson (2006), "Current Contribution of Four Biotechnologies to New Zealand's Primary Sector", 2006 Annual Meeting, 12-18 August, Queensland, Australia, International Association of Agricultural Economists.

Khwaja, M. and B. Boddington (2009), "Too Early to Retire? Growing participation of older New Zealanders in the Labour Force", New Zealand Population Review, Vol. 35, 75-93.

Labuschagne, N. And P. Vowles (2010), "Why are Real Interest Rates in New Zealand so High? Evidence and Drivers", New Zealand Treasury Working Paper, No. 10/09. 
Lane, P. (2011), "External Imbalances and Macroeconomic Policy in New Zealand”, Paper prepared for Policy Forum: New Zealand's Macroeconomic Imbalances - Causes and Remedies, Wellington.

Lane, P. and G. Milesi-Ferretti (2002), "Long-Term Capital Movements", NBER Macroeconomics Annual 2002, Cambridge, MA: The MIT Press.

Lane, P. and G. Milesi-Ferretti (2007), "The External Wealth of Nations Mark II: Revised and Extended Estimates of Foreign Assets and Liabilities, 1970-2004", Journal of International Economics, Vol. 73, 223-250, November.

Law, D., M. Genc and J. Bryant (2009), "Trade, Diaspora and Migration to New Zealand", NZIER Working Paper, 2009/4, New Zealand Institute for Economic Research.

Lerner, J., D. Moore and S. Shepherd (2005), “A Study of New Zealand's Venture Capital Market and Implications for Public Policy", Report submitted to the Ministry of Research, Science \& Technology, September.

McCann, P. (2009), "Economic Geography, Globalisation and New Zealand's Productivity Paradox", New Zealand Economic Papers, Vol. 43, No. 3.

MBIE (2012), "Review of KiwiSaver Default Provider Arrangements", Ministry of Business, Innovation \& Employment Discussion Document, November.

MED (2011), "Evaluation of NZTE Investment Support Activities", Ministry of Economic Development, August.

MED (2012), "Review of the Royalty Regime for Petroleum”, Ministry of Economic Development, March.

MfE (2013), "Freshwater Reform 2013 and Beyond”, Ministry for the Environment, Wellington, March.

Ministry of Education (2008), "The New Zealand Education System: An Overview”, Wellington.

Mintz, J. and D. Chen (2012), "Capturing Economic Rents from Resources Through Royalties and Taxes", University of Calgary School of Public Policy Research Papers, Vol. 5, No. 30, October.

Miroudot, S. and K. de Backer (2012), “Mapping Global Value Chains”, Policy Dialogue on Aid for Trade, OECD Publishing.

Morphis, E. (2009), "The Shift to School Choice in New Zealand", National Center for the Study of Privatization in Education, Teachers College, Columbia University, Research Publications 179.

New Zealand Government (2011), Economic Development Indicators 2011.

New Zealand Productivity Commission (2012), "International Freight Transport Services Inquiry: Final Report", April.

New Zealand Treasury (2009a), "Challenges and Choices: New Zealand's Long-Term Fiscal Statement", October 2009.

New Zealand Treasury (2009b), "International Connections and Productivity: Making Globalisation Work for New Zealand", New Zealand Treasury Productivity Paper, No. 09/01. 
New Zealand Treasury (2010), "Will Higher National Saving Lead to Higher GDP Growth or Income Levels in New Zealand?", Background paper submitted to Savings Working Group.

Nordäs, H. (2008a), "The Impact of Services Trade Liberalisation on Trade in Non-Agricultural Products", OECD Trade Policy Working Paper, No. 81, OECD Publishing.

Nordäs, H. (2008b), "Trade and Regulation: Computer Services and Other Business Services", Paper prepared for Services Experts Meeting in Business Services, Paris, 24 June.

NZBio (2010), 2010 Bioscience Industry Report.

NZIER (2011), "Industry Productivity and the Australia-New Zealand income gap", NZIER public discussion document, September.

OECD (2007a), OECD Economic Survey of New Zealand 2007, OECD Publishing.

OECD (2007b), OECD Reviews of Innovation Policy: New Zealand, OECD Publishing.

OECD (2009), OECD Science, Technology and Industry Scoreboard 2009, OECD Publishing.

OECD (2011a), OECD Communications Outlook 2011, OECD Publishing.

OECD (2011b), OECD Science, Technology and Industry Scoreboard 2011, OECD Publishing.

OECD (2011c), OECD Economic Survey of New Zealand 2011, OECD Publishing.

OECD (2011d), OECD Economic Survey of Israel 2011, OECD Publishing.

OECD (2012), Starting Strong III: A Quality Toolbox for Early Childhood Education and Care, OECD Publishing.

OECD (2012a), OECD Science, Technology and Industry Outlook 2012, OECD Publishing.

OECD (2012b), OECD Education at a Glance 2012, OECD Publishing.

OECD (2012c), OECD Economic Policy Reforms 2012: Going for Growth, OECD Publishing.

OECD (2012d), Settling in: OECD Indicators of Immigrant Integration 2012, OECD Publishing.

OECD (2013), Education Policy Outlook: New Zealand, OECD Publishing, forthcoming.

OECD (2013a), Interconnected Economies: Benefiting from Global Value Chains, OECD Publishing, forthcoming.

OECD (2013b), OECD Communications Outlook, forthcoming.

OECD (2013c), OECD Economic Survey of Switzerland 2013, forthcoming, OECD Publishing.

Papadopoulos, T. (2012), "Who Left, Who Returned and Who was Still Away?: Migration patterns of 2003 graduates, 2004-2010", Labour and Immigration Research Centre, Ministry of Business, Innovation and Employment, September 2012. 
Palazzi, P. (2011), “Taxation and Innovation”, OECD Taxation Working Papers, No. 9.

Plantier, L.C. (2003), "New Zealand's Macroeconomic Reforms after 1984 and the Neutral Rate of Interest", Paper presented at the Reserve Bank of New Zealand workshop "Analysing the Economy for Monetary Policy Purposes: Key Issues", Wellington.

Procter, R. (2011), "Enhancing Productivity: Towards an Updated Action Agenda", Ministry of Economic Development, Occasional Paper, No. 11/01.

Rauch, J. (1999), "Networks versus Markets in International Trade", Journal of International Economics, Vol. 48, 7-35.

Rauch, J. and V. Trindade (2002), "Ethnic Chinese Networks in International Trade", Review of Economics and Statistics, Vol. 84, 116-130.

Reddell, M. (2013), "The Long-Term Level "Misalignment” of the Exchange Rate: Some Perspectives on Causes and Consequences", Paper prepared for the Reserve Bank/Treasury Exchange Rate Forum, Wellington, 26 March.

RBNZ (2007), "Productivity, Investment, Exports and Monetary Policy", Background paper for Finance and Expenditure Select Committee Inquiry into the Future Monetary Policy Framework.

Rodrik, D. (2000), “Saving Transitions”, World Bank Economic Review, Vol. 14, No. 3, 481-507.

Rose, D. (2010), “The influence of Foreign Assets and Liabilities on Real Interest Rates", Institute of Policy Studies Working Paper, No. 10/09, June.

Skilling, D. and D. Boven (2007), "So Far Yet So Close: Connecting New Zealand to the Global Economy", New Zealand Institute Discussion Paper, 2007/1.

Smith, K. (2006), "Public Policy Framework for the New Zealand Innovation System", Ministry of Economic Development Occasional Paper, 06/06.

Smyth, R. and C. Lane (2009), Skills and Education: How Well Do Educational Qualifications Measure Skills?, Ministry of Education, Wellington, August.

Springford, L. (2006), “Tomorrow's Primary Schools: Time to Evaluate Governance Alternatives”, Policy Quarterly, Vol. 2, No. 3.

Stillman, S. and M. Velamuri (2010), "Immigrant Selection and the Returns to Human Capital in New Zealand and Australia", IMSED Research, Department of Labour.

Stillman, S. and D.C. Maré (2009), "The Labour Market Adjustment of Immigrants in New Zealand", Working Paper Commissioned by the Economic Impacts of Immigration research programme of the Department of Labour.

Sweet, A. and M. Nash (2007), "Firms' Decisions on the Location of Economic Activity - a Survey", Report Prepared for the New Zealand Treasury.

TEC (2012), Tertiary Education Strategy 2010-15, Ministry of Education, December, Wellington. 
Warda, J. (2006), “Tax Treatment of Business Investments in Intellectual Assets: An International Comparison”, OECD STI Working Paper, No. 2006/4, OECD Publishing.

Woodward Partners (2011), "Valuation of the Crown's Royalty Streams from the Petroleum Estate", Prepared for the Ministry of Economic Development, March.

WTO (2008), World Trade Report 2008.

Wylie, C. (2012), Vital Connections: Why We Need More Than Self-Managing Schools, NZCER Press, Wellington.

Zuccollo, J., S. Maani, B. Kaye-Blake, and L. Zheng (2013), "Private Returns to Tertiary Education: How Does New Zealand Compare?", New Zealand Treasury Working Paper, forthcoming. 


\title{
Annex 1
}

\section{Estimating the relationship between net foreign assets and interest rates}

\begin{abstract}
A large stock of net external debt may drive up the domestic real interest rate relative to foreign rates through a number of channels. One is that the accumulation of external deficits represents a wealth transfer to foreign residents, which may lower both future domestic income and money demand. The resulting expectation of future real exchange rate depreciation necessary to pay back that debt requires domestic real interest rates to rise above foreign rates to satisfy the so-called covered interest parity condition. Furthermore, if domestic and foreign bonds are imperfect substitutes, there is a portfolio-balance effect whereby the higher demand for assets denominated in foreign currency generates a domestic risk premium. In addition, higher net foreign debt levels may be associated with increased rollover risk and default risk, which may add to the risk premium.
\end{abstract}

Indeed, the level of net foreign assets appears to be negatively correlated to real interest rates across OECD countries (Figure A1.1). Empirical analysis also provides evidence that countries with large net foreign liabilities tend to have significantly higher real interest rates (Rose, 2010; Lane and Miles-Ferretti, 2002). However, Plantier (2003) finds that the stock of government debt plays a more important role in driving interest-rate premiums, whereas Egert (2010) finds that risk premiums arise only for very high public debt levels. Rose (2010) further finds that small countries pay an additional premium, perhaps due to their lower ability to spread risk compared to larger economies.

To estimate the relationship between net external debt levels and interest rates, a panel cointegration approach is used based on Lane and Milesi-Ferretti (2002) and Rose (2010). In the light of unit root test results that for most countries could not reject the null hypothesis of non-stationarity in the main interest rate and net foreign asset series, the following error-correction model representation was assumed:

$$
\Delta I R L R_{i t}=\beta^{\prime} \Delta Z_{i t}+\eta \Delta I R L R_{i t-1}-\lambda\left(I R L R_{i t-1}-\gamma^{\prime} Z_{i t-1}\right)+\varepsilon_{i, t}, \quad Z_{i t}=\left[N F A_{i t}, P D E B T_{i t}, R E E R_{i t}\right]
$$

where for each country $i$, the dependent variable $I R L R$ is the interest rate on 10 -year government bonds (deflated by lagged changes in the GDP deflator). Estimations were also performed replacing the dependent variable with the long-term real interest rate differential vis-à-vis the United States (IRLRDIFF). Co-integrating relationships were tested between IRLRL and the various variables in the vector $Z$, including the level of net foreign assets as a share of GDP (NFA), gross public debt as a share of GDP (PDEBT) and measures of the real exchange rate, both in effective terms $(R E E R)$ as well as in dollar terms $(R E R)$. The one-period-ahead change in the real exchange rate is used to proxy future expectations. Variables for short-term real interest rates (IRSR) and their differential versus the United States (IRSRDIFF) are also included. 
Figure A1.1. Real long-term interest rates and net foreign assets

Mean 1990-07

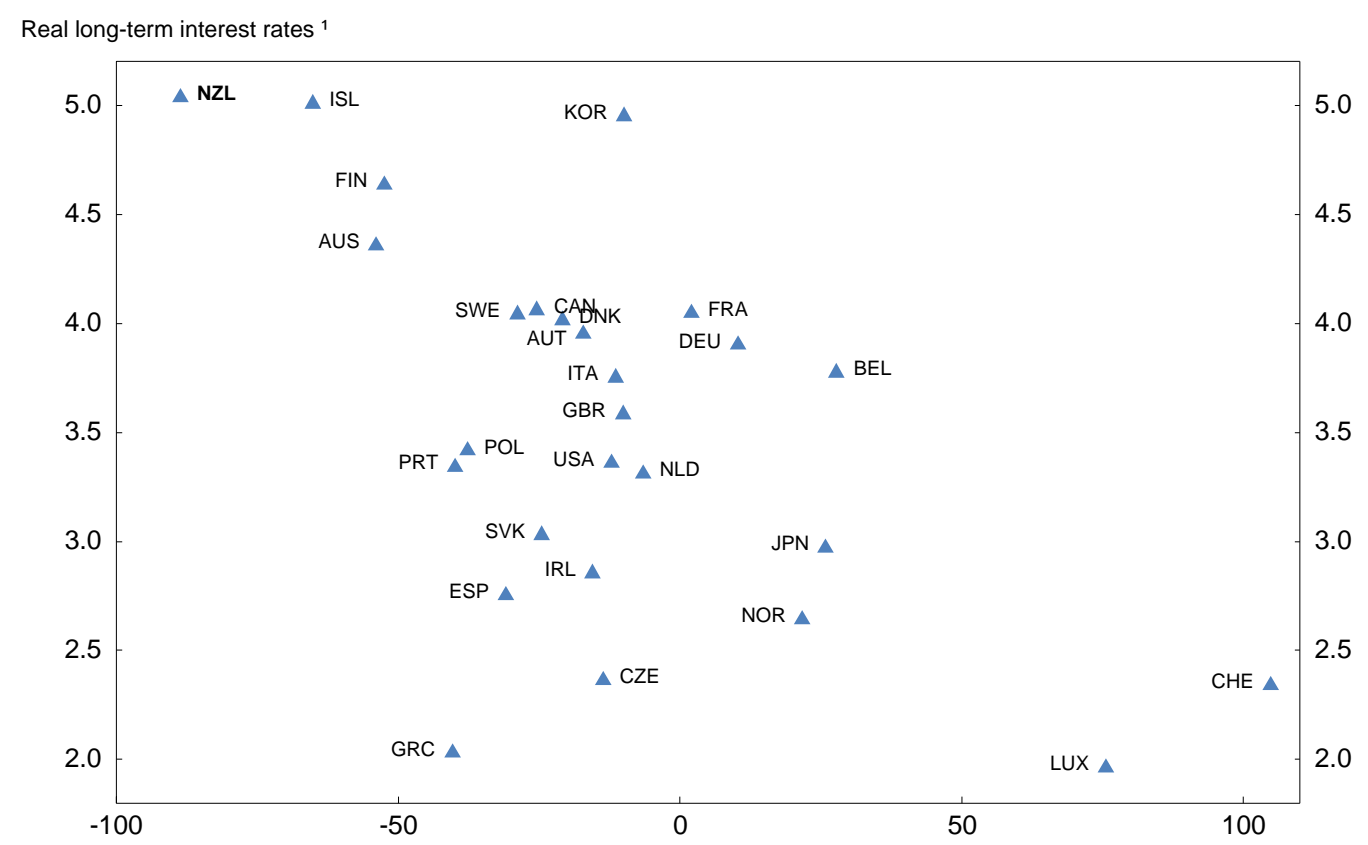

1. Interest rate on 10 -year government bonds, deflated by lagged changes in the GDP deflator.

Source: Lane and Milesi-Feretti (2007) and OECD Economic Outlook 92 database.

Net foreign asset data is taken from the External Wealth of Nations II dataset constructed by Lane and Milesi-Ferretti (2007). Panel regressions are estimated on annual data for a sample of 25 OECD countries over the 1970-2007 period so as to exclude the extraordinary effects of the financial crisis. During this period, external positions ranged from the extremes of net foreign asset stocks of 169\% of GDP (held by Luxembourg in 1990) to net external liabilities of 165\% of GDP (Finland in 1999). Time period fixed effects are included to account for the influence of a time-varying world real interest rate.

The results support a significant long-run negative relationship between long-term real interest rate levels and net foreign asset holdings, based on a highly significant error-correction adjustment parameter, as shown in the first column of Table A1.1. The estimated impact is fairly small: a 10 percentage point increase in net foreign debt as a share of GDP is associated with a 13 basis point increase in long-term real interest rates. These estimates are of similar magnitude to those found by Rose (2010). They imply that long-term rates in New Zealand are over 1 percentage point higher than they would be with zero net foreign assets. While gross government debt levels are not found to be significant when included in the co-integrating equation, their fluctuations do positively influence interest rate changes significantly in the short run. That no long-term impact on real interest rates was found from public debt levels may reflect some multicollinearity between PDEBT and NFA: where Ricardian offsets are incomplete, higher public debt levels may lead to a deterioration in the external position. However, the government debt variable was still insignificant when $N F A$ was excluded from the co-integrating equation. The exchange rate variable was also found to be insignificant in both the long run and short run. Changes in short-term real interest rates $(I R S R)$ are found to significantly influence the short-run dynamics of long-term rates. 
Table A1.1. Results from panel regressions on real long-term interest rates

\begin{tabular}{|c|c|c|c|}
\hline & [1] & [2] & [3] \\
\hline $\begin{array}{l}\text { Dependent variable } \\
\text { found. }\end{array}$ & $\triangle I R L R$ & $\Delta I R L R$ & $\Delta I R L R D I F F$ \\
\hline Constant & $\begin{array}{c}1.00^{\star * *} \\
(0.18)\end{array}$ & $\begin{array}{l}1.02^{* * *} \\
(0.18)\end{array}$ & $\begin{array}{c}-0.111^{* *} \\
(0.05)\end{array}$ \\
\hline \multicolumn{4}{|l|}{ Long-run } \\
\hline$N F A_{t-1}$ & $\begin{array}{c}-0.013^{\star * *} \\
(0.00)\end{array}$ & $\begin{array}{c}-0.014^{* * *} \\
(0.00)\end{array}$ & $\begin{array}{c}-0.014^{\star * *} \\
(0.00)\end{array}$ \\
\hline $\begin{array}{l}\text { ECM adjustment parameter } \\
\text { (t-stat) }\end{array}$ & $\begin{array}{c}-0.30^{* * *} \\
(5.57)\end{array}$ & $\begin{array}{c}-0.30^{\star * *} \\
(5.53)\end{array}$ & $\begin{array}{c}-0.257^{* * *} \\
(5.55)\end{array}$ \\
\hline$\Delta R E E R_{t+1}$ & $\begin{array}{l}-0.001 \\
(0.01)\end{array}$ & $\begin{array}{l}-0.002 \\
(0.01)\end{array}$ & \\
\hline$\Delta R E R_{t+1}$ & & & $\begin{array}{l}0.009 \\
(0.01)\end{array}$ \\
\hline$\triangle P D E B T_{t}$ & $\begin{array}{c}0.029^{* *} \\
(0.01)\end{array}$ & $\begin{array}{c}0.053^{* *} \\
(0.02)\end{array}$ & $\begin{array}{l}0.010 \\
(0.01)\end{array}$ \\
\hline$\triangle P D E B T_{t}(>75 \%)$ & & $\begin{array}{l}-0.058^{*} \\
(0.03)\end{array}$ & \\
\hline$\triangle P D E B T_{t}(>125 \%)$ & & $\begin{array}{l}-0.065 \\
(0.04)\end{array}$ & \\
\hline$\Delta \mathrm{IRLR}_{t-1}$ & $\begin{array}{c}0.175^{* * *} \\
(0.03)\end{array}$ & $\begin{array}{c}0.175^{\star * *} \\
(0.03)\end{array}$ & \\
\hline$\Delta \mathrm{IRSR}_{t}$ & $\begin{array}{l}0.256^{* * *} \\
(0.02)\end{array}$ & $\begin{array}{l}0.256^{\star * *} \\
(0.02)\end{array}$ & \\
\hline$\Delta \mathrm{IRLRDIFF}_{t-1}$ & & & $\begin{array}{c}0.163^{\star *} \\
(0.07)\end{array}$ \\
\hline$\Delta$ IRSRDIFF $_{t-1}$ & & & $\begin{array}{l}0.181^{* * *} \\
(0.02)\end{array}$ \\
\hline Adjusted- $\mathrm{R}^{2}$ & 0.438 & 0.444 & 0.245 \\
\hline S.E.E. & 1.102 & 1.097 & 1.301 \\
\hline Number of obs. & 616 & 616 & 613 \\
\hline Fixed time effects & Yes & Yes & No \\
\hline
\end{tabular}

1. Robust standard errors in parentheses unless otherwise noted. * , **, and *** signify statistical

significance at $10 \%, 5 \%$, and $1 \%$, respectively.

2. Ericsson and Mackinnon (2002) critical values used to determine significance.

Source: OECD calculations.

Non-linear effects on interest rates were tested for at high levels of government debt, in particular for values of $P D E B T$ above $75 \%$ and above $125 \%$, which are the thresholds at which fiscal risk premiums are imposed in the OECD long-term projection model (see Box 1). These effects, shown in column two, were found to be insignificant or of the wrong sign. Threshold effects are similarly tested for absolute levels of NFA above $50 \%$ at successive increments of $10 \%$. However, such effects were found to be statistically insignificant or not of the expected sign and are thus not displayed.

The third column of Table A1.1 shows the results for estimations on the long-run real interest rate differential versus the United States. In this equation, bilateral exchange rates are used $(R E R)$, measured in 
units of domestic currency per US dollar, deflated by changes in private consumption deflators. Changes in the lag of the short-term real interest rate differential (IRSRDIFF) are also included in the short run. Co-integration with net foreign asset levels remains well supported in this specification, with a 10 percentage point of GDP increase in net foreign debt associated with a 14 basis point widening in the real interest rate differential with the United States. Gross public debt levels are no longer significant in this specification. Time fixed effects are removed in the reported results, assuming that the United States acts effectively as a world real interest rate, but keeping them in the estimation does not change the results significantly. The results in either column do not change significantly when controlling for the potential correlation of residuals over time or contemporaneously across cross-sections. 
ECO/WKP(2013)68

\section{WORKING PAPERS}

The full series of Economics Department Working Papers can be consulted at www.oecd.org/eco/workingpapers/

1075. Do structural policies affect macroeconomic stability?

(July 2013) by Volker Ziemann

1074. A simple fiscal stress testing model - case studies of Austrian, Czech and German economies (July 2013) by Ondra Kamenik, Zdenek Tuma, David Vavra and Zuzana Smidova

1073. Road connectivity and the border effect: evidence from Europe (July 2013) by Henrik Braconier and Mauro Pisu

1072. Fiscal consolidation across government levels. Part 3: Intergovernmental grants, pro- or counter-cyclical?

(July 2013) by Hansjörg Blöchliger and Balázs Égert

1071. Fiscal consolidation across government levels. Part 2: Fiscal rules for sub-central governments, update of the institutional indicator

(July 2013) by Kaja Fredriksen

1070. Fiscal consolidation across government levels. Part 1: How much, what policies?

(July 2013) by Hansjörg Blöchliger

1069. Restructuring the electricity sector and promoting green growth in Japan (June 2013) by Randall S. Jones and Myungkyoo Kim

1068. Labour market policies to promote growth and social cohesion in Korea (June 2013) by Randall S. Jones and Satoshi Urasawa

1067. Education reform in Korea

(June 2013) by Randall S. Jones

1066. Belgium: enhancing the cost efficiency and flexibility of the health sector to adjust to population ageing

(June 2013) by Stéphane Sorbe

1065. Italy and the euro area crisis: securing fiscal sustainability and financial stability (June 2013) by Oliver Denk

1064. Policy implementation in Italy: legislation, public administration and the rule of law (June 2013) by Paul O’Brien

1063. Greening growth in Luxembourg

(June 2013) by Nicola Brandt

Vers une croissance plus verte en Luxembourg

(juin 2013) par Nicola Brandt

1062. The post-crisis narrowing of international imbalances - cyclical or durable?

(June 2013) by Patrice Ollivaud and Cyrille Schwellnus 
1061. Restructuring welfare spending in Slovenia

(June 2013) by Rafał Kierzenkowski

1060. The economics of civil justice: new cross-country data and empirics

by G. Palumbo; G. Giupponi; L. Nunziata and J. Mora-Sanguinetti (forthcoming)

1059. Banks' restructuring and smooth deleveraging of the private sector in Slovenia (June 2013) by Olena Havrylchyk

1058. Assessing the efficiency of welfare spending in Slovenia with data envelopment analysis (June 2013) by Matevz Hribernik and Rafał Kierzenkowski

1057. Policy determinants of school outcomes under model uncertainty: evidence from South Africa (June 2013) by Thomas Laurent, Fabrice Murtin, Geoff Barnard, Dean Janse van Rensburg, Vijay Reddy, George Frempong and Lolita Winnaar

1056. Improving education quality in South Africa

(June 2013) by Fabrice Murtin

1055. The 90\% public debt threshold: the rise and fall of a stylised fact (June 2013) by Balázs Égert

1054. Challenges to sustain Poland's growth model

(June 2013) by Balázs Égert and Rafał Kierzenkowski

1053. Reforming agriculture and promoting Japan's integration in the world economy

(May 2013) by Randall S. Jones and Shingo Kimura

1052. Inequality and poverty in the United States: public policies for inclusive growth (May 2013) by Oliver Denk, Robert Hagemann, Patrick Lenain and Valentin Somma

1051. Fiscal federalism and its impact on economic activity, public investment and the performance of educational systems

(May 2013) by Hansjörg Blöchliger, Balázs Égert and Kaja Fredriksen

1050. Restoring Japan's fiscal sustainability

(May 2013) by Randall S. Jones and Satoshi Urasawa

1049. Measuring total factor productivity at the firm level using OECD-ORBIS

(May 2013) by Peter Gal

1048. A projection method for public health and long-term care expenditures

(June 2013) by Christine de la Maisonneuve and Joaquim Oliveira Martins

1047. R\&D, patenting and growth: the role of public policy

(May 2013) by Ben Westmore

1046. Knowledge-based capital, innovation and resource allocation

(May 2013) by Dan Andrews and Chiara Criscuolo 